PAULO ARY TENDER GUIMARÃES

\title{
Cinema Digital
}

e um modelo de tecnologia alternativa de film transfer

São Paulo

2008 
PAULO ARY TENDER GUIMARÃES

Cinema Digital

e um modelo de tecnologia

alternativa de film transfer

Dissertação apresentada a Escola de Comunicação e Artes da Universidade de São Paulo para Obtenção do Título de Mestre em Ciências da Comunicação

Área de Concentração:

Estudo dos Meios e da Produção Mediática

Orientadora:

Profa. Dra. Maria Dora Genis Mourão

São Paulo

2008 
PAULO ARY TENDER GUIMARÃES

\title{
Cinema Digital
}

\author{
e um modelo de tecnologia
}

alternativa de film transfer

Dissertação apresentada a Escola de Comunicação e Artes da Universidade de São Paulo para Obtenção do Título de Mestre em Ciências da Comunicação

Área de Concentração:

Estudo dos Meios e da Produção Mediática

Orientadora:

Profa. Dra. Maria Dora Genis Mourão

São Paulo

2008 


\section{DEDICATÓRIA}

À minha mãe e minha esposa pelo incondicional apoio 


\section{AGRADECIMENTOS}

À minha orientadora, por todo o apoio e incentivo, sem os quais o trabalho não teria sido concluído. 


\section{RESUMO}

O objetivo deste trabalho é a pesquisa dos processos para realização cinematográfica, em especial os que lançam mão de tecnologia digital, e a proposição de um modelo de tecnologia alternativa para a realização de film transfer. Tomando como objeto os principais processos para realização cinematográfica, discutimos seu fluxo de trabalho, equipamentos, vantagens, desvantagens e buscamos estabelecer paralelos com as tecnologias alternativas, de maneira a acumular conhecimento para a elaboração do modelo.

O modelo de tecnologia alternativa para film transfer sugerido é o resultado da adaptação, numa premissa de baixo custo, de tecnologias de vanguarda evidenciadas nas reflexões sobre a realização.

Palavras-chave: Cinema, Cinema Digital, Tecnologia Alternativa, Intermediário Digital, Film Transfer 


\section{ABSTRACT}

This work objective is the research of the filmmaking process, particularly when utilizing digital technology, and the proposal of an alternative technology model to accomplish film transfer.

Assessing the major filmmaking processes, we discuss their workflow, equipments, advantages, disadvantages and attempt to establish parallels with alternative technologies, in a way that knowledge is amassed towards the definition of said model.

The proposed alternative technology model for film transfer results from the adaptation, restricted by a low cost premise, of high end technology ascertained during the reflections on the filmmaking process.

Keywords: Cinema, Digital Cinema, Alternative Technology, Digital intermediate, Film Transfer 


\section{SUMÁRIO}

1 INTRODUÇÃO

\section{BREVE HISTÓRIA DO DESENVOLVIMENTO DO APARATO TÉCNICO DE CAPTAÇÃO E}

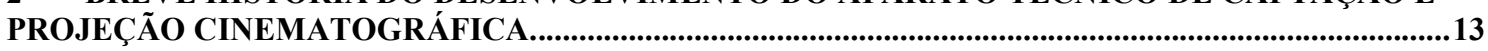

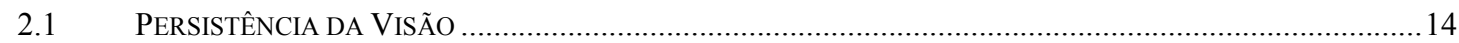

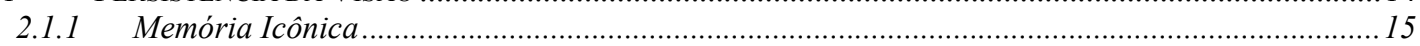

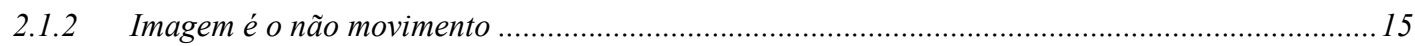

2.1.3 Ilusão de Movimento - um fenômeno fisiológico e cognitivo .................................................. 17

2.1.4 Limite Crítico da Fusão de Cintilação...................................................................................17

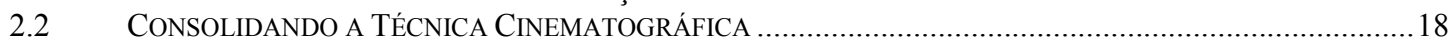

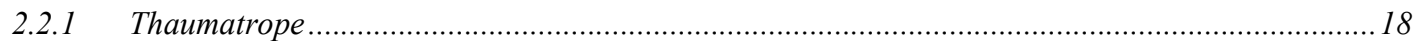

2.2.2 Heliografia - a imagem é fixada pela primeira vez ........................................................19

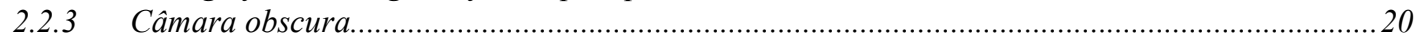

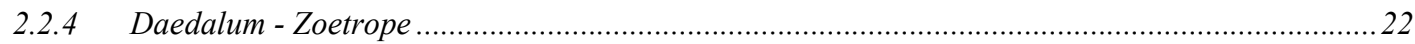

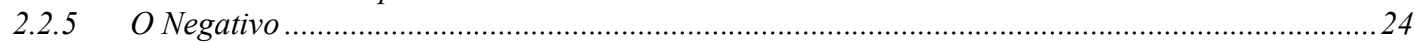

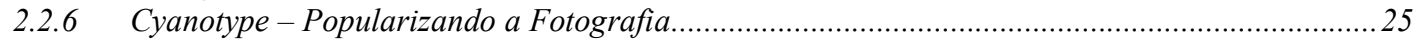

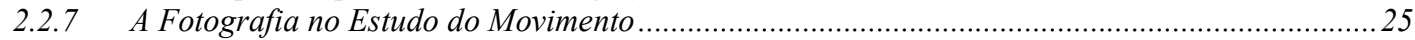

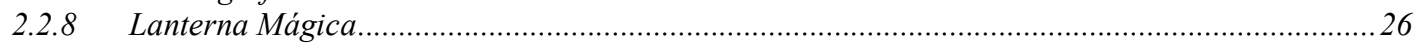

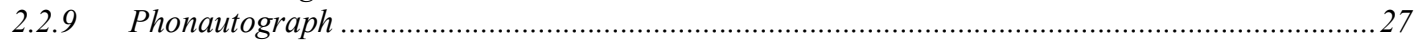

2.2.10 Manipulando a Imagem - Fabricando a Verdade ............................................................27

2.2.11 A Desarticulação Fotográfica do Movimento ...................................................................28

2.2.12 Uma Idéia de Cinema pela Tecnologia Combinada .........................................................29

2.2.13 A Gelatina de Secagem Rápida e a Película de Eastman .......................................................30

2.2.14 Quatro Patas Fora do Solo - Decomposição do Movimento...................................................31

2.2.15 Rumo ao Sincronismo da Imagem e do Som ..............................................................................32

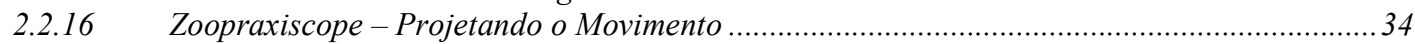

2.2.17 Tiras de Filme e uma Câmera Cinematográfica Portátil......................................................35

2.2.18 O Quinetoscópio - o Primeiro Produto da Indústria .........................................................36

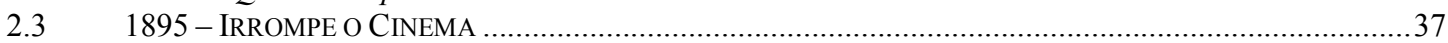

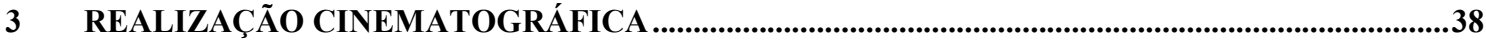

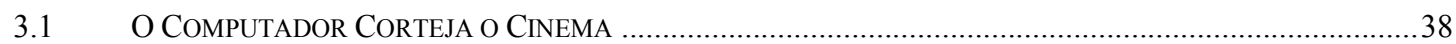

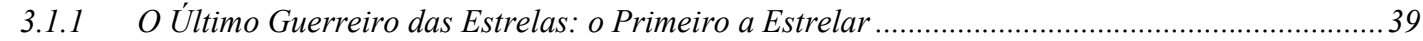

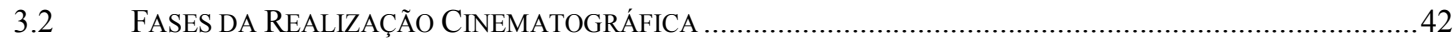

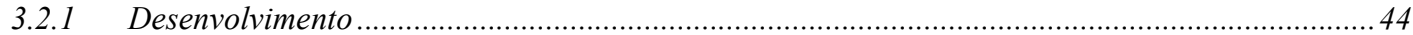

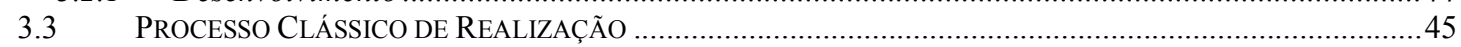

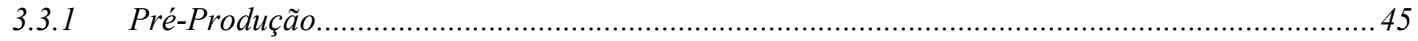

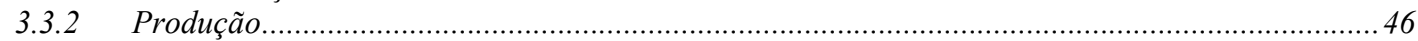

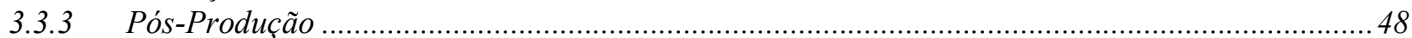

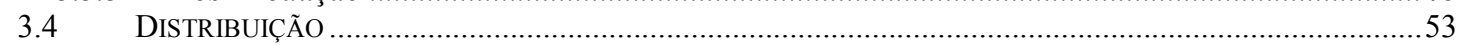

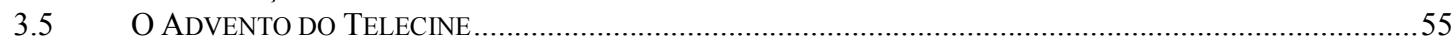

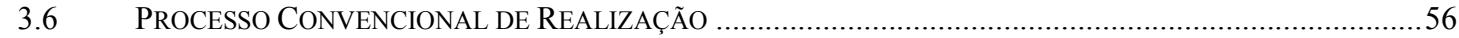

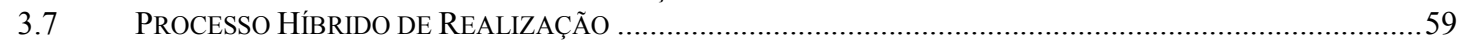

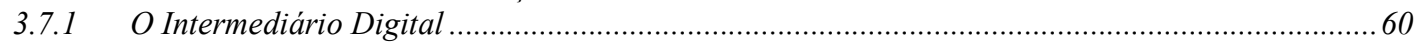

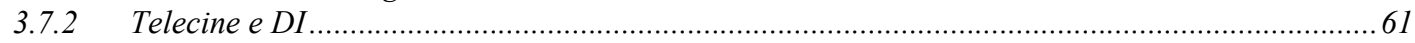

3.7.3 Processo de Pós-Produção com DI e Exibição em Filme ............................................................63

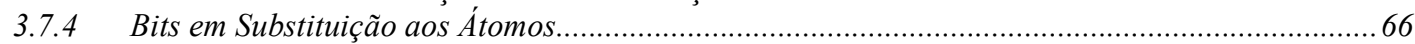

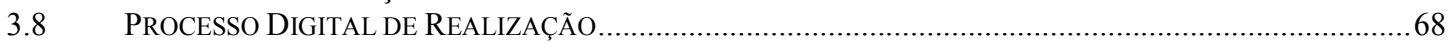

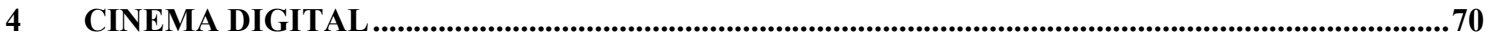

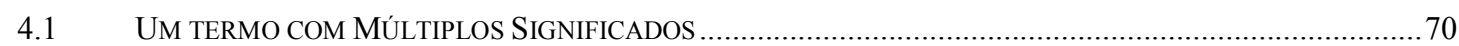

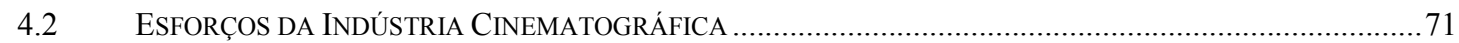




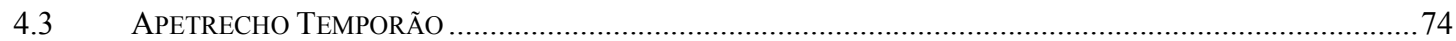

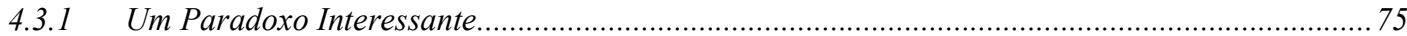

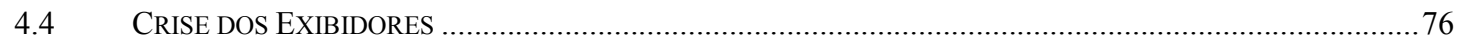

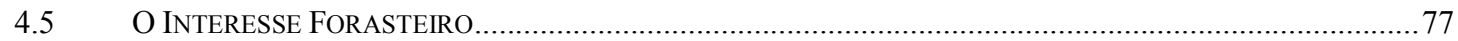

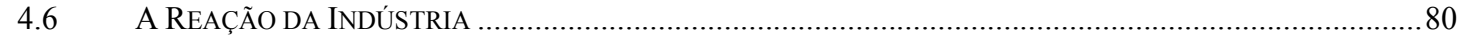

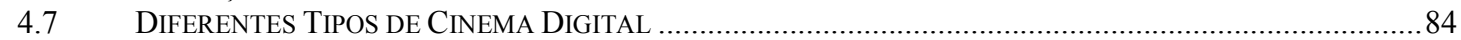

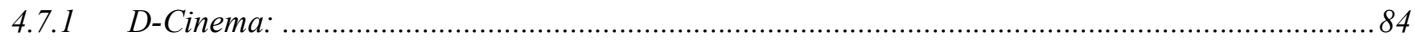

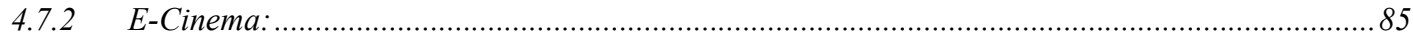

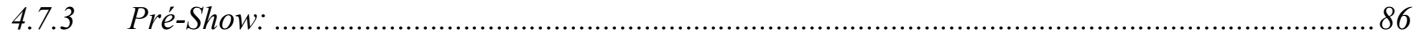

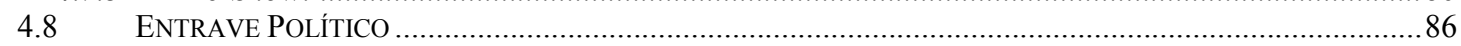

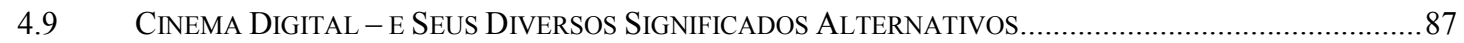

5 MODELO DE TECNOLOGIA ALTERNATIVA PARA FILM TRANSFER.................................91

AVANÇA A CONVERGÊNCIA, AJUSTA-SE O MODELO ……............................................................... 91

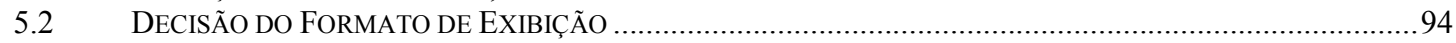

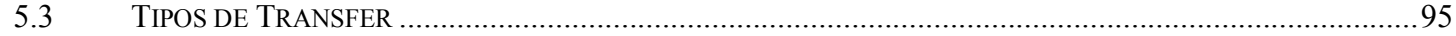

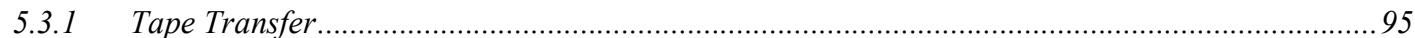

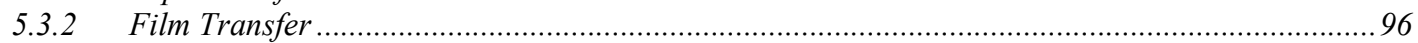

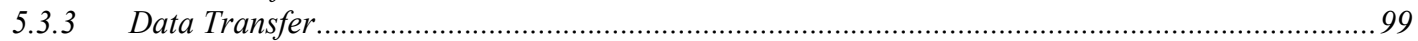

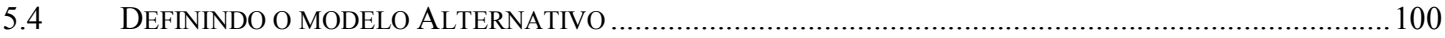

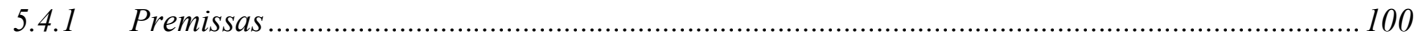

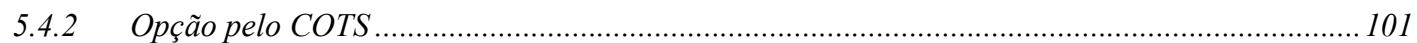

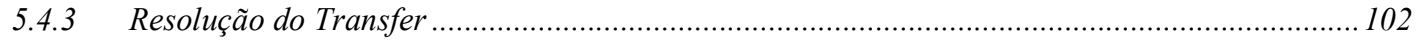

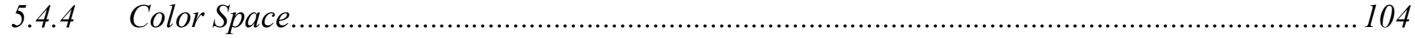

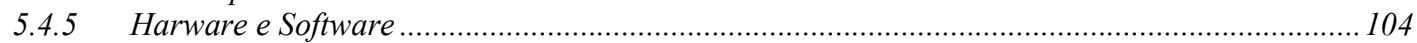

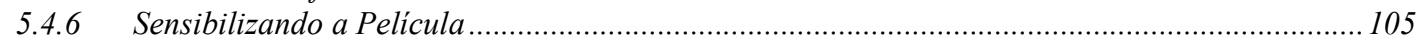

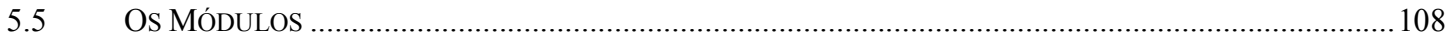

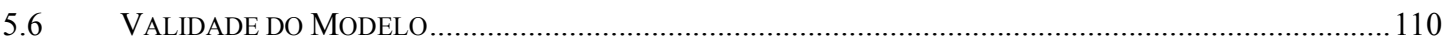

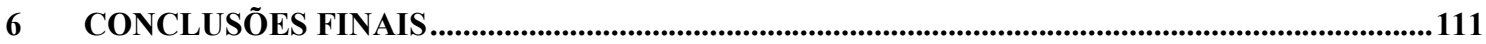

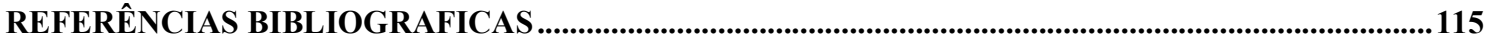

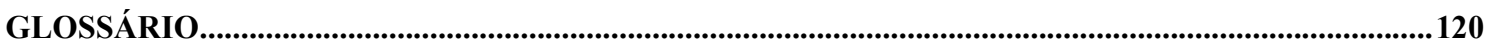




\section{Introdução}

Desde que surgiu no século XIX, o cinema veio se transformando e adaptando-se às tecnologias disponíveis, muitas destas adaptações e mudanças foram pouco perceptíveis, pois o cinema manteve inalteradas algumas de suas características mais distintas: a película e os processos de realização cinematográfica.

Esporadicamente uma ou outra evolução mais notável era divulgada, mas numa análise geral, podemos afirmar que não se percebia grandes evoluções no cinema. Durante décadas realizou-se os filmes pelo mesmo processo e exibiu-se na mesma estrutura, estabelecida em seu primórdio.

Voltaremos o olhar, temporariamente, para a pré-história do cinema para desmembrar a consolidação do filme de entretenimento no final do século XIX, início do XX, mostrá-la como um processo contínuo de evolução e que, repetidamente, os realizadores atuais inspiram-se nas conquistas e técnicas do passado.

À medida que a eletrônica foi evoluindo e se aproximando da arte de se fazer filmes, os processos tornaram-se mais dinâmicos e com eles as inovações ficaram mais evidentes. O aparecimento do vídeo iniciou um diálogo entre os equipamentos e técnicos da indústria cinematográfica, inovando consideravelmente o processo de realização clássico, pois até a década de 80 , a película era utilizada em todas as etapas da realização. $O$ advento do vídeo começou a transformar esta realidade.

O computador também se juntou ao cinema e, tal qual com o vídeo em seu tempo, alterou técnicas consagradas há décadas, transformou processos e modelos de produção. Seus efeitos, ao contrário do vídeo, podiam ser percebidos na tela e a partir disso a imagem digitais associou-se à fotoquímica.

Quando a imagem eletrônica, o vídeo, adentrou o universo dos bits onde habita o computador, as dinâmicas foram alteradas uma vez mais e os processos de realização passaram a contar com recursos digitais de captação, manipulação e 
finalização das imagens. Não só a estética refletia as mudanças, assim o fazia a indústria como um todo, refinando e ajustando seus processos.

Esta diversidade de técnicas permitiu que a película seguisse caminhos diferentes em sua realização, adotasse soluções variadas e experimentasse com a técnica. Nesta dissertação discutiremos algumas das importantes técnicas e modelos de realização cinematográfica, suas propriedades e aplicações usuais.

Ao analisarmos o processo de realização cinematográfica em suas diversas configurações, buscaremos traçar paralelos e identificar pontos positivos que possam ser utilizados na elaboração do modelo de tecnologia alternativa para o film transfer.

O cinema digital, expressão bastante usual, apresenta uma pluralidade de significados e interpretações. Esforços para defini-lo vem sendo feitos, mas não na velocidade desejada pelos realizadores. Pesquisaremos suas definições, relações, dinâmicas e refletiremos sobre seu estado de maturidade. Buscaremos utilizar tais descobertas para balizar possíveis estratégias para a elaboração do nosso aparato para transfer.

Paralelamente, analisaremos as relações dos membros da cadeia produtiva do audiovisual e suas reações ao despontar de uma tecnologia que alteraria significativamente as relações de mercado estabelecidas há décadas. $O$ cinema digital, com seu relativo menor custo, ameaça abrir as portas da indústria audiovisual para quem quer que seja.

Pesquisaremos os processos para pós-produção cinematográfica, onde o uso dos computadores e equipamentos digitais alterou significativamente sua dinâmica. Analisaremos os equipamentos disponíveis destinados ao transfer para película cinematográfica, suas vantagens e seus princípios, tentando estabelecer um paralelo com a tecnologia para desenvolvimento do nosso modelo.

Ao longo da pesquisa, apesar de considerarmos o som de vital importância para o conjunto da obra cinematográfica, concentraremos a atenção na porção visual dos filmes, pois o som é combinado com a película fotográfica, no último estágio da pós-produção, quando da geração da cópia zero. Desta forma, o 
não detalhamento das etapas da produção sonora, resulta de uma decisão de concentração na parte visual, mais próxima do objetivo, e não de esquecimento, indisponibilidade de dados ou ainda omissão preconceituosa.

Buscaremos apresentar o modelo apontando as reflexões que motivaram as definições, escolhas e conclusões colhidas nas outras partes do trabalho, pois o mesmo, tal qual a tecnologia empregada pelos inovadores dos primórdios, procura utilizar equipamentos corriqueiros, disponíveis no mercado, combiná-los e atribuirIhes outra finalidade. 


\section{Breve História do Desenvolvimento do Aparato Técnico de Captação e Projeção Cinematográfica.}

Antes que possamos discutir as transformações motivadas pelo advento do cinema digital, suas vantagens, desvantagens, características, defini-lo, ou mesmo apresentar noções sobre o processo de produção cinematográfica, consideramos fundamental retroceder e lançar rapidamente o olhar sobre seu primórdio.

Em diversos livros, reportagens e mesmo em trabalhos acadêmicos de maiores profundidade e embasamento, encontramos autores que, direta ou indiretamente, por vezes creditam inadequadamente a invenção do cinema, ou a descoberta dos fundamentos da televisão e do vídeo a um único indivíduo. Tal qual outras invenções complexas, é possível analisar a criação do cinema de uma vasta gama de ângulos distintos, não excludentes, salientando assim a esterilidade e inexatidão das tentativas de impor-Ihe um único inventor genial.

A questão de se foi Nichéphore Niepce, Mande Daguerre, Joseph Plateau, Eadweard Muybridge, Etienne Marey, George Eastman, Friese Greene, Louis Leprince, Ottomar Anschütz, Emile Reynald, os Lumière, os chineses,William Dickson para Thomas Edson ou George Méliès quem fez de fato a mais importante contribuição para o cinema, foge do nosso escopo, visto que este trabalho não pretende creditar a um único inventor o fruto do trabalho conjunto e das experimentações com as novas tecnologias de outrora, nem tampouco explorar a sua história com o objetivo de definir os verdadeiros merecedores do título de inventor.

O cinema acontece num movimento contínuo, realimentado e recursivo, de transformação, que indiscutivelmente não se limita à sistemática de produção. Se de um lado temos a evolução da tecnologia a impulsionar a linguagem cinematográfica, modificando-a à medida que novos equipamentos permitem realizações antes impossíveis, do outro, complementarmente, temos o desenvolvimento de equipamentos exclusivamente para viabilizar a obra de 
criadores visionários. Olhando para trás, percebemos que esta interdependência existe desde que a imagem cinematográfica tocou a tela pela primeira vez.

\title{
"Tudo o que pode ser projetado em uma tela pertence ao cinema"
}

\author{
Robert Desnos
}

\subsection{Persistência da Visão}

Apesar de existirem diferentes opiniões e alguns pesquisadores considerarem a teoria da persistência da visão incompleta e, em substituição, preferirem teorias de caráter mais cognitivo, em oposição ao essencialmente fisiológico para o entendimento da ilusão de movimento, tais quais as de movimentobeta e movimento-phi ${ }^{1}$, esta primeira é abrangente o suficiente para o entendimento da mecânica da visão, da ilusão do movimento e dos processos envolvidos. Independentemente dos debates conceituais sobre a efetiva causa desta percepção de movimento ao se observar, em rápida sucessão, uma seqüência de imagens estáticas que apresentem uma pequena variação de uma imagem para a próxima (tamanho, posição, cor, etc...), há consenso de que o estudo do fenômeno foi instrumental para o desenvolvimento do cinema e assim, é aqui abordado de forma compatibilizada com a essência deste trabalho. Não discutiremos suas causas, mecânica, implicações psicológicas ou questões etiológicas, pois o resultado, intrinsecamente, basta-nos como objeto.

Pela teoria da persistência da visão, o cérebro humano retém a informação visual processada, ainda por algum tempo, após o término do estímulo. Este fenômeno, produto da memória icônica, é um dos principais responsáveis pela

\footnotetext{
${ }^{1}$ Movimento-Beta e Movimento-Phi são Ilusões de percepção descritas por (WERTHEIMER, M., Experimental Studies on the Seeing of Motion, 1912). Por vezes confundidas entre si, consistem na percepção de movimento causada pela sucessão de imagens estáticas numa determinada frequência. Uma das principais diferenças é a de que o Movimento- Phi resulta de uma menor frequência de sucessão quando comparada à do Movimento-Beta. Pode-se dizer que em Beta tem-se maior percepção de movimento contínuo.
} 
ilusão de movimento quando observamos uma série de imagens exibidas rapidamente em sucessão.

\subsubsection{Memória Icônica}

É um tipo de memória visual de curto tempo, definida pelo psicólogo americano George Sperling em 1960. Através de seus experimentos, Sperling e outros forneceram evidências de um resíduo sensorial de degeneração rápida, que dura cerca de $1000 \mathrm{~ms}$ em condições favoráveis.

Estes pesquisadores Constataram que a memória icônica é extremamente frágil: o menor movimento ocular que ocorra entre o estímulo e a fixação da memória mostra-se extremamente prejudicial para sua formação. Maiores evidências desta fragilidade foram verificadas pela demonstração de que a degeneração ocorre muito mais rapidamente quando o estímulo visual é imediatamente seguido por um estímulo de fundo luminoso, em oposição ao de um fundo escuro.

\subsubsection{Imagem é o não movimento}

Rigorosamente, pode-se afirmar que a idéia de "imagem em movimento" é falaciosa em sua origem, uma vez que a imagem, per se, é uma representação da forma ou do aspecto de um ser ou objeto por meios artísticos, num determinado instante. $\mathrm{O}$ instante da captação, uma espécie de âncora no espaço-tempo, fixa no suporte o movimento do objeto, retirando-lhe a sua alma e reduzindo-o a seu aspecto.

Entendemos que a Montagem tem como sua primeira função arranjar os planos numa disposição coerente com a lógica inerente de cada filme. Não apenas uma etapa da finalização na qual ocorre a junção das partes captadas 
separadamente; trata-se de um aspecto articulatório que abarca todo o processo da realização cinematográfica, do roteiro ao produto final.

Dziga Vertov, em o "Extrato do ABC dos Kinoks", de 1929, alinhado com a "Teoria dos Intervalos" apresentada na variação do manifesto "Nós", de 1919, abordando as correlações de imagem, escreveu:

A escolha do Cine-Olho exige que o filme seja construído sobre os intervalos, isto é, sobre o movimento entre as imagens. Sobre a correlação visual das imagens, uma em relação às outras. Sobre a transição de um impulso visual ao seguinte.

A progressão entre as imagens (intervalo visual, correlação das imagens) é (para o Cine-Olho) uma unidade complexa.

Ela é formulada pela soma de diversas correlações, sendo que as principais são: ${ }^{2}$

- correlação dos planos (grandes, pequenos, etc...),

- correlação dos enquadramentos,

- correlação dos movimentos no interior da imagem,

- correlação das luzes, sombras,

- correlação das velocidades de filmagem.

Sem violentar demais os escritos de Vertov, cabe sugerir o acréscimo de uma outra correlação que, por ser a mais básica de todas, talvez seja considerada natural, própria:

\section{- correlação dos quadros.}

Consideramos ser exatamente esta tão importante e sutil correlação a responsável pela ilusão de movimento.

Quando as variações de um quadro para o outro são adequadas, o espectador é capaz de fazer, mesmo sem se dar conta, esta última correlação e conseqüentemente entender "movimento" observando imagens estáticas.

\footnotetext{
${ }^{2}$ XAVIER, I. A Experiência do Cinema, antologia. Rio de Janeiro: Edições Graal, 1983, pg. 264 - do original francês: Articles, Journaux, Projets, Paris, Union Générale d'Éditions, 1972.
} 


\subsubsection{Ilusão de Movimento - um fenômeno fisiológico e cognitivo}

Considerando que o fenômeno da ilusão de movimento, apesar de intrinsecamente ligado à fisiologia da visão humana, encontra-se melhor fundamentado nas teorias cognitivas, podemos sugerir que a sensação de movimento produzida pela exposição rápida de imagens seqüenciais, tais quais no cinema, é uma primeira forma de Montagem que deve acontecer a cada vez que se assiste a um filme.

A imagem em movimento propriamente não existe. É também o espectador que a interpreta neste estado - atribuindo-lhe esta qualidade. Analisando as variações na imagem e comparando-as com suas próprias referências no espaçotempo, o espectador, sem raciocinar, interpreta a seqüência de imagens e capta um significado.

\subsubsection{Limite Crítico da Fusão de Cintilação}

Apesar de existirem variações fisiológicas pessoais que alteram o limite de cada indivíduo, quando a freqüência de renovação das imagens é superior ao "Limite Crítico da Fusão de Cintilação" ( Critical flicker fusion threshold (CFFT) ), há universalidade na interpretação do estado de movimento.

Critical Flicker Fusion Threshold (CFFT) is the lowest level of continuous flicker that is perceived as a steady source of light and has historically been shown to be remarkably stable

Limite Crítico da Fusão de Cintilação (CFFT) é o menor nível de cintilação contínua que é percebido como uma fonte de luz estável e historicamente tem se mostrado consideravelmente estável (Tradução Nossa) de HOLLOWAY, S. R.; NÁÑEZ Sr, J. E.; SEITZ, A. R.; WATANABE, T. The Relationship Between Flicker Fusion and Subliminally Induced Neural 
Plasticity, 2005, Journal of Vision, 5(12), 14a Disponível em: http://journalofvision.org/5/12/14

Presentemente, considera-se o limite crítico da fusão de cintilação entre 16 e $20 \mathrm{hz}$.

Similarmente aos ontem ignorados quarks que constroem os átomos, os quadros são unidos primeiramente pelo espectador, numa espécie de primordial "sutura" discreta, para construir os planos. De lá, valendo-se destes planos como unidades, segue a montagem.

\subsection{Consolidando a Técnica Cinematográfica}

Os esforços de vários pesquisadores, muitas vezes atuando em áreas diferentes que em algum momento aproximaram-se, contribuíram para o desenvolvimento do aparato técnico e a descoberta dos princípios para a implantação do cinema, são trajetórias progressivas incrementais ou inicialmente paralelas que, reorientadas, chegaram a uma intersecção. Abordaremos alguns dos passos mais significativos para o amadurecimento da tecnologia cinematográfica.

\subsubsection{Thaumatrope}

Roget e Paris forneceram contribuições que se fundem e são constantemente confundidas. Em várias fontes, aparecem as ações de um creditadas ao outro. Há trabalhos acadêmicos que citam Roget sozinho como o descobridor dos fundamentos do cinema, da televisão e do vídeo. Apenas este aspecto da história seria suficiente para gerar o objeto de pesquisa de outro estudo. Contudo, dados o escopo deste trabalho, a contrariedade das fontes, diversidade de informações e o objetivo desta passagem, tomaremos a versão mais difundida, sem 
prejuízo de exatidão ao não desconsiderarmos a possibilidade do aparecimento de novas informações definidoras.
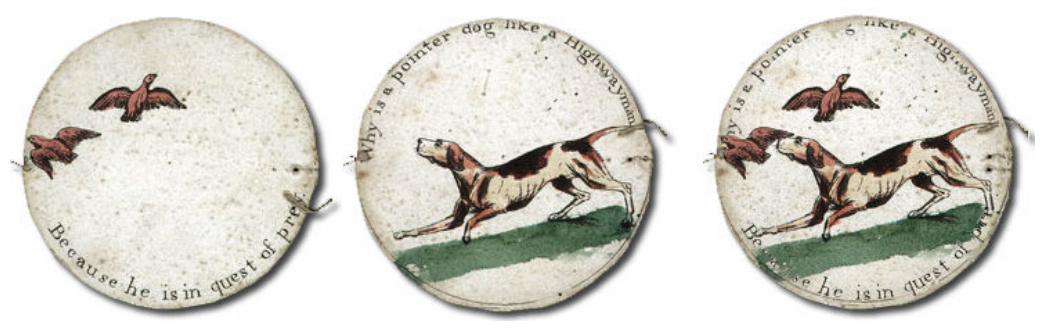

Figura 2.1 - Thaumatrope de 1825

Em 1824, Peter Roget expôs ao Royal College of Physicians a persistência da visão, tema de seu trabalho. Contemporaneamente, John Ayrton Paris inventou o thaumatrope, um disco contendo uma imagem em cada face e um cordão de cada lado prolongando seu diâmetro. Quando os cordões eram torcidos, o disco girava rapidamente e em suas faces viam-se as duas imagens combinadas. (Algumas fontes citam Roget como inventor do thaumatrope. Não há, tampouco, consenso quanto à data da invenção, se em 1824 ou 1825).

\subsubsection{Heliografia - a imagem é fixada pela primeira vez}

Joseph Nicephore Niepce, em 1826, deu o passo que é reconhecido como um dos mais significativos para a evolução do cinema e que o confirma muito à frente de outros de seu tempo: a fixação permanente de uma imagem. Até então, mesmo com o conhecimento e emprego de substâncias reagentes à luz, sucesso na cessação do processo e a posterior fixação da imagem não havia ocorrido em nenhum experimento. 


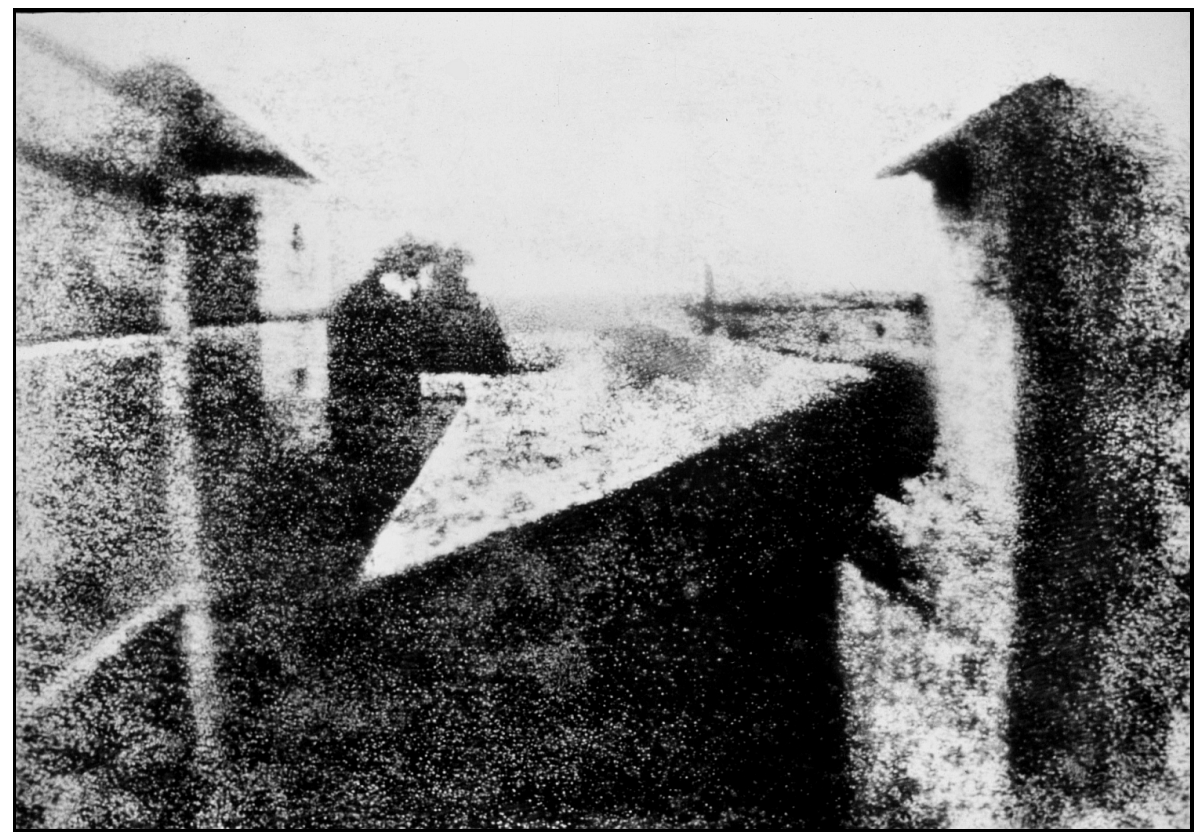

Figura 2.2 - Heliografia de 1826, “View from the Window at le Gras”

Valendo-se de uma câmara obscura e de uma placa de peltre sensibilizada com betume da judea, Niepce criou o que batizou de heliografia. $O$ primeiro resultado divulgado de seu experimento, a fotografia rudimentar "View From The Window At Le Gras", ainda existe como parte do acervo da coleção Gernsheim no Centro de Pesquisas de Humanidades Harry Ransom da Universidade do Texas, em Austin.

\subsubsection{Câmara obscura}

Um aparato ótico outrora utilizado no desenho para garantir que as perspectivas e proporções fossem mais realistas; geralmente um cômodo onde se encerrava o artista. As imagens que passavam por um orifício na parede eram refletidas em uma outra parede escura, ou após passar por um espelho, atingiam uma folha de papel para serem copiadas. Este artefato, que fora empregado desde a 
antiguidade, aparece pela primeira vez registrado, no século $\mathrm{XI}$, nos escritos de Abu Ali Al-Hazen, cientista muçulmano.

Posteriormente o renascentista Leonardo DaVinci descreve uma câmara obscura em seu Atlanticus Codex e Johann Zahn, em seu "Oculus Artificialis Teledioptricus Sive Telescopium”, de 1685, apresenta diversas descrições, planos, diagramas de câmaras obscuras e de Lanternas Mágicas.

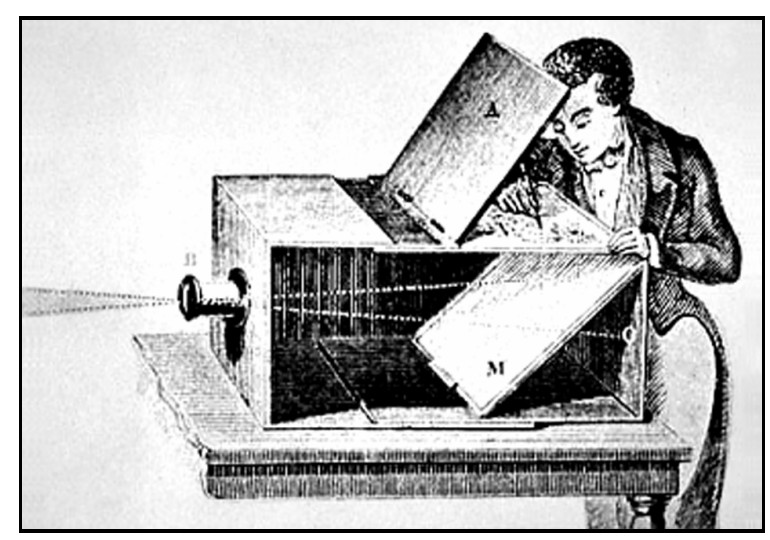

Figura 2.3 - llustração de 1855 Câmara Obscura Portátil

No século XIX, não era incomum o emprego da câmara obscura portátil. Tratava-se, geralmente, de uma caixa de madeira com uma lente instalada no orifício. Esta lente foi a responsável pela redução do tamanho da câmara e conseqüente portabilidade. Adicionalmente, permitia ajustar a nitidez da imagem projetada no papel.

A invenção da câmara obscura é mais uma destas questões enigmáticas que, dependendo da fonte consultada, compromete o entendimento em um sentido. A descrição da câmara obscura ( Enciclopédia Focal de Fotografia..., 1975, pág. 198) compreende o seguinte trecho:

A câmera fotográfica deriva diretamente da câmara obscura. (...) Sua invenção tem sido erroneamente atribuída, por vários escritores, a Roger Bacon, Alberti, Leonardo da Vinci e Giovanni Battista Porta. Na realidade, foi descoberta pelo árabe Alhazen antes de 1039, ou seja, uns duzentos e cinqüenta anos antes de Bacon. Posto que o relato de Alhazen não se 
apresenta como um fato novo, pode-se supor que este conhecimento era comum entre os cientistas árabes.

Também explorando o fenômeno da persistência da visão, em 1831, simultaneamente, o belga Joseph Plateau e o austríaco Simon von Stampfer criaram o phenakistiscope, ou phenakistoscope - um ou dois discos com frestas que, ao girarem, mostravam desenhos seqüenciais e, pela persistência da visão, produziam a ilusão de movimento.

\subsubsection{Daedalum - Zoetrope}

Aperfeiçoando o phenakistoscope, em 1834, George Horner criou o "daedalum" ou "daedatelum" - um cilindro com frestas por onde se observavam imagens, na época desenhos, e que ao girar produzia a ilusão de movimento. Um grande passo para desenvolver a mecânica de um processo fundamental para o desenvolvimento da técnica. Esta invenção, ao ser levada para os Estados Unidos, foi rebatizada com o nome que a popularizou: Zoetrope.

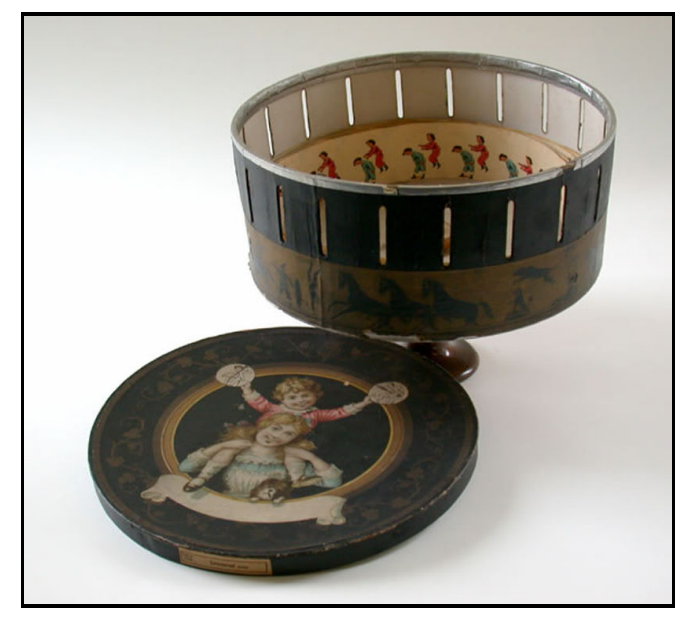

Figura 2.4 - Zoetrope Alemão de Papel e Madeira - séc. XIX 


\subsubsection{Zoetrope e Submedia: nova tecnologia com uns 165 anos}

Reforçando a idéia de que a evolução da tecnologia cinematográfica ocorre de maneira realimentada e contínua, tomemos o caso da Submedia, com seu "inovador" produto patenteado por Spodek.

Um cilindro com frestas verticais, o daedalum ou zoetrope, que hoje pode ser visto nos festivais de animação numa espécie de exibição de peça ancestral de animação, em 1980 serviu de inspiração para o cineasta independente Bill Brand, que instalou um enorme Zoetrope linear numa plataforma sem uso do metrô de New York, batizando-o como "Masstransiscope".

A idéia inovadora de transformar o cilindro num painel linear e, mais vanguardista ainda, a proposta de ao invés de girar um cilindro, deslocar o espectador paralelamente ao painel linear, de modo que seu olhar percorresse as frestas, aproximou Brand dos artistas e inventores que passo a passo criaram a técnica cinematográfica clássica.

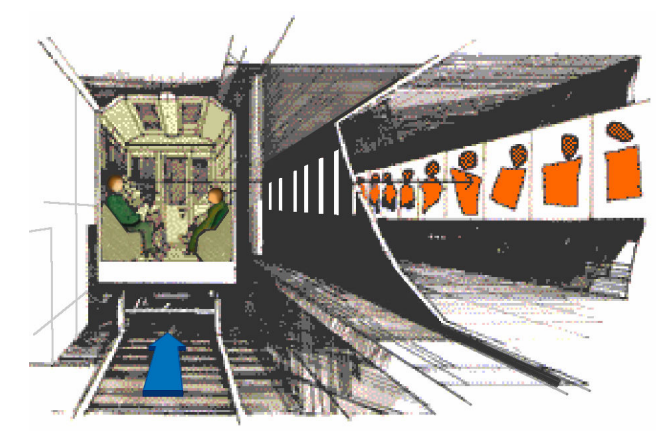

Figura 2.5 - Masstransiscope de Bill Brand

Por mais de duas décadas, milhões de passageiros do metrô de New York, ao se deslocarem de trem pela plataforma da estação Myrtle Avenue, puderam ver as imagens de 227 painéis em movimento do Masstransiscope de Brand.

De 1996 a 1999, tal qual Edson e Willian Lincoln em sua época, o americano Josh Spodek, desenvolveu sobre o modelo do Masstransiscope e do Daedalum, patenteando um modelo funcional de Zoetrope linear que, já instalado 
em diversos metrôs do mundo, foi repetidamente citado como uma das mídias mais revolucionárias. Por transformar este aparato ancestral e a "mera" arte em um modelo de negócio rentável, em 2003 Spodek foi citado na reportagem da Esquire: "Best and Brightest": People Revolutionizing The World, Esquire Names America's, como o pioneiro da propaganda de próxima geração.

\subsubsection{O Negativo}

William Henry Fox Talbot, em 1835, deu novo impulso à fotografia ao desenvolver um negativo mais próximo do de papel e registrar nele, também com uma câmara obscura, a imagem de sua janela - esta foto encontra-se no Museu Nacional de Fotografia, Cinema e Televisão, em Bradford - Reino Unido. Nos anos seguintes, em especial de 1844 a 1860, colaborou em muito para avançar a técnica da fotografia. Sua pesquisa sobre o dicromato de potássio e como endurecia a gelatina coloidal proporcionalmente à quantidade de luz recebida foi subsidiária para o avanço do processo fotográfico.

Daguerre, também em 1835, obteve sucesso ao tentar produzir uma primeira imagem fixada permanentemente numa placa de iodeto de prata exposta ao vapor de mercúrio; sucesso este, conclusão de uma parceria de trabalho firmada seis anos antes com Niepce, que falecera em 1833, sem poder apreciar os resultados concretos do desenvolvimento de seu trabalho.

\subsubsection{Talbot e Daguerre - Descobertas Simultâneas}

Quatro anos depois, em 1839, com seus trabalhos bem mais maduros, Talbot e Daguerre declararam à comunidade científica e à sociedade que, individualmente e de maneira independente, desenvolveram processos para fixar imagens capturadas em uma câmara obscura. O processo de Daguerre, apelidado de daguerreótipo ou fotografia recebeu maior atenção. Com a compra da patente 
pelo governo francês e subseqüente liberação dos direitos de uso, a invenção espalhou-se mundo afora e pode-se dizer que suplantou a de Talbot. Há, contudo, variadas opiniões sobre o melhor sistema e ainda propriedade do inventor, especialmente quando autores adotam um viés partidário ou nacionalista.

\subsubsection{Cyanotype - Popularizando a Fotografia}

Pouco depois John Frederick William Herschel desenvolveu um processo utilizando ferrocianeto de potássio, o Cyanotype, que permitiu a fixação de imagens a custo muito baixo. De maneira análoga ao que acontece com as novas tecnologias hodiernas, o processo primeiro apenas existiu em condições bastante controladas, depois se ramificou em versões mais práticas - técnicas alternativas baseadas no mesmo princípio - e posteriormente popularizou-se com a evolução da tecnologia e redução do custo. As primeiras imagens precisavam de cerca de oito horas de exposição e as baseadas no ferrocianeto de potássio menos de noventa segundos, por um custo vinte e cinco vezes menor.

\subsubsection{A Fotografia no Estudo do Movimento}

Joseph A. Ferdinand Plateau começou a empregar e difundir a idéia de fotografias para o estudo do movimento, em substituição aos desenhos utilizados até então, em 1848; no mesmo ano em que Frederick Archer tornou viável o processo de colóide úmido.

Por volta de 1855, graças aos avanços da técnica de produção de negativos, redução do custo e tempo de fixação menor, a fotografia começou a se espalhar de maneira significativa. As exibições públicas de Lanterna Mágica, outrora apresentando exclusivamente desenhos feitos à mão, passaram a conter "photographs": exibições contendo material fotográfico, de caráter informativo em contrapartida ao destinado meramente ao entretenimento. 


\subsubsection{Lanterna Mágica}

A Lanterna Mágica é considerada por muitos uma ancestral do projetor de slides ou do retroprojetor. Uma lamparina a óleo projetava na tela, através de uma lente, desenhos pintados à mão em uma placa de vidro. Algumas possuíam placas com secções extras que, ao serem deslocadas, resultavam no movimento das imagens, assombrando a platéia.

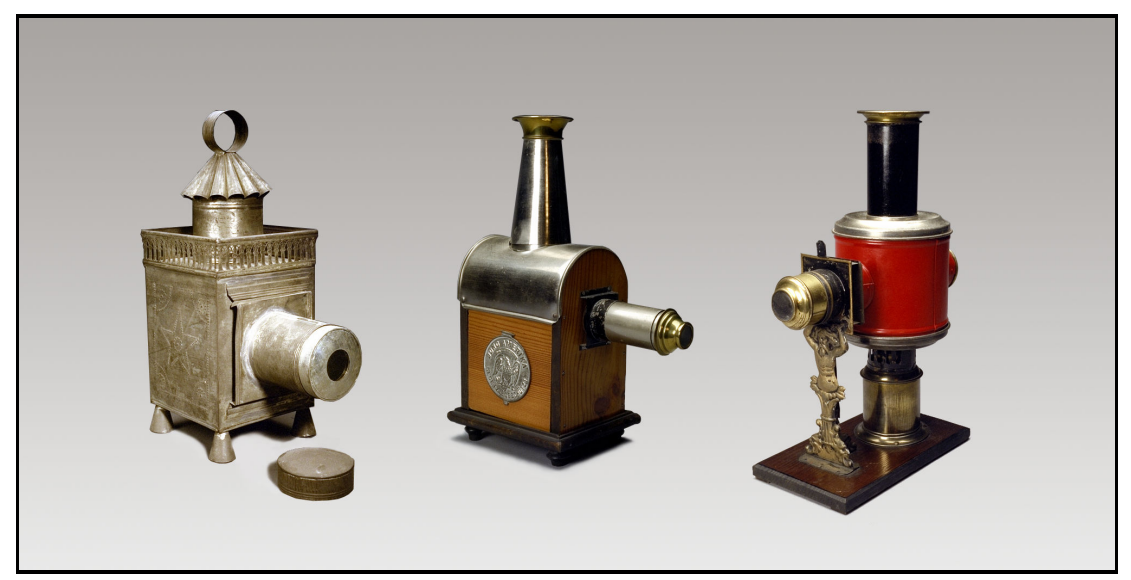

Figura 2.6 - Lanternas Mágicas: Gothic (1830), Young Amerika (1890) e Atlas (1880)

No século XIX, várias trupes itinerantes percorriam a Europa, principalmente no Reino Unido, apresentando seus espetáculos. Muitas até possuíam vários repertórios, mas foi posteriormente, com os avanços tecnológicos e desenvolvimento da técnica de reprodução dos slides que as Lanternas Mágicas ganharam difusão muito maior.

Com o desenvolvimento da fotografia, a variedade dos slides apresentados cresceu significativamente. Exibiam-se imagens de terras estrangeiras, personalidades, monumentos e muitos outros assuntos alheios ao mundo do cidadão comum. 


\subsubsection{Phonautograph}

Edouard-Leon Scott recebeu em 1857 a patente por seu phonautograph, uma invenção engenhosa, que inspirada na estrutura do ouvido humano, gravava sons num cilindro especialmente preparado. O som captado por uma corneta (horn) fazia vibrar um diafragma em sua ponta, que transmitia movimento às cerdas de porco a ele conectadas. Estas cerdas, ao se movimentarem, gravavam num cilindro rotativo coberto de fuligem a vibração sonora captada pelo aparelho. O phonoautograph não reproduzia o som gravado, apenas registrava-o e foi bastante empregado para o estudo das ondas sonoras.

Vinte anos depois, Edson receberia a patente por seu phonograph, que, "fortemente inspirado" no trabalho de seu precursor Scout, aparece desacertadamente em diversos trabalhos como o primeiro aparelho a gravar o som. Pode-se afirmar que o fonógrafo de Edson foi o primeiro aparelho, manufaturado ${ }^{3}$, a gravar e reproduzir o som. Contudo, o Phonoautograph de Scout antecedeu o phonograph de Edson em algumas décadas.

\subsubsection{Manipulando a Imagem - Fabricando a Verdade}

No ano de 1858 , o mesmo ano em que o movimento natural passou a ser registrado de maneira mais eficiente ${ }^{4}$, Henry Peach Robinson produziu sua polêmica foto "Fading Away". Esta primeira fotomontagem da história, mostrava o que

\footnotetext{
${ }^{3}$ Faz-se necessário o emprego do termo manufaturado, pois Charles Cros, um inventor e poeta francês, registrou o Paleofone um aparelho gravador-reprodutor de sons junto à Academia de Ciências de Paris, pelo menos sete meses antes de Edson anunciar ou demonstrar seu fonógrafo. Todavia, o Paleofone não chegou a ser produzido e comercializado.

4 Face à baixa sensibilidade dos negativos ou placas, o tempo necessário para a correta exposição de uma imagem era mais alto que o requerido para registrar pessoas movendo-se naturalmente. Uma foto de uma rua repleta de transeuntes, registraria apenas os prédios e as calçadas vazias. Desta forma, era prática na época contratar artistas para pintar, sobre as fotos, as pessoas caminhando nas calçadas, ocupando-se das atividades urbanas, de maneira a conferir um tom mais humano à fotografia. Posteriormente, quando o tempo de exposição necessário tornou-se menor, mas ainda muito alto para alguém permanecer absolutamente imóvel, foram criados aparatos imobilizadores que, longe do olho da câmara, aprisionavam aparafusando o sujeito modelo na posição necessária, permitindo a produção de retratos pessoais.
} 
aparentava ser uma garota definhada deitada em seu leito, à beira da morte, rodeada por sua família. Execrada pela sociedade por tratar-se de uma foto de péssimo gosto, que não respeitava o sofrimento alheio, "fading away", valendo-se da sobreposição de cinco negativos, figurou como a primeira foto a representar uma situação supostamente natural ou a primeira fotomontagem.

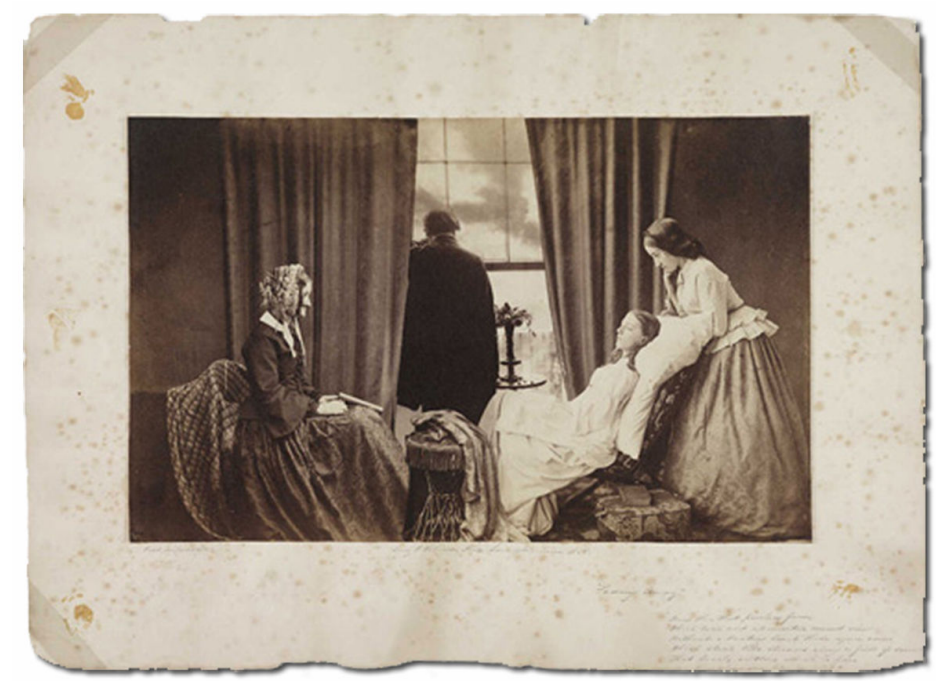

Figura 2.7 - Fotografia de 1858, Fading Away

\subsubsection{A Desarticulação Fotográfica do Movimento}

Oliver Wendall Holmes, em 1861, num trabalho pioneiro, analisou fotos de transeuntes nas calçadas, caminhando, flagrados no meio do passo, correndo, etc... Deste esquadrinhamento do movimento, produziu uma espécie de "animator's sequence chart" ${ }^{\prime \prime}$ com movimentos detalhados dos joelhos, pés e tornozelos. Este trabalho foi, não só de ótima valia ao subsidiar o entendimento da dinâmica do movimento e para o aperfeiçoamento de membros artificiais para os mutilados de guerra, mas também concretizou o uso da fotografia para a decomposição e análise do movimento.

\footnotetext{
5 O animator's sequence chart é uma ferramenta de animação, um documento, onde se registra vários instantes seqüenciais de uma mesma ação. Uma decomposição do movimento para que se possa avaliar a dinâmica do movimento.
} 


\subsubsection{Uma Idéia de Cinema pela Tecnologia Combinada}

Levando-se em conta o negativo, ainda que primário, o fonógrafo e a Lanterna Mágica, pouco depois da metade do século XIX, a tecnologia vigente já permitia o registro fotográfico do movimento, a projeção de fotografias, a utilização de negativos para a projeção, a produção da ilusão de movimento, a gravação mecânica de sons e até rudimentares fotos coloridas.

Restava encontrar uma maneira de combinar estas tecnologias distintas e criar os elos de ligação para que fosse viabilizada de maneira integrada a projeção de imagens e a reprodução sonora. Diversos pesquisadores trabalhavam com este objetivo, sendo que o primeiro registro de um passo significativo, que mostrasse sinal de desenvolvimento foi dado pelo criador do processo de colorir fotografias, Louis Arthur Ducos Du Hauron.

\subsubsection{A Patente de Hauron}

Hauron, o pioneiro da fotografia colorida, em uma patente de 1864, escreveu:

My invention consists in substituting rapidly and without confusion to the eye not only of an individual, but when so desired of a whole assemblage, the enlarged images of a great number of pictures when taken instantaneously and successively at very short intervals.... The observer will believe that he sees only one image, which changes gradually by reason of the successive changes of form and position of the objects which occur from one picture to the other. Even supposing that there be a slight interval of time during which the same object was not shown, the persistence of the luminous impression upon the eye will fill this gap. There will be as it were a living representation of nature and ... the same scene will be reproduced upon the screen with the same degree of animation.... By means of my apparatus I am enabled especially to reproduce the passing of a procession, a review of military 
manoeuvres, the movements of a battle, a public fete, a theatrical scene, the evolution or the dances of one or of several persons, the changing expression of countenance, or, if one desires, the grimaces of a human face; a marine view, the motion of waves, the passage of clouds in a stormy sky, particularly in a mountainous country, the eruption of a volcano, etc.

Minha invenção consiste em substituir rapidamente e sem confusão para o olho, não só de um indivíduo, mas quando também desejado, para toda uma aglomeração, as imagens ampliadas de um grande número de fotografias tiradas instantânea e sucessivamente em intervalos muito curtos... O observador acreditará que vê apenas uma imagem que muda gradualmente, pelas mudanças sucessivas de forma e posição dos objetos que ocorrem de um quadro para o outro. Mesmo considerando que há um pequeno intervalo de tempo em que o mesmo objeto não foi exibido, a persistência da impressão luminosa na visão preencherá esta lacuna... a mesma cena será reproduzida na tela com o mesmo grau de animação... Por intermédio do meu aparato posso reproduzir especialmente o passar de uma procissão, a revista de manobras militares, os movimentos de uma batalha, uma festa pública, uma cena teatral, as evoluções ou danças de uma pessoa ou grupo de pessoas, a expressão mutável de austeridade, ou, se desejado, as caretas de uma face humana; uma vista marítima, o movimento das ondas, a passagem de nuvens em um céu tempestuoso, particularmente em um país montanhoso, a erupção de um vulcão, etc. (nossa tradução)

\subsubsection{A Gelatina de Secagem Rápida e a Película de Eastman}

Enquanto em 1868, Eadweard Muybridge, na época "residente" da Califórnia, incursionava pelo interior e firmava-se como fotógrafo, trabalhando com colódio-úmido (wet-collodion) e sob o pseudônimo de Helios the flying camera (Helios a câmera voadora / Helios - Sol), Richard Maddox criava outro processo, o da gelatina de secagem rápida. Neste processo, a solução sensível não perdia suas propriedades de reação à luz quando seca. Ficava protegida pela gelatina e, em comparação ao colódio-úmido, era consideravelmente mais prática e rápida. 
George Eastman, insatisfeito com a fragilidade do suporte de vidro e do enorme trabalho envolvido no processo de preparação das chapas de colódio úmido ${ }^{6}$, concentrou esforços em desenvolver uma base mais adequada que as chapas de vidro. Como resultado de sua pesquisa com a recém criada gelatina, encontrou uma saída constituída por uma película de nitrocelulose com emulsão de brometo de prata preservada em gelatina seca. Esta possuía a boa resolução e sensibilidade das chapas de vidro, sem contudo apresentar problemas semelhantes de fragilidade. Nem era tão trabalhosa e limitante quanto o processo de colódio úmido. Mais interessante ainda, oferecia a mesma flexibilidade e praticidade dos negativos de papel. Uma combinação vencedora, que muito colaborou para difundir a fotografia e, conseqüentemente, o cinema.

\subsubsection{Quatro Patas Fora do Solo - Decomposição do Movimento}

Muybridge, financiado por Leland Stanford, após ter falhado numa primeira tentativa cinco anos antes, finalmente provou fotograficamente que um cavalo ao galopar levantava, em um determinado instante, todas as quatro patas do solo. Para tal, utilizou uma bateria de 12 câmeras acionadas mecanicamente por fios tencionados pelo cavalo. O espectador, ao observar as imagens num daedalum, via um cavalo a galopar. A partir daí, resolveu perseguir o novo empreendimento cientifico da época, o estudo fotográfico de animais em movimento.

O filme The matrix, recebeu o Oscar de efeitos especiais em 2000 e inúmeros elogios pelas "incríveis idéias originais" dos efeitos visuais. Curiosamente, seu efeito mais notório, apelidado de bullet-time - replicado em inúmeros outros filmes e jogos - utilizou exatamente a técnica de Muybridge para fotografar o cavalo de corrida. Neste efeito viu-se, numa espécie de câmera-lenta extrema, o tempo quase estagnar quando o personagem Neo esquivou-se dos projéteis disparados contra ele, enquanto a câmera orbitava à sua volta. Várias câmeras fotográficas

\footnotetext{
${ }^{6}$ Colódio-úmido: Este processo, desenvolvido por Frederick Archer em 1848, empregava o colódio - composto de éter, álcool e uma solução de nitrato de celulose para aderir nitrato de prata fotossensível a uma chapa de vidro. Constituía uma espécie de negativo de vidro. Esta chapa, por precisar ser exposta ainda úmida, recebeu o nome de processo de colódio úmido - wet-collodion - e dominou a fotografia por mais de duas décadas. A revelação precisava ocorrer logo após a exposição.
} 
acionadas em seqüência para depois recompor o movimento: uma idéia inovadora com pouco mais de 120 anos.

Em 1878, as revistas Scientific American e La Nature publicaram algumas fotos de Muybridge que os leitores poderiam colocar dentro de seus zoetropes para assisti-las em movimento.

Étienne-Jules Marey, inspirado pelos resultados do trabalho fotográfico de Muybridge, como também o de Holmes, valendo-se do desenvolvimento da sensibilidade dos negativos com o conseqüente aumento de velocidade, adiantou mais a utilização de fotografias para análise de movimento. Na época, estudava o vôo de insetos e pássaros e concebeu um processo para registrar uma seqüência de imagens em uma mesma chapa, utilizando uma única lente.

\subsubsection{Rumo ao Sincronismo da Imagem e do Som}

Edson apresentou seu fonógrafo em 1877-78, que, lembrando em muito o phonautograph de Edouard Scott, valia-se de um diafragma que ao mover-se gravava essas alterações na superfície de um cilindro de estanho. A inovação do fonógrafo foi, ao utilizar o cilindro metálico, permitir a reprodução dos movimentos originais do diafragma e conseqüentemente o som.

Charles-Emile Reynaud aperfeiçoou o daedalum, zoetrope, de Horner e criou o praxinoscope, ao adicionar espelhos que refletiriam as imagens no interior do cilindro. O segmento da reprodução da imagem captada ganhava atenção e boa parte dos inventores de plantão direcionava esforços para conseguir um processo funcional. 


\subsubsection{A Visão do Fonógrafo Combinado ao Kinesigraph}

Wordsworth Donisthorpe, inspirado no mecanismo criado por seu pai, também inventor, para automatizar o pente das máquinas de tear, descreveu uma câmera para expor chapas em rápida sucessão e que posteriormente seriam projetadas na mesma velocidade. Seu "kinesigraph" nunca chegou a funcionar a contento. Contudo, apesar de na prática ter fracassado, considera-se diferencial sua participação pela divulgação da idéia de combinar tal aparelho com o recém lançado fonógrafo, registrada no exemplar da Nature $^{7}$ de Janeiro de 1878.

By combining the phonograph with the Kinesigraph I will undertake not only to produce a talking picture of Mr. Gladstone which, with motionless lips and unchanged expression shall positively recite his latest anti-Turkish speech in his own voice and tone. Not only this, but the life-size photograph itself shall move and gesticulate precisely as he did when making the speech, the words and gestures corresponding as in real life. Surely this is an advance upon the conception of the Scientific American! I think it will be admitted that by this means a drama acted by daylight or magnesium light may be recorded and reacted on the screen or sheet of a magic lantern, and with the assistance of the phonograph the dialogues may be repeated in the very voices of the actors. When this is actually accomplished the photography of colors will alone be wanting to render the representation absolutely complete, and for this we shall not, I trust, have long to wait.

Ao combinar o phonograph com o kinesigraph, garantirei não só produzir uma imagem falante do Sr. Gladstone que, com lábios imóveis e expressão imutável certamente recitará seu mais recente discurso "anti-turco" com sua própria voz e tom. Não só isso, mas a própria fotografia em tamanho real mover-se-á e gesticulará exatamente como este o fez ao proferir o discurso, as palavras e gestos correspondendo aos da vida real. Certamente este é um avanço sobre a concepção da Scientific American! Considero que se admitirá que, por este meio, um "drama" representado à luz do dia ou de magnésio pode ser gravado e "re-encenado" na tela ou lençol de uma lanterna mágica e, com a ajuda do phonograph, os diálogos podem ser repetidos nas próprias vozes dos atores. Quando de fato isto for conseguido, apenas a fotografia em cores carecerá para tornar a

\footnotetext{
${ }^{7}$ A carta de Donisthorpe à Nature é reconhecida como uma reação à publicação pela Scientific American de uma notícia enaltecendo o recém anunciado fonógrafo.
} 
representação absolutamente completa e para isso, acredito, não esperaremos muito (tradução nossa).

\subsubsection{Zoopraxiscope - Projetando o Movimento}

Muybridge, de modo a facilitar a exposição de seus trabalhos para diversas pessoas, desenvolveu e produziu um projetor de imagens em movimento batizado de zoopraxiscope, no qual as fotografias eram copiadas e pintadas sobre um disco de vidro que ao ser girado, exibia-as em série. Além do movimento perfeito, pois utilizava cópias de fotografias, o aparelho apresentava imagens coloridas, uma vez que depois de transferidas para o vidro eram pintadas manualmente.

Iniciando em 1879, o inventor inglês excursionou pela Europa com seu recém produzido aparato, pelos três anos seguintes, e permaneceu um tempo pesquisando em Paris, onde se acredita, tenha influenciado um bom número de outros inventores.

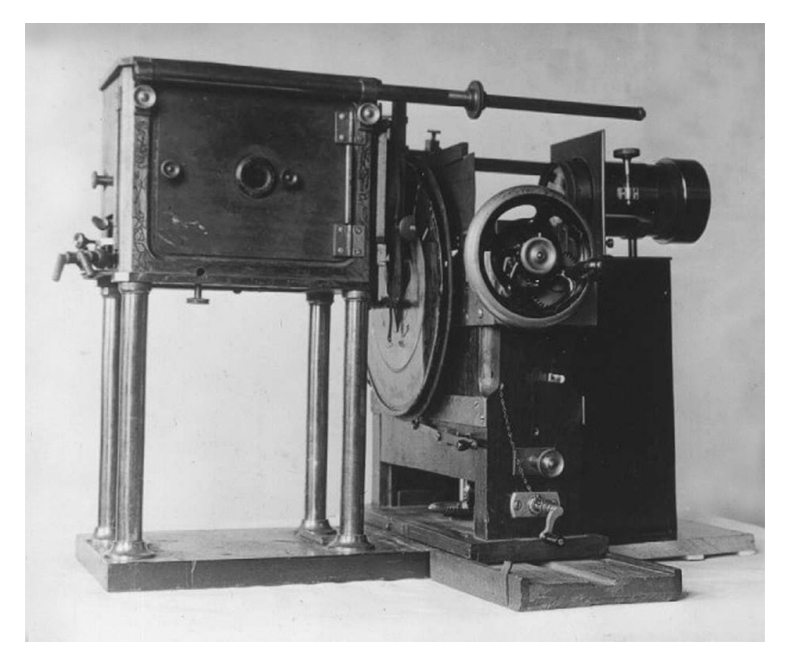

Figura 2.8 - Zoopraxiscope, de 1879

Ao retornar aos Estados Unidos da América, recebeu um financiamento da Universidade da Pensilvânia para prosseguir com seu projeto de fotografia stopmotion, um estudo fotográfico detalhado de perscrutação do movimento, composto por mais de 100.000 chapas, que consumiu mais que dois anos para ser concluído e 
que, ainda hoje, é uma excelente referência para animadores e desenhistas querendo estudar dinâmica do movimento.

\subsubsection{Tiras de Filme e uma Câmera Cinematográfica Portátil}

Em 1882, Antoine Lumière, que se somava ao rol de inventores da época, criou a "Lumière e Filhos" para produzir e comercializar chapas fotográficas usando a gelatina de secagem rápida. Nos anos seguintes, investiria tempo em pesquisa e contrataria pesquisadores proeminentes, desenvolveria tiras de filme, filmes em rolo e, muito mais significativo, em 13 anos desenvolveria o primeiro projetor / câmera a obter sucesso comercial utilizando filme à base de celulóide.

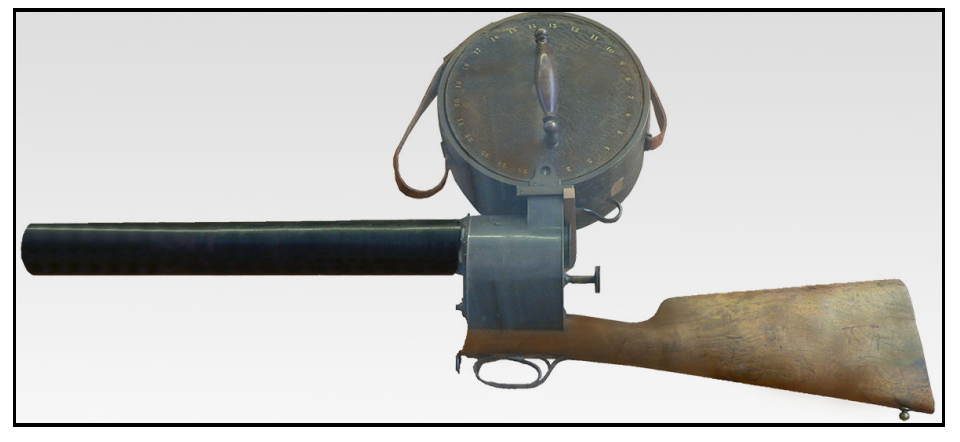

Figura 2.9 - Fusil Photographique

No mesmo ano, Marey, que em parceria com Muybridge pesquisava o registro fotográfico do movimento, desenvolveu o Fusil Photographique. Uma câmera fotográfica, valendo-se de gelatino brometo, no formato de um fuzil militar, que conseguia fotografar em $1 / 720$ de segundo. Capturava doze fotos em seqüência e foi essencial para o estudo do vôo dos pássaros e insetos conduzido por Marey. Tratava-se da primeira câmera de cinema portátil fabricada. Vários outros o sucederam, muitas vezes ignorando seu fuzil, tais quais Friese Greene, Leprince, Anschutz e tantos outros. 


\subsubsection{O Quinetoscópio - o Primeiro Produto da Indústria}

George Sadoul, em seu livro "O Cinema", descreveu o kinetoscope de Willian Dickson como o primeiro produto da indústria cinematográfica: "O Quinetoscópio, que Edson pôs a venda em 1894, pode ser considerado o primeiro produto da indústria cinematográfica, porque esta caixa, em que o espectador vê diretamente as imagens das fitas, ampliadas por intermédio de uma lupa, contém um filme quase igual ao filme moderno."

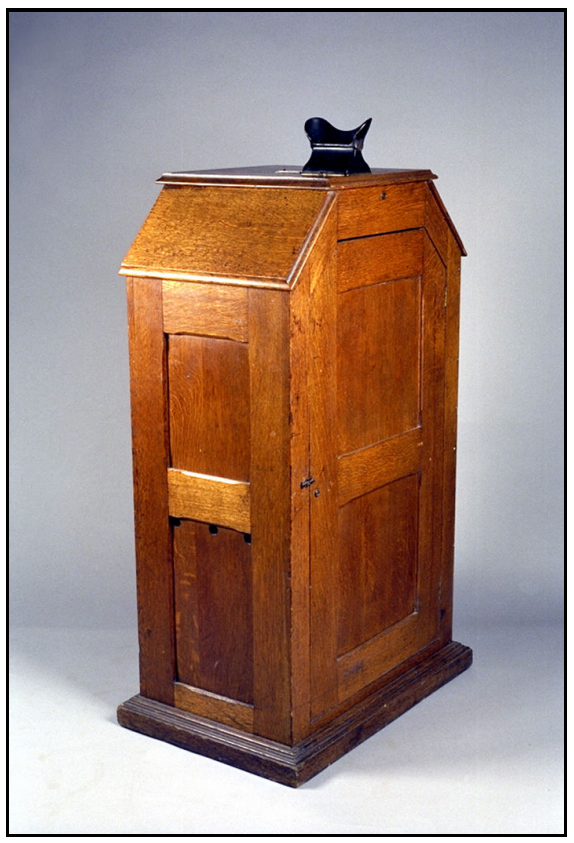

Figura 2.10 - Kinetoscope de 1894 


\subsection{5 - Irrompe o Cinema}

O ano de 1895 foi marcado pelo aparecimento, em diversas partes do mundo, de sistemas de projeção cinematográfica. Cronologicamente: Lê Roy, Latham, Armat e Jenkins, Anschutz, Skladanowski e, próximo ao fim do ano, Louis Lumière. As realizações dos predecessores de Lumière alcançaram pouco sucesso, seja pela menor perfeição técnica ou pior localização geográfica; e hoje, a exibição do Cinematógrafo Lumière no subsolo do Grand Café, no Boulevard des Capucines, em Paris, é considerada como a estréia da arte e da indústria do Cinema.

A inovação do cinema espalhava-se pelo mundo e perto da virada do século milhares de películas já haviam sido produzidas. Reportagens, panoramas distantes, atualidades, curiosidades, cenas cômicas, a variedade de produtos era considerável. Foi neste caldo que George Méliès, diretor do teatro de prestidigitação Robert Houdin, percebeu que o cinema se beneficiaria ao empregar os métodos e aparatos do teatro. Combina, então, um estúdio fotográfico com um palco de teatro.

"Com Marey, o filme foi meio de pesquisa científica. Edson transformou-o em curiosidade científica. Lumière fez dele um processo de informação e quase de ensino. Estava reservado a George Méliès impô-lo como espetáculo e arte narrativa". [Sadoul]

No início do século $X X$, isento de alguns pormenores secundários, 0 aparato técnico do cinema encontrava-se desenvolvido o suficiente para torná-lo um suporte confiável e funcional. Inúmeras salas de projeção permanentes existiam e os shows itinerantes levavam o espetáculo a todos os cantos.

Com o corpus mechanicum ${ }^{8}$ criado, conteúdo e forma passaram a receber maior atenção. Muitos dos olhares dos então acostumados com a técnica voltaramse para questões mais subjetivas, inerentes à narrativa e distintas do suporte. $\mathrm{O}$ corpus misticum ${ }^{9}$ começava a tornar-se o objeto de estudo.

\footnotetext{
${ }^{8} \mathrm{O}$ entendimento de corpus mechanicum é o do suporte da obra. Assim, um mesmo filme no formato de DVD e em película tem o mesmo corpus misticum, mas cada uma das mídias possui um corpus mechanicum diferente. ${ }^{9}$ Corpus misticum, também mysticum, é a obra em si, independentemente do suporte. É imaterial e pela lei que rege o direito autoral no Brasil, dificilmente encontra proteção enquanto não manifestada.
} 


\section{Realização Cinematográfica}

\subsection{O Computador Corteja o Cinema}

Os avanços tecnológicos otimizaram técnicas, refinaram processos, criaram e extinguiram profissões, equipamentos, modelos de negócio, impulsionaram significativamente o cinema e, conseqüentemente, transformaram profundamente hábitos, comportamentos e as relações sociais. Em boa parte das obras, pelo resultado na tela, este processo evolutivo não passa despercebido. Mesmo quem não é estudioso do assunto, ou tem sua relação com o filme limitada apenas ao eventual papel de espectador, é capaz de perceber as conseqüências de técnicas cinematográficas que, por lançarem mão de tecnologia mais avançada, resultam em imagens de maior impacto.

Pode-se dizer que a indústria cinematográfica, de forma geral, não sofre repentinas transformações. Suas mudanças ocorrem de maneira lenta e gradual, sem alterar significativamente sua estrutura, que há várias décadas enquadra-se no mesmo modelo. O advento dos equipamentos digitais, com seu custo decrescente, tolerância a erro, grande disponibilidade e facilidade de operação, introduziu uma nova variável nesta indústria e preocupou alguns de seus integrantes com a possibilidade de perda de influência.

Na década de 70 o computador começou a aproximar-se das telas do cinema. Alguns autores creditam a Westworld, 1973 (Westworld - Onde Ninguém Tem Alma), que usou imagens geradas por computador (CGI - Computer-Generated Imagery) para representar a subjetiva do pistoleiro robô, a primeira introdução em um longa-metragem de planos CGI. Os filmes Star Wars Epsidode IV A New Hope, 1977 ( Guerra nas Estrelas) e Tron, 1982 (Tron - Uma Odisséia Eletrônica) são outras obras bastante citadas por inovarem, utilizando CGI nesta época pioneira.

Paulatinamente, as imagens sintéticas digitais aumentavam sua participação na indústria cinematográfica, abrindo uma pequena fresta nas portas 
dos estúdios. Entretanto, eram consideradas recurso caro, desnecessário e destinado meramente a completar imagens captadas da maneira rotineira, com película e câmeras cinematográficas. Seu indisfarçável aspecto artificial contrastava com boa parte dos gêneros e tratamentos visuais do cinema, restringindo sua ampla aceitação e estigmatizando-as como ferramentas de efeitos especiais.

\subsubsection{O Último Guerreiro das Estrelas: o Primeiro a Estrelar}

$\mathrm{Na}$ indústria cinematográfica, até então, o computador fizera algumas pontas em filmes de ficção científica, mas ainda não tivera a oportunidade de uma contribuição verdadeiramente significativa. Sua grande chance, que pode ser considerada como um marco na utilização exclusiva de CGI para a geração de imagens, veio com o The Last Starfighter, 1984 (O Último Guerreiro das Estrelas), um filme de ficção científica sem grande evidência na bilheteria e muitas vezes sem receber o merecido destaque na história do cinema.

A Digital Productions, responsável pela geração das imagens dos efeitos visuais, optou por gerar todas as cenas envolvendo naves, vôos e combates espaciais, no computador. O The Last Starfighter representou uma espécie de prelúdio da era das imagens sintéticas foto-realistas ${ }^{10}$, ao apresentar pela primeira vez cenas geradas exclusivamente por computador.

\footnotetext{
${ }^{10}$ As imagens geradas por computador para o The Last Starfighter, quando submetidas aos padrões hodiernos, nitidamente não atingem o grau de refinamento necessário para receberem a classificação de foto-realismo. Contudo, representavam o ápice da tecnologia em meados da década de 80.
} 


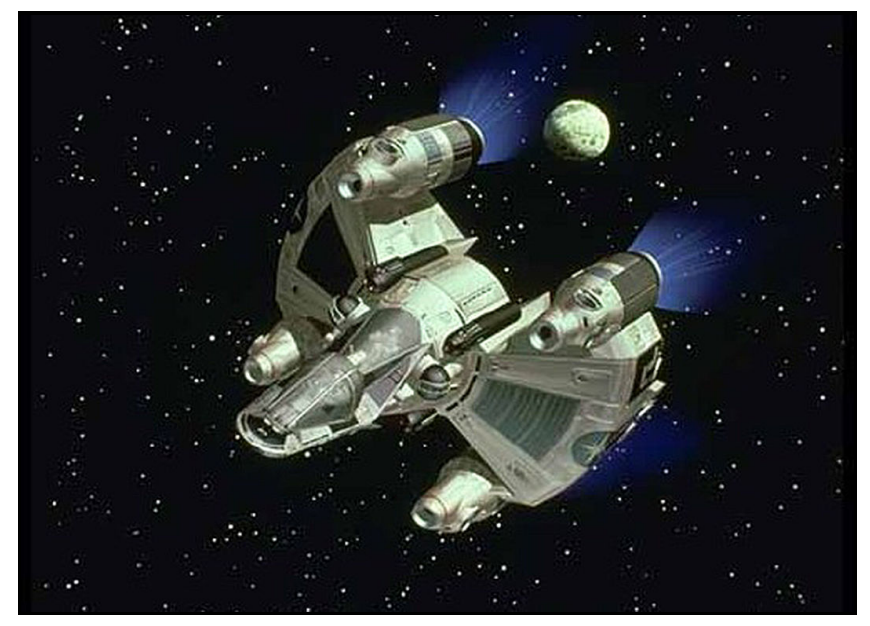

Figura 3.1 - Last Starfighter, 1984 - CGI substituindo maquetes

Numa época em que o paradigma de produção de imagens custosas, arriscadas ou para ficção científica, completamente consagrado e garantido, era o da utilização de maquetes e miniaturas, a Digital Productions mergulhou de cabeça no projeto e investiu pesado apostando no potencial da nova tecnologia. Se as imagens tivessem fracassado, junto fracassaria a empresa.

Reunir o poder de processamento necessário para gerar as imagens de 3000 x 5000 pixels de cada um dos fotogramas, daqueles descomunais 27 minutos de CGI, foi tarefa de extrema dificuldade e nada barata. A Digital Productions lançou mão de um supercomputador CRAY XMP, que, com seus 400 megaflops de pico, custava cerca de 15 milhões de dólares e trabalhava várias horas nos cálculos de cada quadro das cenas geradas digitalmente. 


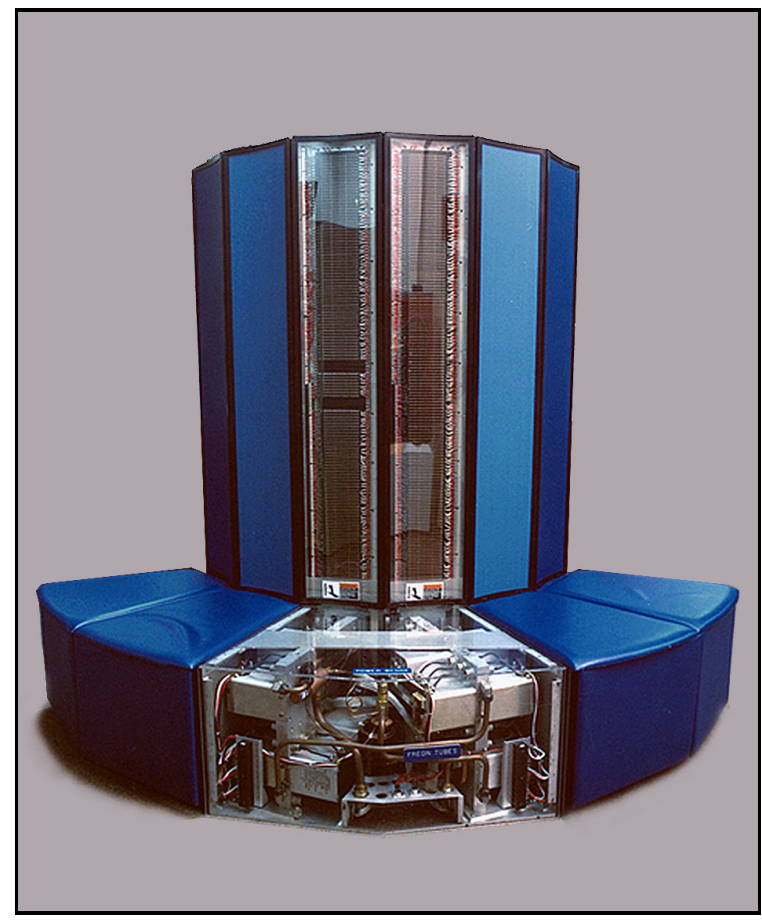

Figura 3.2 - Supercomputador CRAY XMP

A conquista em termos visuais e tecnológicos foi tamanha que John Whitney, Jr. e Gary Demos, fundadores e responsáveis técnicos da Digital Productions, receberam o 57 Academy of Motion Picture Arts and Sciences' Scientific and Engineering Award, o Oscar da Ciência e Engenharia, pela simulação foto-realista de fotografia cinematográfica por meio de imagens geradas por computador, pelo seu trabalho no "Último Guerreiro das Estrelas" utilizando o CRAY XMP, 1984 (Academy of Motion Picture Arts and Sciences website, Disponível em: http://awardsdatabase.oscars.org/ampas_awards/BasicSearch?actio n=searchLink\&displayType=1\&BSFromYear=57, Acessado em: Jun. 2005).

Hoje, a Digital Productions já foi comprada, vendida e fundida. O CRAY XMP virou peça de museu e um mero videogame tal qual o X-Box, apresenta mais do que o quíntuplo do poder de processamento ${ }^{11}$ deste supercomputador de outrora.

\footnotetext{
${ }^{11}$ Cray X-MP possuía processamento dual - 105 MHz CPU capaz de 400 MFLOPS. (tech specs e Cray History, Disponível em http://www.cray.com e http://www.nsa.gov/museum/museu00018.cfm\#cray, Acessado em: Abr. 2007). Já o XBOX, processamento simples, 32-bits $733 \mathrm{MHz}$ Mod Celeron. 4 single-precision floating point numbers por ciclo de clock, com um GPU de $233 \mathrm{MHz}$ "NV2A", 4 pixel pipelines com 2 texture units cada - 932
} 
Contudo isso, aquele empreendedor primeiro passo de John Whitney, Jr. e Gary Demos deu resultados tão positivos e, continuado, alterou o modelo de produção em tal grau, que a geração de imagens sintéticas por computador é atualmente, em muitos casos, a primeira alternativa do cinema industrial.

\subsection{Fases da Realização Cinematográfica}

A indústria cinematográfica, em especial a americana, é dominada por alguns poucos grandes estúdios, baseados principalmente na Califórnia, ao redor de Hollywwood, que produzem não apenas obras cinematográficas, mas também filmes realizados $^{12}$ especificamente para a televisão, musicais e comerciais. Diversas empresas ligadas a esta indústria por lá se estabeleceram para oferecer aos estúdios produtos e serviços que otimizassem o fluxo de trabalho e a, por conseguinte, a própria realização cinematográfica. De aluguel de equipamentos a recursos e soluções de pós-produção, tais quais: aberturas, legendas, montagem, closed captioning, créditos finais, transfer de filme e vídeo, animação, gráficos gerados por computador e efeitos especiais.

Não é de difícil aceitação a noção de que as técnicas cinematográficas e o fluxo de trabalho para realização de um filme nos dias de hoje diferem em muito do cinema incipiente de Melliès e seus contemporâneos. Entretanto, pode-se analisar as realizações cinematográficas hodiernas e retrógradas, dividindo-as nas mesmas cinco fases: desenvolvimento, pré-produção, produção, pós-produção e distribuição.

Desenvolvimento: nesta fase, o roteiro é escrito e reescrito até tornar-se viável para produção. O orçamento é calculado e, onde há cinema industrial

megapixels/second. Capaz de 2.93 GFLOPS. . (Feel the Power, Disponível em http://www.xbox.com/enUS/hardware/x/xbox360prosystem/feelthepower.htm, Acessado em: Abr. 2007)

${ }^{12}$ Neste trabalho, a expressão "realizar o filme" é empregada com o significado de "fazer o filme"; o processo de transformar uma idéia (imaterial), uma noção, uma estória, um conceito, em um registro físico (material) - algo abstrato em algo concreto. No jargão audiovisual, sem prejuízo de significado, também com bastante freqüência, utiliza-se "produzir" em referência a este processo de realização cinematográfica. De maneira a resguardar o entendimento, o termo "produção" será aplicado referindo-se à uma fase específica da realização, na qual ocorre a captação. Complementarmente, "realização" será utilizado em referência à elaboração do filme. 
estabelecido, propostas são apresentadas aos investidores para a captação dos recursos necessários.

Pré-produção: nesta fase, o filme é planejado e desenhado. A equipe é contratada. As cenas são colocadas nos story-boards, visualizações são preparadas e são elaborados desenhos conceituais. Verbas de produção são alocadas dentro dos limites do custo do filme.

Produção: nesta fase, outra parte da equipe é contratada, os cenários são montados, iluminados e, efetivamente, as imagens captadas.

Pós-produção: nesta fase, o filme é montado ${ }^{13}$, ocorre a marcação de luz, a sonorização, geração do interpositivo, preview e master.

Distribuição: nesta fase, o filme é duplicado, press-kits preparados, campanhas de divulgação iniciadas. Pré-estréia e festa de lançamento.

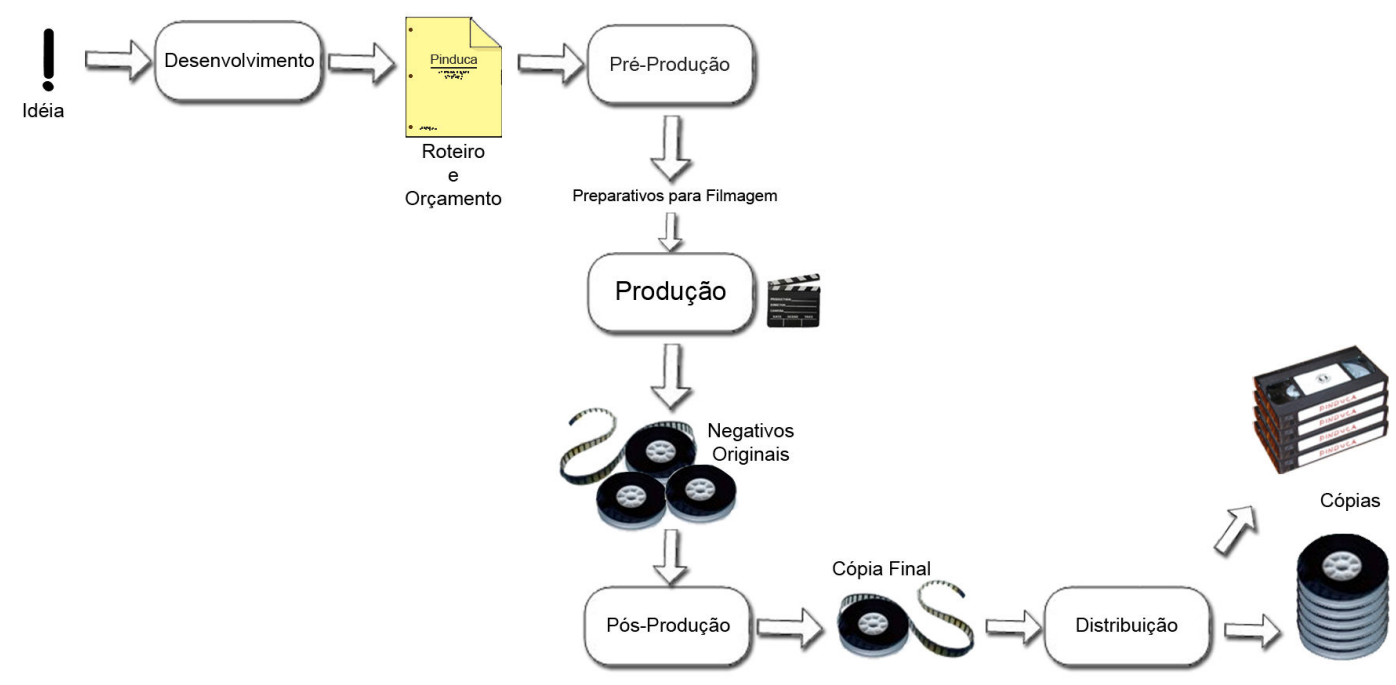

Figura 3.3 - Realização no Cinema Industrial

\footnotetext{
${ }^{13}$ Há alguns autores que agrupam a montagem à fase de produção, outros optam por uma outra divisão. (HAYASHI, S., 2003) escreve "[...] A realização de um produto cinematográfico passa fundamentalmente por três fases: captação, edição e pós-produção". Face às transformações já implantadas e às outras subentendidas com o desenvolvimento do cinema digital, consideramos que a divisão nas cinco fases supracitadas ofereçam um quadro mais flexível e duradouro para a análise.
} 


\subsubsection{Desenvolvimento}

A primeira manifestação de um filme ocorre na fase de desenvolvimento. É nela que a idéia, a visão do autor, efetivamente transcende do mysticum para o mechanicum ${ }^{14}$, materializa-se, passa a existir na forma de roteiro.

Consideramos válidas as argumentações de que esta foi a fase pela qual o computador começou a aproximar-se da indústria cinematográfica, uma vez que o meio corrente para a apresentação, manipulação e arquivamento de roteiros era o papel. Até o início da década de 90, uma máquina de escrever e papel eram os recursos necessários para se escrever um roteiro. O computador teve sua difusão impulsionada justamente por substituí-los com grande benefício.

Dependendo do viés da análise, se pactuada a idéia de que esta fase foi a porta de entrada do computador na indústria cinematográfica, o fato de que a introdução da máquina de escrever elétrica dotada de memória em fita magnética, batizada de processador de texto, e que tornou as manipulações e correções no texto mais fáceis e ágeis, pode ser empregado como subsídio para a teoria. Entretanto, na nossa avaliação, esta assertiva não merece grande destaque, pois o processador de texto penetrou nas empresas, indiscriminadamente, substituindo a antiga máquina de escrever, do cartório ao laboratório de pesquisas.

Justificamos com isso, o não detalhamento da participação do computador nos processos exclusivos da fase de desenvolvimento, visto que consideramos a contribuição para as fases posteriores muito mais significativas que a edição de texto e elaboração de planilhas de orçamento para o projeto de captação de recursos. Rigorosamente, a etapa de pós-produção foi a que primeiro recebeu o computador num encargo cinematográfico importante.

\footnotetext{
${ }^{14}$ Corpus misticum, também mysticum, é a obra em si, independentemente do suporte. É imaterial, a idéia desprovida de suporte. $\mathrm{O}$ entendimento de corpus mechanicum é o do suporte da obra. Uma livro, uma foto, um trecho de filme cinematográfico, um desenho, uma gravura, a partitura de uma música, o CD, o DVD e etc...
} 


\subsection{Processo Clássico de Realização}

Durante décadas, o processo de realização de um filme e seu fluxo de trabalho não foram alterados significativamente. Uma das principais características do processo clássico é a de que a película ${ }^{15}$ cinematográfica é utilizada em todas as etapas da realização, independentemente da bitola de captação ser a mesma do produto final ou ainda da utilização de suporte intermediário. Ou seja, a captação é feita por meio de película cinematográfica e, após a conclusão dos trabalhos, a projeção também ocorre através de filme, sendo $35 \mathrm{~mm}$ a bitola mais comum para exibição no cinema comercial.

\subsubsection{Pré-Produção}

A pré-produção envolve a montagem de uma primeira equipe, encarregada de refinar o projeto, detalhando e planejando cada uma de suas fases posteriores, de maneira que o roteiro seja transformado no filme, respeitando os limites do orçamento.

São elaborados storyboards para auxiliar a visualização das cenas, desenhos de produção para transmitir o tom do filme, escolhidos atores e demais profissionais à medida que são necessários, determinadas as locações, os estúdios, determinadas empresas parceiras, selecionados técnicos e atores, desenvolvidos objetos de cena, preparados contratos, documentos e, se necessários, realizados testes de captação.

A regra geral é a de que todas as ações que, obrigatoriamente, devem anteceder as atividades do período de captação das imagens e som, ou as diretamente ligadas a ele, pertencem à fase de pré-produção.

\footnotetext{
${ }^{15}$ Película e filme, apesar de serem sinônimos, adquirem significados ligeiramente distintos quando meticulosamente empregados. Película designa mais comumente o filme cinematográfico virgem, ou não processado, aquele ainda sem imagens fixadas. E filme, um estágio posterior, refere-se à película exposta, revelada e fixada, apresentando imagens em fotogramas. Contudo, em situações que não exijam tal rigor, geralmente não há prejuízo de entendimento do uso alternado destes dois termos.
} 


\subsubsection{Produção}

Na fase de produção, informalmente conhecida também por "filmagens", depois de montados e iluminados os cenários, posicionados os técnicos e atores, ocorre a captação das imagens e do som. Durante esta fase, a equipe encontra-se com o maior número de pessoas trabalhando ou, simultaneamente envolvidas no projeto. Nas filmagens é obtida a matéria prima, imagens e sons, com a qual se construirá o filme.

A captação das imagens no processo clássico é realizada por meio de uma câmera cinematográfica, que quando acionada, permite que a luz refletida dos cenários e atores atravesse a lente e atinja a película virgem alojada em seu interior. Esta película, um suporte transparente coberto por uma emulsão de sais de prata, normalmente pancromática, ao ser atingida pela luz, ativa quimicamente os cristais fotossensíveis, registrando neles uma imagem latente, quando passa a ser chamada de exposta.

Neste estágio, ainda não é possível ver a imagem registrada, pois o próprio ato de observá-la faria com que mais luz atingisse a película já exposta, afetando uma segunda vez os cristais e alterando o que foi anteriormente captado. Ela fica cuidadosamente protegida da luz até que seja enviada ao laboratório.

No laboratório cinematográfico, passa por um tratamento químico com o objetivo de separar os cristais que não receberam luz dos que foram sensibilizados e fixar a imagem latente, tornando-a permanente. Este tratamento, que recebe o nome de revelação, compreende uma série de banhos químicos diferentes, que converte os cristais em prata metálica e os remove da película. Por serem minúsculas estas partículas, uma imagem de grande latitude da cena originalmente impregnada permanece. Uma das características do processo é a da imagem permanente ter o aspecto negativo da originalmente exposta. $\mathrm{O}$ que era claro é registrado como escuro e vice versa. Nas películas coloridas, fixam-se no negativo as cores 
complementares às primárias do sistema aditivo ${ }^{16}$ : o vermelho é registrado como ciano, o verde como magenta e o azul como amarelo.

A película já estabilizada, revelada, ou seja, com a imagem permanente, pode então ser manipulada sem a preocupação de danificá-la por exposição acidental à luz. Neste estágio é chamada simplesmente de negativo ou negativo original. Este pode ser utilizado para gerar uma imagem fotográfica em papel, valendo-se de um ampliador, que é uma espécie de projetor. Neste processo, o negativo funcionará como um filtro, bloqueando parte da luz que pelo ampliador passaria rumo ao papel ${ }^{17}$. Há também a alternativa de se projetar a luz filtrada pelo negativo sobre uma película virgem e, desta forma, obter uma imagem negativa daquele negativo: um filme com imagem positiva que ao ser projetado na tela exibirá as cores aparentes na captação.

$\mathrm{Na}$ indústria cinematográfica de porte, costuma-se revelar e assistir às imagens captadas diariamente ${ }^{18}$, de maneira a identificar eventuais problemas de captação e, se necessário, capturá-las novamente antes que se tenha encerrado o período de produção. Uma vez terminadas as filmagens, o resultado da captação é normalmente uma pilha de rolos de filme revelado e fitas magnéticas, conseqüência dos diversos esforços de produção. Esta pilha será posteriormente manipulada pelo montador, que pela justaposição das cenas fixadas no negativo, determinará o ritmo do filme e conferirá sentido à obra.

\footnotetext{
${ }^{16} \mathrm{O}$ sistema aditivo é o que classifica as cores baseadas em suas freqüências no espectro eletromagnético, coresluz. As cores visíveis para o olho humano são as do vermelho ao violeta. As cores primárias do sistema aditivo são a vermelha, a verde e a azul. Na língua inglesa abreviadas como RGB (Red, Green e Blue) e popularizadas pelo sistema de cor componente usado nos equipamentos eletrônicos, televisores, monitores de vídeo, reprodutores de DVD. Pela maior difusão do sistema subtrativo, quando do ensino infantil, a simples menção às cores primárias já remete equivocadamente ao azul, vermelho e amarelo. Mesmo no sistema subtrativo, corespigmento, as primárias são ciano, magenta e amarelo (CMY). Normalmente, materiais destinados à impressão valem-se do formato CMYK para maior fidelidade de cores. CMYK são as cores CMY + K preto. As cores complementares no sistema aditivo são $\mathrm{R}<->\mathrm{C}, \mathrm{G}<->\mathrm{M}, \mathrm{B}<->\mathrm{Y}$.

${ }^{17} \mathrm{O}$ papel fotográfico, para tornar a imagem permanente, também passa por um processo químico que envolve vários banhos químicos, de maneira análoga ao da película.

${ }^{18}$ Recebem o nome de daillies nos Estados Unidos e rushes na Europa.
} 


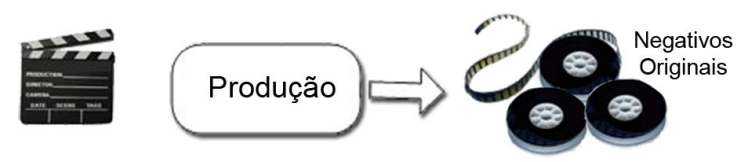

Figura 3.4 - Produção Clássica - o Negativo em Toda a Linha

\subsubsection{Pós-Produção}

Na montagem clássica, logo após a revelação do negativo, produzem-se os copiões, que são cópias positivas das cenas captadas, passíveis de projeção e manuseáveis. Os negativos originais ficam cuidadosamente arquivados para que não sofram danos, pois, valiosíssimos, são a materialização dos esforços e investimentos feitos em todas as fases anteriores. O montador trabalhará cortando e colando estes copiões, seguindo as orientações do roteiro, em conjunto com o diretor, de maneira a organizar detalhes, intensificar emoções e minorar eventuais defeitos.

Nesta etapa da montagem, o centro das atividades do filme deixa de ser o estúdio e passa a ser a sala de edição, por vezes adjacente ao estúdio ou instalada no próprio laboratório de copiagem. O equipamento essencial desta sala é a montadora, que encontrou sua mais popular manifestação na Moviola ${ }^{19}$, um equipamento que permitia ao editor assistir ao copião e ouvir os sons sem a necessidade de recorrer a um projetor.

\footnotetext{
${ }^{19}$ A Moviola, inventada em 1924 por Iwan Serrurier e aperfeiçoada por seu filho Mark Serrurier, em 1946, tornou-se em pouco tempo sinônimo de montadora, pois nenhum outro equipamento contemporâneo aproximava-se de sua eficiência e confiabilidade. Em 1979, Mark Serrurier recebeu o Technical Academy Award of Merit - "Pelo desenvolvimento progressivo da Moviola de 1924 inventada por seu pai, Ivan Serrurier, até a presente série 20 de sofisticados equipamentos de edição cinematográfica." (All the Oscars:1979, disponível em: theoscarsite.com/1979.htm, acessado em:23/10/2006)
} 


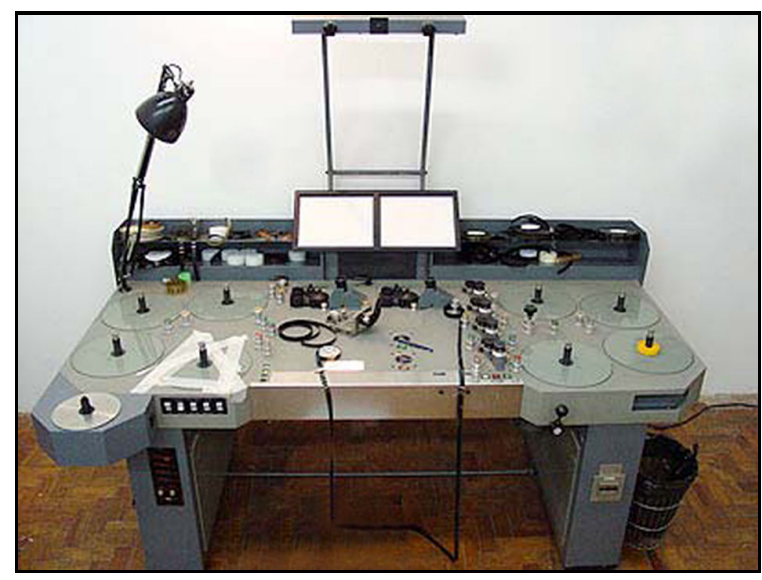

Figura 3.5 - Moviola Flatbed

A película cinematográfica, sabemos, pode ser explicada como um suporte transparente coberto por uma emulsão de sais de prata sensível à luz, na qual, por um processo químico, é possível gravar imagens permanentemente. Esta traz em suas duas ${ }^{20}$ laterais perfurações padronizadas utilizadas para tracioná-la. Junto destas perfurações, há informações que servem para identificar e localizar os fotogramas do negativo, tal qual um índice: são os números de borda, key numbers, key codes ou edge numbers ${ }^{21}$.

A dinâmica de trabalho do montador consiste, normalmente, em assistir aos copiões e deles separar as tomadas capturadas, identificando-as, organizandoas e catalogando-as para posterior utilização. Dependendo do tamanho do projeto, do estilo do montador e do andamento da edição, as paredes da sala de montagem ficam repletas de segmentos de negativos, pendurados e etiquetados. Em seguida, os seguimentos do copião são refinados e colados em uma nova ordem de modo a imprimir ao filme o ritmo desejado.

Esta separação dos segmentos é efetivamente um corte no filme. $\mathrm{Na}$ ausência de uma coladeira, cortadeira ${ }^{22}$ ou guilhotina, este corte pode ser realizado

\footnotetext{
${ }^{20}$ Alguns tipos de película trazem as perfurações em apenas um dos lados.

${ }^{21}$ No negativo $35 \mathrm{~mm}$ os key number são impressos a cada 16 fotogramas, o equivalente a $30,48 \mathrm{~cm}$ (um pé). Opcionalmente, pode ser adicionada ao negativo a pietagem, uma informação visual a cada pé de filme.

${ }^{22}$ A cortadeira ou guilhotina traz pinos que balizam o posicionamento da película sob a lâmina e a mantém no gabarito durante o corte. Adicionalmente, na coladeira, o rolo de fita adesiva fica convenientemente posicionado para que se possa colar os segmentos sem grandes manipulações.
} 
com uma tesoura. A junção de dois planos é feita pela justaposição dos segmentos do copião, fixados com uma fita adesiva apropriada. Este, que é o mais simples dos cortes, é conhecido como corte seco, pois a exibição passa diretamente do último fotograma de uma cena para o primeiro da posterior.

Há diversos outros tipos de cortes que servem para pontuar visualmente o filme, impondo-Ihe significados que vão muito além do simplesmente mostrado nas imagens. Fusões, clareamentos, escurecimentos e cortinas ${ }^{23}$, durante anos, evoluíram dentro da montagem e constituem muito mais que uma alternativa de corte no repertório do montador conhecedor da linguagem cinematográfica. Contudo, não é possível concluir ou mesmo visualizar este grupo de cortes na montadora. Faz-se necessário a utilização de trucagens ${ }^{24}$ para concluí-los. O que acontece, ainda na pós-produção, normalmente depois de refinada a primeira cópia de trabalho.

Dias depois de iniciada a montagem, é disponibilizada uma primeira cópia de trabalho. Esta, apesar de trazer pontas de filme, ou passagens padrão, em substituição aos efeitos de trucagem desejados, apresenta cenas com a extensão prevista no roteiro e, aproximadamente, obtida nos ensaios. Depois de projetada e acompanhada, esta cópia será passada e repassada na Moviola, onde o montador ajustará o ritmo, suprimirá imperfeições e refinará os cortes.

No cinema, a voz dos atores, o ruído dos objetos, o som ambiente e a música não são captados e gravados no mesmo suporte que a imagem. O som de um filme é confeccionado posteriormente, num processo laborioso, que trabalha cada um dos elementos sonoros separadamente e depois os une na banda sonora. Pode-se segmentar o som cinematográfico em três categorias: a voz dos atores, que em boa parte das realizações é gravada, na fase de produção, concomitantemente à

\footnotetext{
${ }^{23}$ Com a popularização dos equipamentos de vídeo e incorporação de muitos dos efeitos visuais especiais ao próprio equipamento, em especial os cortes, a nomenclatura em inglês, dissolve, fade-in, fade-out, wipe tornouse bastante conhecida e muitas vezes é empregada em substituição ao termo em português.

${ }^{24}$ Os efeitos visuais especiais realizados em geral pelo laboratório fotográfico são conhecidos também como trucagens.
} 
captação das imagens ${ }^{25}$, todavia em suporte próprio - num gravador Nagra $^{26}$ ou DAT, por exemplo; a trilha com os ruídos dos objetos de cena e do ambiente é composta por uma variedade de pequenos trechos pós-sincronizados à imagem - o estilhaçar de uma janela, os passos apressados na escada, o chamar de um telefone, o sibilar do vento, o estampido de um tiro, o circundante e confuso ruído do trânsito -muitas vezes são criados inteiramente pelos profissionais ${ }^{27}$ responsáveis pelo som; e, por fim, a trilha musical que estabelece e reforça o tom emocional das cenas, criando o contraponto audiovisual ${ }^{28}$. O conjunto de todos os sons mixados e já sincronizados com a imagem, constitui a banda ou trilha sonora. Esta é enviada em fita magnética ao laboratório para que seja transcrita para película ótica.

Finalizada a montagem, o filme encontra-se terminado e não mais poderá ser alterado. O corte final do filme comportado no copião, que neste estágio é a única materialização da parte visual do projeto, é enviado ao laboratório para que seja feito o corte do negativo original.

Nesta importante e delicada etapa, um técnico especializado corta o negativo tomando como referência os números de borda, de maneira que os segmentos do original sejam idênticos aos do copião. Estes segmentos são unidos com uma cola especial e passam por um analisador de cor, onde o diretor de fotografia e o colorista, determinam o color timing ${ }^{29}$, ou marcação de luz, do filme.

\footnotetext{
${ }^{25}$ Alternativamente a voz pode ser pré-sincronizada, recurso bastante utilizado em musicais e vídeo clipes, onde uma gravação prévia do ator é colocada em autofalantes no estúdio, ou locação, e, no momento da filmagem, o ator move os lábios em sincronismo, como se estivesse cantando. Outra opção é a pós-sincronização, na qual, após a captação das imagens, na fase de pós-produção, os atores gravarão suas vozes assistindo às cenas montadas, tentando manter o sincronismo - automated dialog replacement ADR nos E.U.A. e possynchronization na Europa. Este recurso, que era utilizado basicamente quando uma cena externa não continha extensos diálogos, passou a fazer parte da rotina de alguns diretores que as utilizavam mesmo em cenas rodadas em estúdios. Rossellini é um dos exemplos usuais desta prática.

${ }^{26} \mathrm{O}$ gravador Nagra, com sua fita de $1 / 4$ de polegada, é um dos ícones do som no cinema e durante cerca de quatro décadas foi a melhor escolha, do ponto de vista técnico, para a gravação de som direto. Com o passar dos tempos e maior difusão das tecnologia digitais, o Nagra perdeu espaço para o gravador DAT - Digital Audio Tape - que valendo-se de uma fita de $4 \mathrm{~mm}$ encapsulada, garantia altíssima qualidade amostrando a $48 \mathrm{khz}-16 \mathrm{~b}$. Lançado na década de 80 pela Sony, ocupou o lugar de seu antecessor com fitas magnéticas não por muito tempo. No ano passado, 2005, a Sony anunciou que a produção do DAT seria descontinuada. Estabeleceu-se a gravação em disco rígido.

${ }^{27}$ Os termos são diversos para designar os profissionais responsáveis pelo som do filme: diretor de som, operador de som e assistente de som; sonoplasta, som direto e operador de boom; engenheiro de som, técnico de som e microfonista; design de som, operador de boom (e outras variações). Para nosso objetivo, optamos por nos referir ao conjunto, independentemente da nomenclatura adotada.

${ }^{28}$ Eisenstein referia-se à montagem combinada das imagens, do som, das palavras e da música como contraponto audiovisual.

${ }^{29}$ Em inglês, o termo mais abrangente para a marcação de luz é color-grading, pois engloba as correções fotoquímicas, eletrônicas e digitais. Contudo, para o processo foto-químico o mais adequado é o termo color-timing,
} 
O processo de marcação de luz consiste em ajustar o nível de cada um dos três feixes de luz primários, vermelho, verde e azul, que atravessam o negativo rumo à película virgem onde será impressa uma nova cópia e assim, balancear suas cores. A marcação de luz é utilizada não apenas para corrigir alterações cromáticas indesejadas conseqüentes de iluminação desigual, captação em ambientes diferentes ou exposição equivocada, mas principalmente para conferir o tom desejado às imagens. O visual do filme é o resultado do esforço de captação, refinado pelo color-timing.

O filme resultante da junção do corte final com a banda sonora em película ótica é conhecido como cópia zero ${ }^{30}$ e, examinando esta cópia, o diretor de fotografia determina se são necessários outros ajustes na marcação de luz. São feitos tantos ajustes quantos forem necessários e comportados no orçamento, até que se chegue à cópia final.

Finda esta última etapa passível de alterações, obtém-se a cópia final e o próximo passo, levando-se em consideração que há verba prevista no orçamento, é a geração de uma cópia positiva em filme especial, conhecida como master, ou interpositivo $^{31}$. Dela é feita uma cópia negativa, também em filme especial, conhecida por contratipo ou internegativo e que se presta à geração das cópias para exibição.

A utilização do contratipo permite que os negativos originais sejam resguardados contra eventuais danos no manuseio e desgaste na copiagem, assegurando que a obra mantenha-se acessível por longos anos, arquivada. Finalizado, internegativo disponível, e pronto para ser duplicado, o filme passa à fase de distribuição.

que também é desenvolvido pelo laboratório fotográfico. Nos Estados Unidos, é rara a presença do diretor de fotografia durante o color-timing. O técnico colorista, baseando-se nas conversas que teve com ele e na sua própria experiência, aplica as correções necessárias.

${ }^{30}$ Dependendo do autor consultado, encontram-se os termos negativo definitivo (answer print em inglês), cópia zero, primeira cópia.

${ }^{31}$ Master positivo e interpositive também são encontrados. 


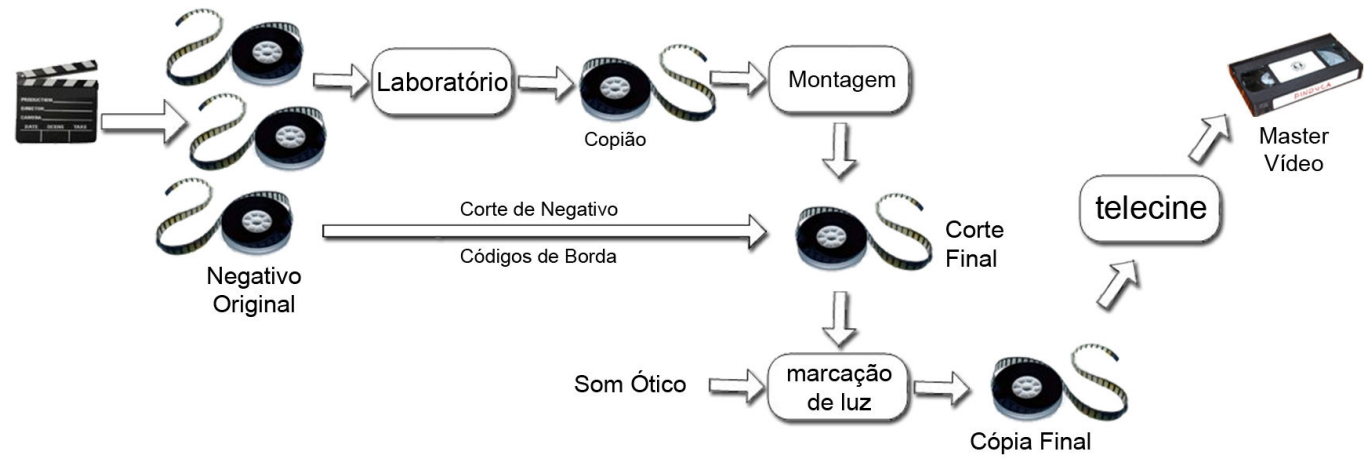

\subsection{Distribuição}

Uma definição resumida do papel do distribuidor seria a de fazer o exibidor assinar o contrato de reserva de exibição do filme em seus cinemas, usando como ferramenta de convencimento sessões exclusivas de exibição e técnicas de marketing. Mostrar-lhe que lucraria significativamente com a programação daquele filme, gerenciar toda a logística de transporte, fiscalizar a exibição, administrar o repasse das receitas e, ao fim do contrato, retornar o filme ao produtor.

Independentemente desta definição bastante simplista deixar de lado as dinâmicas de mercado e transmitir uma falsa noção de que o distribuidor ocupa uma posição mais fraca do que realmente o faz, ela presta-se para identificarmos boa parte das atividades do processo de distribuição, praticadas em formato quase que idêntico ao da "era dourada de Hollywood ${ }^{32 " . ~}$

\footnotetext{
${ }^{32}$ Era dourada de Hollywood refere-se ao período da história do cinema americano do fim do cinema mudo até o fim da década de 50, quando os filmes eram produzidos em série, seguindo uma formula, tal qual quaisquer outros produtos industriais.
} 
As leis anti-truste, o declínio do studio system ${ }^{33}$, o suposto desaparecimento da "verticalização" e o cinema pós-clássico provocaram mudanças muito mais amplas na estética e na linguagem do que na estrutura comercial da indústria cinematográfica americana. Os distribuidores ligados aos grandes estúdios, valendo-se de política de bloco ${ }^{34}$ e de técnicas de manipulação de reserva, sempre obtiveram grande sucesso em manifestar sua influência na indústria cinematográfica. Este modelo clássico de distribuição, face aos altos custos de duplicação e relação íntima com os estúdios, continua conferindo aos distribuidores grande força, da qual, certamente, não abrirão mão voluntariamente.

Valendo-se do contratipo, o distribuidor duplica o filme em quantidade suficiente para atender o lançamento simultâneo previsto em sua estratégia ${ }^{35}$, que, dependendo do filme, chega a milhares de salas. O custo de cada cópia de um filme $35 \mathrm{~mm}$ fica em torno de 1000 a 1500 dólares $^{36}$ e como cada sala lançadora precisa da sua própria, a distribuição de um block-buster gasta em média cinco milhões de dólares apenas na duplicação. No Brasil, uma vez que os lançamentos ocorrem em um número menor de salas ${ }^{37}$ e o preço da duplicação é outro, chega a 700 mil dólares.

As cópias são então transportadas e consignadas aos exibidores que se encarregarão de disponibilizá-las ao espectador, arrecadar, retirar sua participação e repassar receitas ao distribuidor. Deste repasse, descontadas as despesas de copiagem e promoção acordadas, subtrai-se a comissão do distribuidor e o restante

\footnotetext{
${ }^{33}$ Valendo-se do studio system, a industria cinematográfica alcançava resultados muito bons, pois os filmes eram produzidos pelos grandes estúdios, em suas próprias instalações, com técnicos e artistas contratados permanentemente, preparados, distribuídos e exibidos pelos próprios estúdios, cuidavam da logística de distribuição de cópias e também possuíam as salas de cinema para exibição. Este sistema verticalizado teve sua força reduzida, no final da década de 40, pela lei antitruste e pelo advento da televisão.

${ }^{34}$ Política de bloco é o equivalente da prática de venda casada no mercado de varejo. O filme block-buster, amplamente cobiçado, quase certeza de bilheteria, só é disponibilizado ao exibidor, se este concordar em programar a exibição de outros cinco ou seis filmes não tão desejados, mas também oferecidos por aquele distribuidor.

${ }^{35} \mathrm{O}$ lançamento de um block buster nos E.U.A. é realizado em cerca de três a quatro mil salas. No Brasil, bem menos. O filme Tropa de Elite foi lançado em 140 salas (Sindicado das Empresas Distribuidoras Cinematográficas, Out 2007, Disponível em: http://www.sedcmrj.com.br )

${ }^{36}$ Esta faixa acomoda os lançamentos comerciais médios e o preço de duplicação. Apesar do preço de tabela da duplicação nos laboratórios ficar em torno de cinco mil reais, os distribuidores, pelo uso do internegativo, volume e dispensa da marcação de luz, recebem preços de 1200 dólares em média (Entrevista Ronaldo Câmara, gerente comercial da Labo Cine, Dezembro 2007)

${ }^{37}$ Geralmente no Brasil, block-busters são lançados de 300 a 600 salas.
} 
é entregue ao produtor ${ }^{38}$. Ao término do período de exibição, o distribuidor recolhe as cópias junto ao exibidor e as entrega ao produtor.

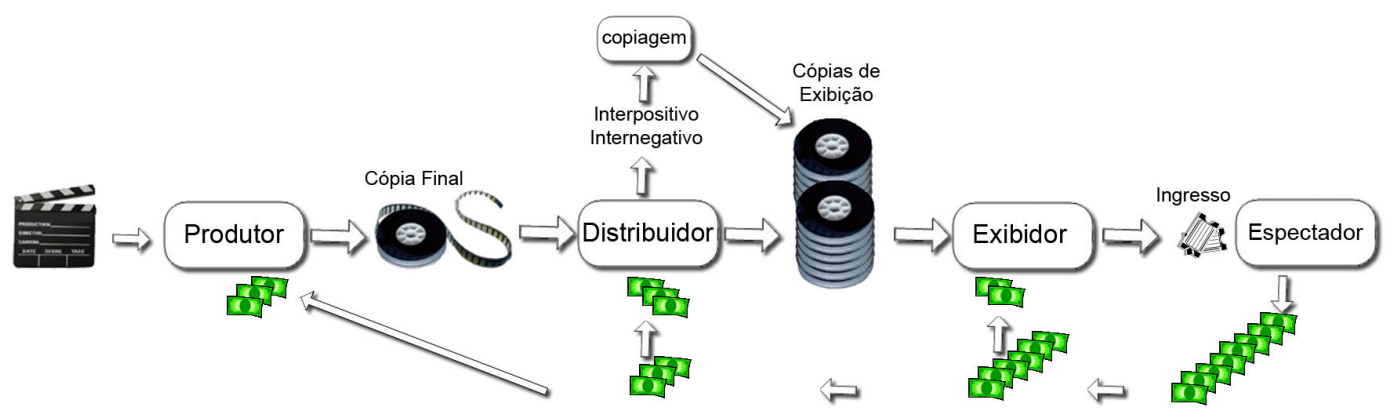

Figura 3.6 - Realização e Remuneração no Cinema

\subsection{O Advento do Telecine}

Com a popularização da televisão, percebeu-se que a transmissão de material captado em película ampliaria significativamente a gama de programas oferecidos aos telespectadores e proporcionaria às emissoras uma alternativa aos predominantes programas transmitidos ao vivo. Contudo, havia a necessidade de uma adequação técnica. A televisão exibia suas imagens a 25 ou 30 quadros por segundo $^{39}$ o que causaria problema ao, simplesmente, se transmitir filmes destinados à projeção a 24 quadros por segundo. A falta de sincronismo entre os quadros da película e a varredura da televisão seria percebida como uma oscilação, uma piscar da imagem.

As captações em película destinadas à televisão eram realizadas a $30 \mathrm{fps,}$ o que contornava a questão da falta de sincronismo. Ao se transmitir uma projeção destes filmes, cada fotograma ficava alocado em dois campos e não se constatavam

\footnotetext{
${ }^{38}$ Em se tratando de um acordo comercial, há uma variação significativa. Contudo, o fluxo dos recursos e das cópias não se altera.

39 Rigorosamente, a televisão convencional exibe 50 ou 60 campos (fields) entrelaçados, por segundo. Ao atualizar a imagem 50 ou 60 vezes por segundo, obtém-se um maior resolução dinâmica e conseqüentemente os movimentos parecem mais naturais.
} 
as oscilações na imagem. Os estúdios de transmissão, comumente agregavam projetores de slide, câmeras e projetores de cinema numa solução conhecida por film-chain.

Os filmes produzidos para cinema, entretanto, se simplesmente exibidos a 30 fps para descartar a falta de sincronismo, não apresentariam o movimento natural e sim uma imagem acelerada. A solução encontrada foi projetar o filme em sua velocidade original e captar eletronicamente estas imagens, realizando um processo de 2:3 pulldown ${ }^{40}$ onde cada quatro fotogramas geravam cinco quadros de transmissão e que permitia transformar as imagens do filme em sinal de televisão, sem perceptível prejuízo visual.

Com o aparecimento do gravador de vídeo em meados da década de 50 e o refinamento da técnica da imagem eletrônica nas duas seguintes, o diálogo entre o cinema e o vídeo tornou-se cada vez mais intenso. Uma mudança significativa ocorreu na fase de pós-produção cinematográfica ${ }^{41}$ : o telecine tornou-se parte da realização cinematográfica, como ferramenta de montagem.

\subsection{Processo Convencional de Realização}

A perfeita incorporação do processo de telecinagem na linha da pósprodução, sua facilidade de trabalho e a redução constante no custo dos equipamentos fizeram com que fosse tão amplamente adotado, que há quem faça referência ao fluxo de trabalho envolvendo o uso do telecine na montagem como "processo clássico" em substituição ao mais adequado "processo convencional".

De maneira simplificada, o telecine pode ser definido como um equipamento utilizado para converter imagens de filme em vídeo. Segundo (PINCUS, E. e ASCHER, S., 1984) seu nome origina-se da junção da palavra "televisão" com a "cinema" - TELE + CINE. Apesar de ainda existirem alguns

\footnotetext{
${ }^{40} \mathrm{O}$ processo pulldown, quando para transmissões no sistema PAL, utiliza o 2:2, no qual apenas o $12^{\circ}$ fotograma é duplicado.

${ }^{41}$ A fase de pós-produção tem se mostrado a mais aberta às inovações e alterações na dinâmica de trabalho.
} 
poucos equipamentos de telecine analógicos, baseados em fotomultiplicadores e fotodiodos, os mais modernos utilizam dispositivos de carga acoplados - CCD charge-coupled-device - e são quase que totalmente predominantes.

Na linha convencional, logo após a revelação dos negativos, as imagens são transferidas do filme fotográfico para fitas de vídeo através do telecine ${ }^{42}$. 0 montador determina os cortes e fusões, valendo-se de equipamentos de edição de vídeo, lineares ou não, de maneira equivalente ao seu trabalho na Moviola, obtendo como resultado uma única fita, que comporta o filme em seu corte final.

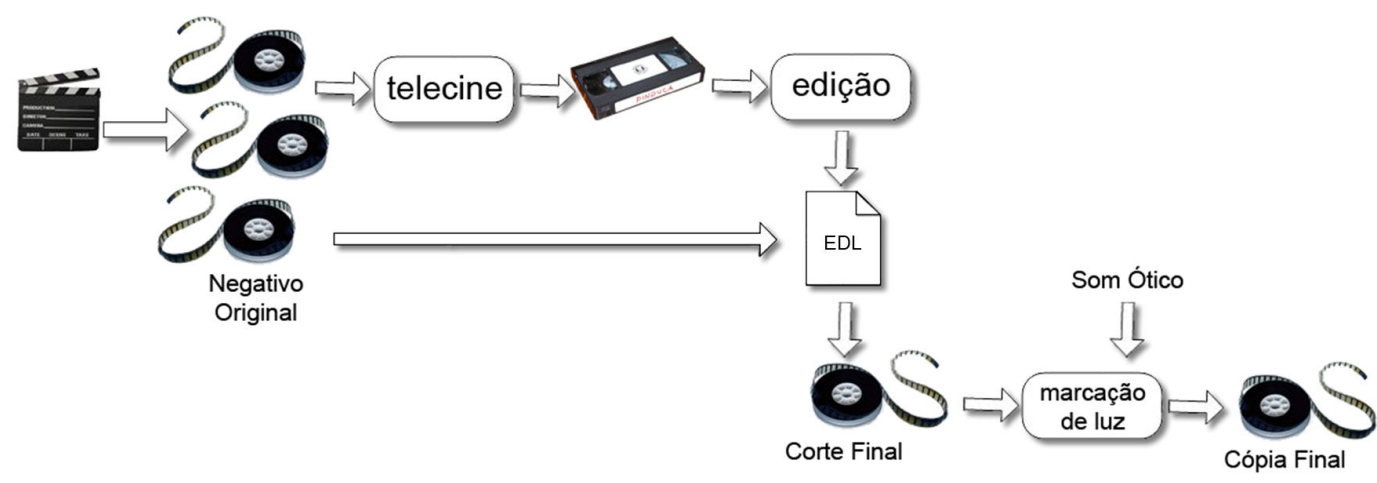

Figura 3.7 - Fluxo da Pós-Produção Convencional - Saída para Cinema

A fita de vídeo com o corte final é enviada para o laboratório, que se valendo do timecode ${ }^{43}$ gerado pelo telecine e dos códigos de borda, efetua o corte e montagem do negativo original. Este negativo, de maneira análoga ao método clássico, é utilizado para marcação de luz e na produção da cópia zero.

Com a difusão do uso do vídeo doméstico, o popular vídeo cassete, e a conseqüente consolidação de um mercado de consumo audiovisual residencial, o

\footnotetext{
${ }^{42}$ No cinema industrial de porte, o filme resultante das daillies ou rushes é utilizado para produzir as fitas para o telecine.

${ }^{43} \mathrm{O}$ timecode gravado na fita de vídeo é um código numérico, normalmente padrão SMPTE/EBU com oito dígitos, que registra a hora, minuto, segundo e o frame de uma determinada imagem na fita - 01:32:45:12
} 
telecine recebeu uma outra tarefa, a de transcrever a cópia final do filme para vídeo, gerando um master para vídeo duplicação.

Antes do aparecimento dos reprodutores de DVD dotados de progressive scan, os filmes lançados eram originados a partir deste mesmo master a $30 \mathrm{fps}$. Atualmente, estes mais avançados reprodutores são capazes de interpretar um fluxo de dados a $24 \mathrm{fps}$, dotado de sinais de sincronismo ${ }^{44}$, e realizar o pulldown no momento do envio das imagens para o projetor de vídeo ou TV. O telecine para este tipo de DVD é feito em geral a 24fps. Adicionalmente, as versões reeditadas fornecidas para o mercado televisivo, companhias aéreas e similares, também são geradas com base no produto do telecine.

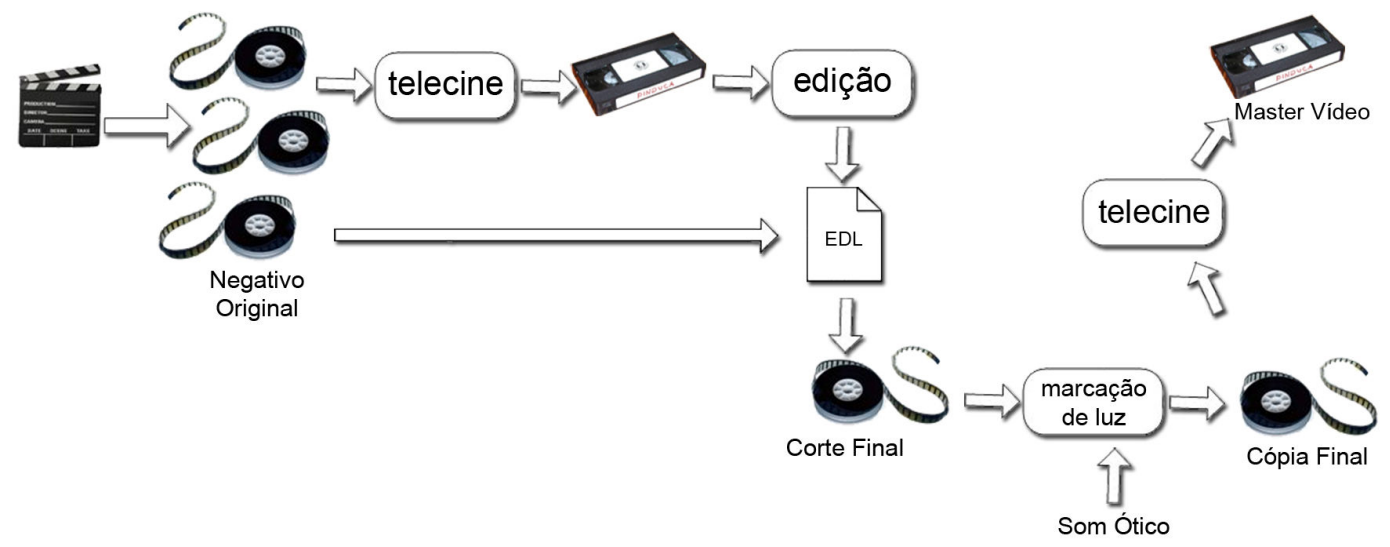

Figura 3.8 - Pós-Produção Convencional - Saída para Cinema e Vídeo

\footnotetext{
${ }^{44}$ Estes sinais, comumente chamados de flags, indicam ao reprodudor de DVD quando fazer o pulldown, uma vez que o filme está gravado no DVD a 24fps.
} 


\subsection{Processo Híbrido de Realização}

O modelo de pós-produção híbrida tenta aproveitar vantagens do processo clássico, do convencional e do puramente digital. Valendo-se de um intermediário digital, procura agregar a qualidade da imagem captada em película, o dinamismo e versatilidade da edição não-linear ${ }^{45}$ plena, a agilidade e flexibilidade de trabalho com material digital, a integração e possibilidade de trabalho paralelo colaborativo, o custo decrescente dos equipamentos digitais e a notória maior compatibilidade com o ainda incipiente cinema digital nos modelos da Digital Cinema Iniciative - DCl. Complementarmente, pode ser adotado por produções de variados formatos, mercados e orçamentos.

O conceito de intermediário digital torna-se cada vez mais presente. Com o avanço dos sistemas de computação e armazenamento, os enormes arquivos decorrentes da ingestão ${ }^{46}$ de imagens de alta resolução e qualidade, tais quais a película, tornaram-se viáveis e manipuláveis. Há mais tempo implementada em outras áreas, como o mercado editorial com a diagramação eletrônica e o da produção videográfica com a edição não linear, a utilização do intermediário digital no cinema comercial ganhou maior impulso na década de 90, quando o estúdio Disney, em parceria com a Pixar, lançou o primeiro longa metragem em película cinematográfica a ser originado de arquivos digitais "Bernardo e Bianca II" (The Rescuers Down Under).

O fato do custo da pós-produção utilizando DI ter sido reduzido significativamente permitiu que a manipulação digital das imagens se propagasse dos filmes contendo efeitos especiais para o cinema em geral. E Aí, Meu Irmão, Cadê Você? (O Brother Where Art Thou?), lançado em 2000, foi o primeiro filme a utilizar o intermediário digital sem a justificativa e motivação dos efeitos especiais.

Aos que outrora duvidavam da convergência, o DI sinaliza que sua efetiva adoção é inevitável. A televisão, o vídeo, o cinema, o computador e a internet estão

\footnotetext{
${ }^{45}$ Edição não linear plena é aquela na qual tanto o acesso ao material quanto a montagem ocorrem de maneira não linear.

${ }^{46}$ A ação que anteriormente se conhecia pelo termo genérico de digitalizar, com o desenvolver do Intermediário Digital DI - Digital Intermediate, passou a ser referida pelos termos mais específicos: aquisição ou ingestão (Aquisition - Ingestion).
} 
tão próximos que suas fronteiras começam a se confundir, tornando difícil determinar quando acaba um e começa outro. Nesta conjuntura, o termo audiovisual torna-se cada vez mais adequado, pois o espectador tem diversas opções de suporte para assistir a uma determinada obra - o cinema do bairro, na sua própria casa em seu reprodutor de DVD, em seu computador pela internet.

\subsubsection{O Intermediário Digital}

(JAMES, J., 2006) descreve o Intermediário Digital (DI) como "um paradigma para completar uma produção por meios digitais, seja o último épico de Hollywood ou vídeo de casamento amador", uma definição tão condensada que parte essencial de suas características não é contemplada. Os de visão mais alinhada com a indústria cinematográfica de porte, costumam simplificá-lo como um substituto dos intermediários fotoquímicos, sejam os interpositivos ou internegativos, pois, de maneira geral, são tiras de filme utilizadas para organizar e fazer manipulações no material captado originalmente, produzindo uma cópia final. Uma vez que os intermediários digitais são regra apenas em Hollywood, está última definição não encontra muita ressonância.

Na nossa visão, o Intermediário Digital é o paradigma de trabalho onde um material audiovisual matriz, independentemente de seu suporte, é apropriado em formato digital, manipulado matematicamente e, posteriormente, acomodado no suporte destino.

Pelo processo do DI, o material audiovisual deixa os átomos e abriga-se nos bits, perde a materialidade do suporte e recebe os benefícios da flexibilidade de manipulação da informação, dos dados, dos números. Alterações, operações e transformações realizadas em átomos são muitíssimo mais complicadas que as realizadas em bits.

Por esta definição, as manipulações realizadas com os populares programas de edição de imagem enquadram-se no paradigma do DI e oferecem-nos um exemplo mais próximo. Pode-se, num destes programas, ingerir imagens 
oriundas de um livro, de uma foto em papel, de um slide fotográfico e de uma foto digital, retocar os olhos vermelhos, melhorar o enquadramento original, alterar a cor das imagens, preparar um cartão de natal personalizado e em seguida imprimi-lo em papel fotográfico, projetá-lo num data-show ${ }^{47}$ ou ainda enviá-lo diretamente por email. O programa de edição de imagens lida apenas com os bits e, menos dependente dos átomos, livra-se das limitações da matéria.

O paradigma do Intermediário Digital é o mais flexível encontrado no momento e, presentemente, nenhum outro fluxo de trabalho apresenta os mesmos benefícios. Face a iminente consolidação do processo de convergência, as características flexíveis do DI reforçam-no como um recurso essencial à migração e, possivelmente, o modelo adotado na nova rotina. Adicionalmente, apesar do cinema digital como preconizado pela $\mathrm{DCl}$ ainda não ser uma realidade, o Intermediário Digital permite a preparação dos recursos e pacotes de distribuição sem grandes problemas de transição.

Desta forma, consideramos que o modelo de realização cinematográfica baseado no Intermediário Digital é o que mais benefícios apresenta, mesmo se imaginada a realização inteiramente digital, e, desta forma, procuraremos tomá-lo como referência quando da discussão do modelo alternativo para o filme transfer.

\subsubsection{Telecine e DI}

O telecine, como colocamos, é uma máquina utilizada para converter o filme cinematográfico em vídeo e, à medida que os antigos equipamentos analógicos (fotomultiplicadores e fotodiodos), hoje ultrapassados, cedem seus lugares aos mais modernos dotados de CCD, evidenciam-se os resultados da evolução da eletrônica e do processamento digital também sobre este equipamento.

Os mais recentes equipamentos de telecine possuem dispositivos de captura baseados em avançados CCDs, que fornecem imagens em alta resolução,

\footnotetext{
${ }^{47}$ Os projetores conectados diretamente ao computador, normalmente utilizados em apresentações empresariais, são popularmente conhecidos por data-shows.
} 
estão cada vez mais presentes e, dada a possibilidade de conexão em rede geração de pacote de dados, desenvolvem tarefas antes exclusivas dos film scanners ${ }^{48}$ com qualidade de imagem próxima.

A constante evolução dos sensores aponta para um momento em que a velocidade e resolução de captura dos equipamentos não será mais um fator limitante na aquisição de imagens. Esta evolução também é bastante evidente no própria resolução estática de captura do telecine que inicialmente capturava imagens em vídeo SD equivalentes a 420 mil pixels, depois 1 milhão, 2 milhões, 3,2 milhões e, recentemente, 12,7 milhões - imagens padrão 4K. Considerando apenas a resolução estática de uma imagem, uma imagem $4 \mathrm{~K}$ possui aproximadamente 40 vezes mais pixels que a área visível da televisão comum no padrão NTSC ${ }^{49}$.

O resultado de uma operação de telecinagem pode ser incorporado ao paradigma do Intermediário Digital com inúmeros benefícios. Entre eles, a possibilidade de aquisição de diversos rolos de filme antes de efetivamente ser gerada a fita de saída, integração de rolos ingeridos em momentos distintos, correções de cor adicionais feitas por operações matemáticas em contrapartida às aplicadas no telecine analógico e a edição e produção de versões com corte alternativo, sem degradação por múltiplas gerações.

\footnotetext{
${ }^{48}$ Os film scanners são usados para fazer a aquisição de imagens. Quando comparados ao telecine têm uma qualidade de imagem maior, porém demoram muito mais tempo para realizar o scan das imagens.

${ }^{49}$ Esta proporção que serve apenas para ilustrar a evolução do telecine, toma como base uma imagem $4 \mathrm{~K}$ (4096x3112) e uma televisiva, visível, ntsc equivalente a (650x486).
} 

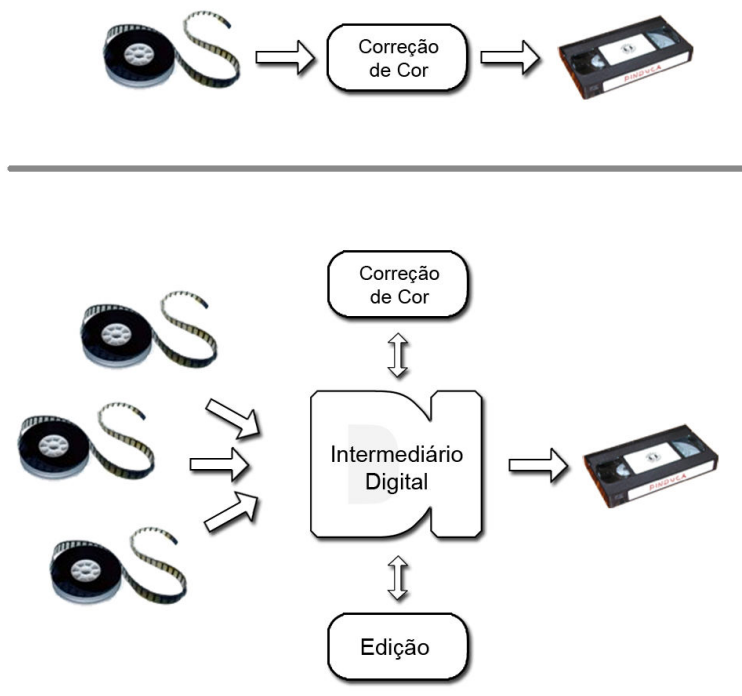

Figura 3.9 - Telecine vs Telecine Paradigma DI

\subsubsection{Processo de Pós-Produção com DI e Exibição em Filme}

No processo ideal de pós-produção utilizando o intermediário digital para exibição em filme ${ }^{50}$, todas as matrizes são ingeridas e este material, já desprovido suporte físico, é passado e repassado entre os diversos computadores da estrutura envolvidos no processo de manipulação dos dados, para depois ser convertido no formato de saída desejado, a película.

\footnotetext{
${ }^{50}$ Apesar de não ultrapassarem 3\% dos projetores instalados no mundo (abril de 2006), a projeção digital está tornando-se mais freqüente. Daí a opção por "exibição em filme" em substituição ao "exibição cinematográfica".
} 


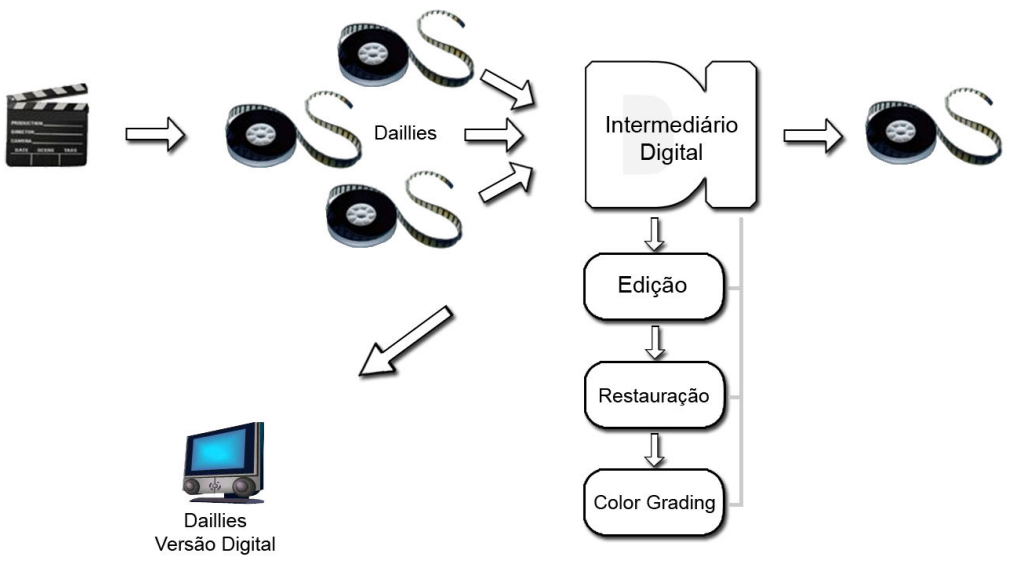

Figura 10 - DI - Fluxo Ideal para Exibição em Filme

Apesar do grande avanço da informática e meios de comunicação, uma vez que se tenta trabalhar no limite da tecnologia para produzir as imagens na melhor qualidade disponível, os arquivos de dados são, via de regra, grandes demais para a transmissão na velocidade necessária para a viabilidade do modelo ideal. A tecnologia de informação continua a evoluir manufaturando computadores cada vez mais potentes e uma vez que a qualidade das imagens atinja o limite discernível pela visão humana, os posteriores avanços da estrutura podem ser redirecionados para a transmissão e processamento dos dados.

Mesmo com as concessões necessárias para operar atualmente utilizando o intermediário digital, o recurso mostra-se bastante vantajoso, sendo que o mesmo equilíbrio de produção existente em outras áreas deve ser encontrado: qualidade, custo e tempo ${ }^{51}$. Emprestando um exemplo da física, onde o trabalho é proporcional ao tempo em que a força empregada atua, para processar mais informação em menos tempo são necessários computadores e estruturas mais avançadas, resultantes sempre dos investimentos.

Diversas realizações têm empregado modelos distintos deste ideal, mas que produzem resultados de igual qualidade, num fluxo alternativo menos dinâmico, gerado pela incorporação combinada de processos aprendidos no modelo convencional e no de produção em vídeo. Esta mesma premissa de mantenimento

\footnotetext{
${ }^{51}$ Mais popular é a expressão "tripé preço - qualidade - prazo".
} 
da qualidade e alongamento de prazo permite gerar imagens de alta qualidade a custos razoáveis. Se projetada esta lógica, e aumentado consideravelmente o tempo, acreditamos conseguir-se-ão imagens de alta qualidade, a custos absorvíveis pela produção independente e de baixo orçamento.

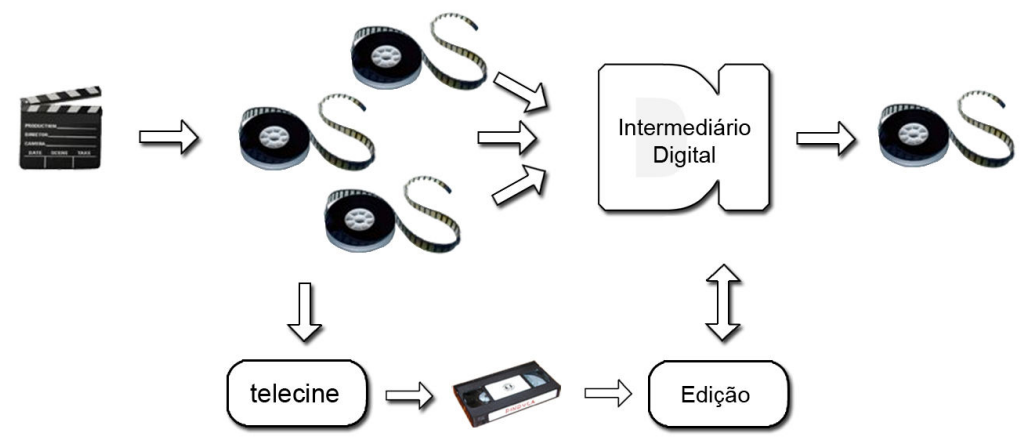

Figura 3.10 - DI - Fluxo Típico para Exibição em Filme

Este fluxo de trabalho na ilustração acima se justifica pela escassez de equipamentos de aquisição de imagens em qualidade elevada, conseqüência do alto custo dos mesmos e pelas melhores infra-estruturas e soluções de armazenagem necessárias para se trabalhar no modelo de intermediário digital ideal. Nesta solução típica, o corte final é montado com base nas fitas do telecine, tal qual o processo convencional, e pronto o corte final, com base na EDL ${ }^{52}$, o material necessário é ingerido para o DI, de onde segue para as outras etapas idealizadas - restauração, limpeza, color-grading, títulos, etc... até que, usualmente via film printer, seja transferido para película.

\footnotetext{
${ }^{52} \mathrm{EDL}$ um arquivo exportado pelo sistema ou preparado manualmente pelo editor que contém as informações referentes aos cortes praticados e ordem em que o material deve ser montado. Sistemas modernos são capazes de ler estes arquivos e preparar automaticamente o material, fazendo a operação conhecida por conform. A sigla é a abreviação de Edit Decision List.
} 


\title{
3.7.4 Bits em Substituição aos Átomos
}

O sistema linear de edição de vídeo saiu completamente de cena e em seu lugar surgiram os mais eficientes editores não-lineares, que debutaram em meados da década de 80 , de forma analógica, e se desenvolveram significativamente na década seguinte. $O$ sistema de edição não linear é aquele que permite o acesso de forma aleatória, ou seja, o material pode ser obtido fora de seqüência. Um outro entendimento que foi muito difundido do termo não-linear foi a não linearidade do material montado, pois com o sistema, podia-se montar os 15 primeiros minutos do filme, depois inserir um plano novo depois do minuto sete, encurtar os quatro primeiros minutos do resultado, sem que para isso fosse necessário refazer todo o trabalho que sucedia o ponto de alteração.

Tomando como base este uso estendido do termo, a própria montadora cinematográfica pode ser classificada como um sistema não-linear. (HAYASHI, S., 2003) cita o exemplo da Moviola como equipamento de edição não linear e em seguida, descreve algumas limitações do sistema:

\begin{abstract}
A limitação dos sistemas não lineares como a Moviola, que fazem uso do filme como suporte de trabalho, estão ligados á linearidade física do armazenamento e do acesso ao material. Assim, ainda que um rolo de filme positivo possa ser manipulado em qualquer ponto, na ordem em que se desejar, o acesso ao material desejado é obrigatoriamente linear e implica no percurso através de todo o material existente entre o ponto onde se encontra o rolo de filme positivo carregado no equipamento e o ponto que se deseja acessar.
\end{abstract}

Uma das maiores limitações de sistemas que se valem de montadoras e que afeta também o processo de pós-produção convencional, no qual uma fita é editada e usada como referência para o corte do negativo, é a materialidade do suporte. A imagem inscrita no filme existe em por seus átomos e com estes não se interage de maneira tão fácil tal qual com bits. 
A duplicação de uma imagem em película exige a duplicação de seus átomos, gerando um segundo seguimento de filme nos quais outros átomos replicam a imagem do primeiro. Esta duplicação, em se tratando de um processo fotoquímico, é sujeita às perdas e degradações inerentes ao processo. Os resultados de operações com átomos propagam e acumulam os erros de cada uma das partes participantes. Uma vez que este tipo de erro inerente, aumentado com cada participante da equação, não ocorre nas operações matemáticas, o processo de intermediário digital está isento dos limites de duplicações e replicações, pois os erros existem apenas nas etapas de transferência para o suporte e leitura do mesmo, quando entram em cena novamente os átomos.

O maior limite da matéria, dos átomos, é o de que eles não podem existir em dois lugares ao mesmo tempo. Assim, caso o mesmo segmento do negativo seja utilizado mais de uma única vez ao longo do filme, será necessário duplicá-lo antes de montá-lo. A película cinematográfica é degradada a cada operação de duplicação a que é submetida e, conseqüentemente, a mesma imagem aparecerá com níveis diferentes de qualidade.

A combinação de imagens no processo fotoquímico, bem como boa parte dos efeitos óticos, é obtida ao se somar fotograficamente as películas que darão origem ao efeito, utilizando um equipamento conhecido por optical printer, conhecido também por truca. A degradação na geração de efeitos óticos existe e, mesmo com o filmes especiais criados para tal, são obstáculos à criação do realizador.

Entendemos que, muito mais desvantajoso e restritivo que a linearidade do acesso e armazenamento das imagens em meio físico, é a existência dos limites da manipulação de imagem inerentes ao suporte em que se trabalha, seja ele a fita de vídeo ou a película cinematográfica. O intermediário digital não é afetado por eles, pois ao trabalhar apenas com a informação, os bits, torna-se menos suscetível às restrições da matéria, dos átomos. 


\subsection{Processo Digital de Realização}

O decrescente custo dos equipamentos e o avanço da tecnologia permitem que novas experiências sejam feitas, colaborando para redefinir não só as relações com o cinema, mas com a sociedade como um todo. A produção audiovisual digital vem desenvolvendo-se rapidamente e o suporte da internet permite que, não só o conteúdo seja exibido, mas principalmente o conhecimento propagado. Os grupos de discussão, os cursos de ensino à distância, os livros eletrônicos e vídeos tutoriais são apenas alguns dos exemplos de como a informação, o conhecimento, vem sendo difundidos pela rede.

Adicionalmente, sítios de compartilhamento ${ }^{53}$ de vídeo na internet tais quais o iFilm, Google Video, Yahoo video e Metacafe incentivam a produção, não só pela divulgação da obra, mas também oferecendo prêmios e recompensas financeiras. Outra iniciativa na mesma linha é o canal FizTv, lançado pelo grupo Abril no final de Julho de 2007, que exibe vídeos de independentes, amadores ou profissionais, enviados para a emissora via internet.

No ano de 2004, popularizou-se o termo Web 2.0, que, também carente de uma definição mais delimitada e universal, apresenta alguns significados que não se referem propriamente ao avanço dos equipamentos ou protocolos de rede, mas sim a uma nova mentalidade de incentivo à colaboração, compartilhamento de mídia e manifestações artísticas individuais. São abundantes os sites de relacionamento, networking, blogs e vblogs. Se antes faltava espaço para exibição, nesta nova realidade pode vir a faltar conteúdo.

A produção audiovisual em equipamento digital, por vezes chamada de maneira descomprometida de cinema digital, vem sendo intensificada e projetos que, jamais se imaginaria chegariam às telas, tornam-se sucessos de bilheteria. Um dos exemplos mais significativos é o de A Bruxa de Blair (The Blair Witch Project, 1999) que, produzido em $16 \mathrm{~mm}$ e vídeo Hi-8, conseguiu a décima bilheteria (the Blair

\footnotetext{
${ }^{53}$ Estes sites de compartilhamento de vídeo funcionam em vários modelos. De repositórios de vídeos acessíveis por uma simples interface, até uma estação de tv típica, com conteúdo escolhido e filtrado, mas onde quem faz a programação são os internautas. Em agosto de 2007, nosso levantamento mostrou que existiam pelo menos 43 destes sítios.
} 
Witch Project, Box Oficce Mojo) no ano em que lançaram blockbusters tais quais Star Wars - Ameaça Fantasma, the Matrix, A Múmia, Toy Story 2 e outros.

O processo envolvendo intermediário digital pode, com grande benefício, estruturar-se em um modelo inteiramente digital. Apesar de bastante desejado, prognosticado e de existirem algumas experiências inovadoras neste sentido, este não é, presentemente, um modelo de largo emprego. As realizações digitais mais abundantes são os longas-metragens de animações, Toy Story, Monsters, Os Incríveis e, mais recentemente, o esperado Beowulf que, também de maneira inovadora, utilizará a "representação melhorada digitalmente" (digitally enhanced live $\left.\operatorname{action}^{54}\right)$.
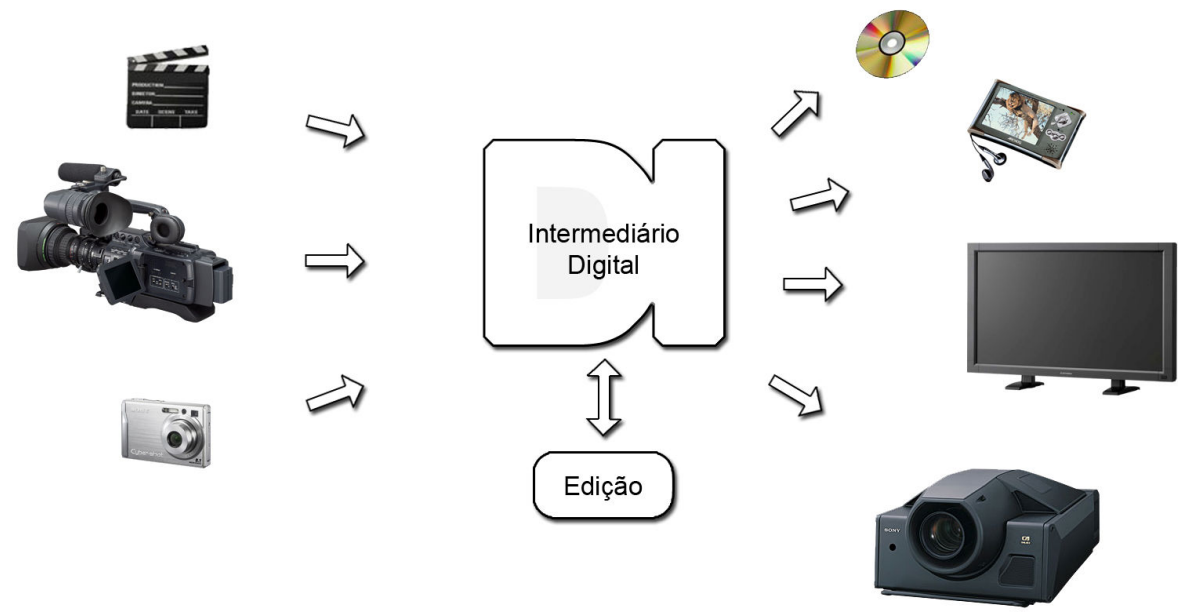

Figura 3.11 - DI - Realização Digital Integral

O intermediário digital é um paradigma para realização, capaz de se integrar perfeitamente aos mais diversos fluxos de trabalho, e que possibilita um alto grau de flexibilidade, controle e adaptabilidade, mantendo a qualidade do material matriz ao longo de toda a linha, permitindo a colaboração paralela, não linear e habilitando a geração de múltiplos formatos de saída.

\footnotetext{
${ }^{54}$ Digitally Enhanced Live Action - é uma nova técnica onde os movimentos dos atores são capturados e convertidos em dados digitais, inseridos num ambiente virtual e as ações são "exageradas" ou tornadas mais dramáticas.
} 


\section{Cinema Digital}

\subsection{Um termo com Múltiplos Significados}

À medida que a pesquisa avançava e consultava-se um maior número de fontes, constatou-se a diversidade de acepções comportadas pela incipiente expressão: cinema digital. Esta variação pode ser explicada pelas traduções apressadas, por vezes resultando na deturpação do conteúdo; pela flexibilização excessiva de alguns autores na utilização dos termos; pela falta de conceitos na elaboração de alguns trabalhos; pela falta de uma delimitação exata da expressão que seja reconhecida universalmente, mas sobretudo pela própria complexidade e multiplicidade de significados do vocábulo "cinema".

O termo digital, quando utilizado no contexto de informática ou tecnologia, comporta a significação daquele que trabalha com valores representados no sistema binário. Por apropriar-se do termo neste contexto, a expressão cinema digital fica sujeita às mesmas restrições desta definição.

Já a definição de cinema não é tão estreita, admitindo uma diversidade de significados. O dicionário Houaiss apresenta as seguintes definições para cinema:

- o conjunto das pessoas que trabalham na indústria cinematográfica;

- sala de projeção de filmes cinematográficos, sala de espetáculo com finalidade comercial e que é instalada e equipada para tal fim;

- o conjunto de princípios, processos e técnicas utilizados para captar e projetar numa tela imagens estáticas seqüenciais (fotogramas) obtidas com uma câmera especial, dando impressão ao espectador de estarem em movimento;

- meio de expressão e comunicação que utiliza esse processo;

- realização de obras cujo suporte físico é o filme cinematográfico e cujo objeto é a expressão artística da subjetividade humana, ou a criação de 
material documental, educacional ou de entretenimento, na forma de produtos de cunho semicomercial ou fundamentalmente comercial;

- o conjunto das atividades relacionadas com a produção de filmes cinematográficos; indústria cinematográfica;

- conjunto de filmes de um autor, de um país, de uma época;

Portanto, a acepção do vocábulo cinema pode igualmente ser um conjunto de pessoas, um espaço, um conjunto de princípios, processos e técnicas, um meio de comunicação, uma obra em película, um produto comercial, as atividades da indústria e o conjunto de filmes. Esta diversidade de significados é propagada para a expressão cinema digital.

\section{Georges Sadoul}

O cinema representa, portanto, simultaneamente, distração, meio de cultura, arte, indústria, comércio e técnica (SADOUL, G. O Cinema: sua arte, sua técnica, sua economia 2ed. Rio de Janeiro: Editora da Casa do Estudante do Brasil, 1956, Pg.13)

\subsection{Esforços da Indústria Cinematográfica}

Toda a excitação e promoção que recebeu o imaturo cinema digital geraram uma enorme expectativa na sociedade, incapaz de ser atendida na velocidade desejada. Neste contexto, o desenvolver não tão rápido quanto esperado da tecnologia, aliado aos complexos entraves de caráter comercial e a falta de definições universais, deixaram a expressão sujeita aos usos alternativos, completamente desregulados; e propagados de maneira rápida. Esta apropriação do rótulo "cinema digital" não é bem vista pela indústria que tenta recuperar o significado originalmente desejado, mas ocorre em tal grau que muitas vezes os significados alternativos são mais difundidos que o original. 
Michael Karagosian, em um artigo publicado na INS Asia Magazine ${ }^{55}$, tenta definir melhor o cinema digital:

As a starting point, I'll suggest a simple definition for cinema: the art of presenting motion pictures. Since this simple definition is not technologydependent, I can also define digital cinema as the art of presenting motion pictures. Note that I didn't define digital cinema as associated with digitally produced motion pictures. The source technology is not important. The "digital" in digital cinema is about the distribution format and how the image is displayed (KARAGOSIAN, M. INS Asia Magazine, Dez 2003)

My simple definition is elegant, but unfortunately, it has a problem. There's nothing in this definition that connects cinema to a particular image quality level. Why do we need this? This deserves a quick review.

Historically, cinema has been about the display of film-based content. While other distribution media have been introduced since the advent of film, such as broadcasting, consumer video tape, laser disc, DVD, and MPEG files over the Internet, none produce pictures superior to that of film. This natural division in quality has allowed motion picture exhibition to escape the electronic revolution of the past 50 years. More importantly, it is this division in quality that has made viable the staggered release windows that are unique to the distribution of motion pictures. By release windows, I refer to the timing of when movies are released on the various media available. DVD sales, for instance, generally do not take place until 4 to 6 months following the release of the movie in the theatre.

This has been the cause of much discussion in Hollywood, and indeed, most of the world, with the result that the accepted definition of digital cinema is the art of presenting first-run motion pictures.

Como ponto de partida, sugerirei uma simples definição para cinema: a arte de exibir filmes ${ }^{56}$. Uma vez que esta simples definição não depende da tecnologia, eu também poderia definir cinema digital como a arte de exibir filmes. Notem que não defini o cinema digital associado a filmes produzidos digitalmente. A tecnologia original não é importante. O 'digital' do cinema digital refere-se ao formato de distribuição e a como a imagem é exibida.

\footnotetext{
${ }^{55}$ INS Asia Magazine tornou-se a SIA, Systems Integrator Asia, uma publicação bimestral, dirigida aos profissionais e à indústria de $\mathrm{AV}$ e IT.

${ }^{56}$ Motion Pictures pode em alguns contextos ter o significado de "imagens em movimento". Contudo, para o deste artigo, julgou-se mais adequado a utilização de "filme" uma vez que em português significa tanto a obra quanto o suporte e o conteúdo.
} 
Minha definição simples é elegante, mas infelizmente, tem um problema. Não há nada nesta definição que associe o cinema a um nível particular de qualidade de imagem. Por que precisamos disto? Isto merece uma rápida recapitulação.

Historicamente, "cinema" refere-se à exibição de conteúdo em película cinematográfica. Enquanto outras mídias foram introduzidas desde 0 advento da película cinematográfica, tais quais transmissão televisiva, vídeo cassete voltado ao consumidor, laser disc, DVD e arquivos MPEG distribuídos pela Internet, nenhuma produz imagens superiores às da película cinematográfica. Esta divisão natural de qualidade permitiu à exibição de filmes escapar da revolução eletrônica dos últimos 50 anos. Mais importante, foi esta divisão de qualidade que tornou possível a prática de lançamento escalonado, que é exclusivo da distribuição cinematográfica. Por lançamento escalonado, refiro-me à programação de quando os filmes serão lançados nas diversas mídias disponíveis. A venda de DVDs, por exemplo, geralmente não ocorre antes de 4 ou 6 meses do lançamento do filme no cinema.

Isto tem sido motivo de muita discussão em Hollywood, e de fato, na maioria do mundo, resultando que a definição aceita de 'cinema digital' é a arte de exibir filmes em salas de primeira linha ${ }^{57}$ (nossa tradução).

\section{Posteriormente à publicação das especificações técnicas da Digital} Cinema Initiatives (DCl) para o cinema digital, a definição "aceita" de cinema digital, divulgada por Michael Karagosian, foi revisada para:

Digital Cinema: the highest-quality theatre display of cinematic content such as first-run feature motion pictures. Minimum performance specifications are intended to follow $\mathrm{DCl}$ specifications.

Cinema Digital: a exibição de conteúdo cinematográfico em salas de cinema, na mais alta qualidade, tais quais os longas-metragens em cinemas de primeira linha. Espera-se que as especificações de performance mínimas sigam as especificações do $\mathrm{DCl}$ (nossa tradução).

\footnotetext{
${ }^{57}$ First-run: no Brasil, utiliza-se "cinema lançador" ou de "primeira linha". Remete diretamente à prática da indústria cinematográfica de lançar o filme em algumas salas de cinema selecionadas e, passado algum tempo, utilizar aquelas mesmas cópias nas salas das cidades menores. Ou seja, o filme é lançado primeiro nos grandes centros e depois nas salas do interior. First-run seria o primeiro lançamento, as primeiras exibições, nestas salas de "primeira linha".
} 
Sintetizando, a definição propagada pela indústria cinematográfica, principalmente a americana, é a de que o cinema digital é o processo de distribuição e exibição baseado em equipamentos digitais, que atenda aos requisitos de qualidade estipulados pelos estúdios.

\subsection{Apetrecho Temporão}

O cinema digital ainda não se encontra maduro o bastante para unanimemente atrair o total interesse dos integrantes da área, ou mesmo mostrar-se como uma solução definitiva, de qualidade e utilidade incontestáveis. A forte dependência do suporte de informática propiciou-lhe, não só os benefícios desta área, mas também sua volatilidade e a efemeridade.

A obsolescência dos equipamentos de informática é precoce em demasia, quando comparada aos equipamentos de qualquer outra área. A conseqüente maior depreciação dos equipamentos certamente altera os pontos de equilíbrio de receita das empresas e indústrias, forçando seus executivos a refletirem profundamente antes de incentivar ou investir em alguma mudança muito radical.

A história é repleta de casos de alternativas tecnológicas e novas descobertas, que se esperava seriam adotadas universalmente, revolucionariam as atividades a elas associadas e que não sobreviveram mais que alguns instantes; ou mesmo formaram-se natimortas. Não há quem possa garantir com certeza que este modelo de cinema digital proposto pelos grandes da indústria não seria apenas mais uma delas e este motivo é forte o suficiente para exigir cautela dos que efetivamente perderiam muito dinheiro ao investir em uma outra tecnologia inócua.

A aproximação do universo da Tecnologia da Informação (TI) com o do Audiovisual - Áudio e Vídeo $\left(\mathrm{AV}^{58}\right)$ - colocou em choque duas estruturas de mercado

\footnotetext{
${ }^{58}$ Áudio e Vídeo é aqui utilizado no lugar de cinema por serem boa parte das regras válidas para ambas as indústrias e boa parte dos integrantes serem os mesmos. A expressão Áudio e Vídeo é mais abrangente, mas não a ponto de alterar o sentido da afirmação.
} 
poderosíssimas e bastante distintas. O mercado de $\mathrm{TI}$, extremamente consumista, tem um ritmo acelerado e muito se beneficia da rápida obsolescência dos equipamentos, programas, processos, técnicas e até dos profissionais. Sua dinâmica leva em conta a curtíssima vida dos produtos e a mutabilidade imposta aos equipamentos freqüentemente justificada de maneira simplista pela lei de Moore, donde o novo custa menos e produz mais. Reduzindo não só o custo da mão de obra e propiciando economia em escala, mas também oferecendo soluções mais eficientes no consumo e gerenciamento de energia, matéria prima e mão de obra.

Lei de Moore:

Na década de 60, o co-fundador da Intel Gordon Moore fez uma observação que até os dias de hoje tem validade e é freqüentemente referenciada como lei de Moore. Inicialmente referia-se somente aos circuitos integrados de memória $^{59}$ e depois expandiu sua abrangência aos processadores sem prejuízo de significado. Moore observou que a cada lançamento de circuito integrado, o mais recente possuía o dobro da capacidade de seu predecessor e que normalmente um novo lançamento ocorria de dezoito a vinte e quatro meses após o anterior. Chamou a atenção para, no caso da tendência continuar, um crescimento exponencial da computação. (Computer Dictionary On-Line, Disponível em: http://www.computer-dictionaryonline.org/Moore's\%20Law.htm?q=Moore's\%20Law, Acessado em: Jan. 2007)

Presentemente, a observação de Moore ainda é pertinente. Tomando como exemplo um dos últimos processadores, o Itanium 2, lançado pela Intel em Novembro de 2004, que encerra em seu chip 592 milhões de transistores, cerca de 260 mil vezes mais que os 2300 do processador 4004 lançado em 1971. (INTEL, Microprocessor

Quick Reference Guide, Disponível em: http://www.intel.com/pressroom/kits/ quickreffam.htm\#Itanium2 acessado em: Nov. 2006).

\subsubsection{Um Paradoxo Interessante}

Num tipo de sinédoque indulgente, os próprios equipamentos que representam a base destes universos distintos ilustram esta desinteligência: se feitas as manutenções preventivas e corretivas necessárias, um projetor de cinema

\footnotetext{
${ }^{59}$ Circuitos integrados de memória e processadores são freqüentemente referenciados apenas como Chips.
} 
fabricado na década de 70 poderia ainda hoje operar comercialmente numa sala de cinema. Um computador da mesma época dificilmente encontraria lugar fora de uma sala de museu ou vitrine de colecionador, independentemente de seu estado de funcionamento.

Contrastando com este mercado extremamente ágil, de certa forma aberto, capitalista e muitíssimo competitivo, temos as relações tradicionais da indústria cinematográfica, oligopolistas, lentas, bastante fechadas. Identifica-se este ponto como uma das principais origens dos problemas para implantação do cinema digital.

Pode-se dizer que a indústria cinematográfica entrou num impasse para o qual ainda não conseguiu encontrar a saída. O cinema digital reduziria consideravelmente os custos de distribuição ${ }^{60}$, permitiria o lançamento em maior circuito e reduziria o índice da distribuição informal e pirata ${ }^{61}$. Contudo, esta mesma redução de custos tornaria em parte dos casos até desnecessária a utilização de distribuidores, atualmente ligados de maneira visceral aos grandes estúdios. O produtor poderia fornecer o filme finalizado aos circuitos exibidores, diretamente, economizando os vultuosos recursos de distribuição. Resultaria num mercado mais aberto e retiraria das grandes distribuidoras, e seus estúdios coligados, boa parte de seu poder. Uma mudança de paradigma que ameaça a situação mais confortável vivida atualmente pelos distribuidores.

\subsection{Crise dos Exibidores}

Tornando mais complexa a questão, o setor exibidor ignorou os indícios e as advertências recebidas no final dos anos 90 , que denunciavam a saturação do mercado exibidor americano ${ }^{62}$. Desconsiderando a opinião dos analistas, continuou

\footnotetext{
${ }^{60}$ Neste contexto, distribuição é utilizada com um sentido mais amplo, englobando também a copiagem e masterização.

${ }^{61} \mathrm{O}$ conteúdo no cinema digital é criptografado e com possibilidade de adoção de medidas expiratórias e de auto eliminação.

${ }^{62}$ A advertência fora feita também para o mercado exibidor inglês e divulgada na mídia especializada (Screen International, Jul. de 1997).
} 
com o processo de expansão e abertura de salas, de maneira que o ano de 2000 representou o apogeu da recente crise do setor exibidor nos Estados Unidos.

A instalação de um número excessivo de salas de cinema forçara uma competição ainda mais agressiva e a adoção de uma política autofágica para o granjeamento de espectadores, com a resultante redução de receita. A conseqüência imediata foi a da falência de diversas empresas exibidoras e a sobrevivência de outras tantas, unicamente pelo amparo legal conseguido.

De Luca escreveu em sua tese ${ }^{63}$, "Dos dez maiores exibidores norteamericanos, cinco estavam sob a proteção da legislação falimentar, tentando evitar a bancarrota [...] havia setores da economia que poderiam parecer com os setores eletrônicos, mas não o eram. A afirmativa valia, mais do que nunca, para o setor de exibição cinematográfica que, embora inserida dentro de um conjunto de atividades que estavam passando a ser eletrônicas, independentemente do suporte e meios que utilizasse, representava uma atividade estruturada em um modelo de exploração de serviços pertencente à velha economia". Diante desta realidade, a idéia dos distribuidores de que os próprios exibidores deveriam investir na transformação da estrutura das salas de exibição, para torná-las compatíveis com o cinema digital, não obteve o apoio necessário e não progrediu em absoluto.

Mesmo se a situação dos exibidores fosse completamente oposta: não estivessem em crise profunda e seus cofres transbordassem, considera-se que ainda assim, o setor mostrar-se-ia mais do que receoso em investir algumas centenas de milhares de dólares em uma tecnologia que, além de não ter sido testada e completamente aceita, tem a previsão de vida útil de cerca de cinco anos contra os mais de trinta dos projetores de cinema convencionais utilizados. E, mais significativo inclusive, a um custo dez vezes maior.

\subsection{O Interesse Forasteiro}

\footnotetext{
${ }^{63}$ DE LUCA, L. G. A. Cinema Digital: mudanças e transformações para um novo cinema. 2003. 306f. Tese ( Doutorado em Comunicação e Estética do Audiovisual), Escola de Comunicações e Artes, Universidade de São Paulo, 2003. pg.187
} 
Não bastasse este quadro complexo e a precária situação de mera sobrevivência que o segmento exibidor se encontrava, empresas alheias à indústria cinematográfica, que vislumbravam a possibilidade de diversificação de negócios, agiram no sentido de impulsionar a adoção do cinema digital e sua conseqüente mudança de paradigma de exibição.

A Boeing, tradicional construtora aeronáutica, apresentou planos para estruturar um fundo de financiamento para implantação de sistemas digitais de transmissão e distribuição, que seriam posteriormente arrendados para os cinemas. A Thomson, conglomerado francês de telecomunicações, através de sua recém adquirida Technicolor, firmando um consórcio com a Qualcomm, divulgou um plano de negócios onde implantaria a estrutura de distribuição e receberia uma fração de 0,125 dólares por ingresso vendido.

A essência do modelo tradicional de exploração comercial de um filme pode ser analisada ${ }^{64}$ observando-se a participação de três agentes:

Produtor: responsável por materializar o filme. Aloca recursos, próprios ou não para conferir ao corpus misticum seu corpus mechanicum. Ou seja, transforma a idéia no objeto material; fixa a obra no suporte, geralmente resultando num rolo, ou rolos, de filme $35 \mathrm{~mm}$.

Distribuidor: responsável por fazer com que o filme chegue ao exibidor. É ele quem duplica o rolo original e fica encarregado de distribuir as cópias para o exibidor. Adicionalmente investe na publicidade do lançamento, arrecada junto ao exibidor e repassa as verbas ao produtor, após as devidas deduções.

Exibidor: proprietário do equipamento de exibição e das salas, encarrega-se de programar a exibição dos filmes, administrar a operação de exibição, arrecadar os valores dos ingressos e repassá-los ao distribuidor após as devidas deduções.

\footnotetext{
${ }^{64}$ Nesta análise simples deixaram-se de lado, sem prejuízo do entendimento, as disputas comerciais antes da garantia de exibição, as idiossincrasias do mercado, tais quais a política de bloco, negative pick-up deals e outros fatores que influem na proporção da distribuição da arrecadação.
} 
A remuneração das partes, normalmente uma participação percentual sobre o montante arrecadado com a venda dos ingressos, varia pela influência de vários fatores: legislação local, prática estabelecida no país de exibição, com os acordos firmados, em função da modalidade de financiamento de produção e das despesas variáveis. O Brasil, de maneira semelhante à França e Itália, pratica a remuneração em torno de $50 \%$ para o exibidor, depois de efetuados os descontos autorizados $^{65}$ sobre a arrecadação bruta. $O$ restante será repassado ao distribuidor.

Do montante repassado ao distribuidor, cerca de $47 \%$ da arrecadação, serão descontadas as despesas com copiagem, manutenção, marketing, logística de distribuição, fiscalização de bilheterias e quaisquer adiantamentos de receitas ao produtor que tenham ocorrido. Depois de cobertas todas estas despesas, o distribuidor descontará das verbas recebidas uma porcentagem a título de comissão de distribuição ${ }^{66}$ e repassará o restante ao produtor.

Sintetizando, o exibidor recebe sempre em primeira mão e repassa ao distribuidor que, depois de descontar todas as suas despesas, divide a receita com o produtor. Considerando-se que na variável "custo do exibidor" a componente do custo fixo é maior que a do variável; que para o distribuidor a situação é inversa, com garantia de retorno e que o produtor só recebe depois de cobertas as despesas de distribuição, é possível compreender a força da posição que ocupam os distribuidores e sua conseqüente preocupação com a alteração do paradigma tradicional, mesmo com a desejada redução dos custos de distribuição ${ }^{67}$.

\footnotetext{
${ }^{65}$ Os descontos autorizados englobam ISS e algumas vezes publicidade específica custeada pelo próprio exibidor. No exemplo usaremos $6 \%$ para o total de descontos autorizados.

${ }^{66}$ Esta comissão de distribuição é bastante variada e geralmente é negociada com base nos adiantamentos sobre receitas futuras, direitos de distribuição e risco percebido no projeto.

${ }^{67}$ No artigo publicado no Film Journal International, Maio, 2002, projetava-se uma economia da ordem de $75 \%$ dos 5 bilhões de dólares gastos anualmente com a copiagem e distribuição de filmes.
} 


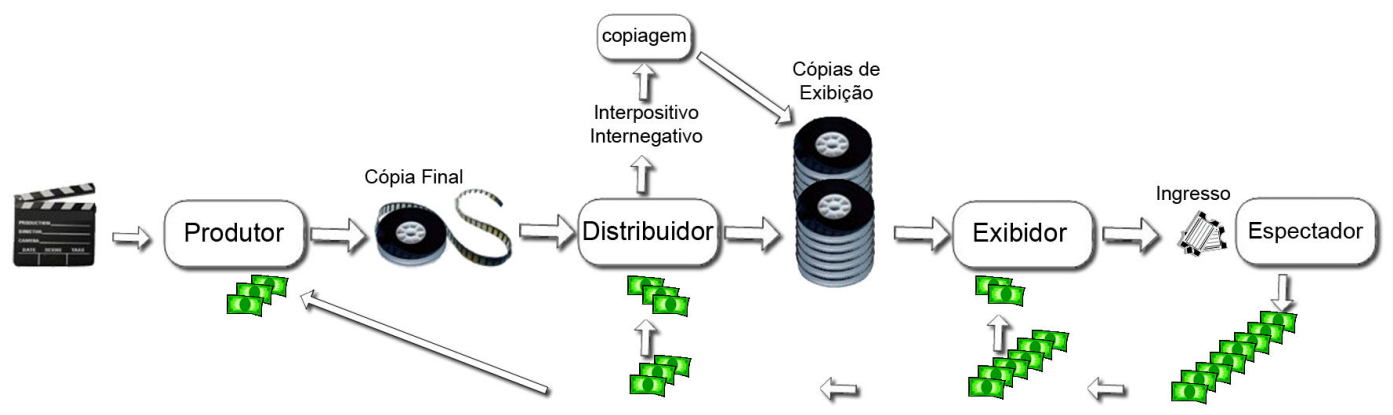

Figura 4.1 - Realização e Remuneração no Cinema

\subsection{A Reação da Indústria}

O conhecimento da força e participação de cada uma das partes no modelo tradicional da indústria permite-nos compreender melhor a aparente esquisita situação na qual, no mesmo ano em que a indústria comemorava excelentes resultados financeiros, com cinco filmes superando 200 milhões de dólares e outros quinze a casa dos 100 milhões, o setor exibidor encontrava-se em meio a uma convoluta reorganização que perduraria por mais de três anos, reduzindo o número de salas, fechando empresas, praticando fusões e vendas, o que resultou numa profunda alteração da situação do setor.

O ano de 2001 fechava com uma estranha e singular dicotomia: a indústria comemorava os melhores resultados financeiros de sua história, mas o setor de exibição via-se combalido. (DE LUCA, L. G. A. Cinema Digital: mudanças e transformações para um novo cinema, 2003. 306f. Tese de Doutorado em Comunicação e Estética do Audiovisual), Escola de Comunicações e Artes, Universidade de São Paulo, 2003, pág. 194.)

Em meio a esta balbúrdia que se encontrava o setor, dando um outro passo no sentido de aproximar-se da indústria cinematográfica e invadindo o território dominado pelos distribuidores, a Boeing anunciou a formação de um 
circuito composto por 3000 salas de cinema, que utilizaria sua tecnologia e seria vinculado a ela. Comunicou ainda que estaria em negociação com produtores para exibir conteúdos alternativos nos cinemas, tais quais shows, concertos, eventos corporativos e esportivos. A resposta dos distribuidores foi imediata, pressionando exibidores e produtores de modo a impedir a concretização de acordos e impossibilitar a perigosa expansão da Boeing sobre seus negócios.

Anunciava-se na Europa a constituição de uma comissão representativa da "cadeia de valor do Audiovisual", produção, exibição e distribuição, que se encarregaria de evitar ingerências institucionais ou externas à própria indústria e da qual o grosso das principais organizações sindicais de exibidores foi signatário: África do Sul, Alemanha, Austrália, Áustria, Bélgica, Canadá, Dinamarca, Espanha, Estados Unidos, Finlândia, França, Holanda, Hungria, Itália, Japão, Reino Unido e Suíça, entre outros.

Pouco tempo depois, em março de 2002, os grandes estúdios e suas respectivas distribuidoras, Disney, Fox, MGM, Paramount, Sony, Universal, e Warner Bros constituíram um consórcio, com o intuito de defender os interesses da indústria, inicialmente chamado de Newco Digital Cinema (NDC) e posteriormente rebatizado como Digital Cinema Initiative (DCI).

Publicações como a (In Focus, jun., 2002, Disponível em: http://www.natoonline.org/infocus/02june/digital.asp acesso em: dez., 2006) demonstram que a criação da $\mathrm{DCl}$ teve uma repercussão positiva, pois se valeu do exemplo desastroso da adoção de sistemas de som cinematográficos digitais, definidos e implantados livre e diretamente pelos fabricantes para legitimar a tomada para si da responsabilidade de assegurar padrões de formato de exibição abertos, seguros, compatíveis e interativos. Esta implantação com padrões definidos pelos fabricantes fora realmente péssima para a indústria, pois resultara em três sistemas de tecnologias distintas, incompatíveis e que ainda hoje exigem gastos com aparelhagem muito maiores do que um único sistema exigiria.

No sítio da Digital Cinema Initiative na rede mundial de computadores, pode-se encontrar seu propósito publicado: 
The purpose of $\mathrm{DCl}$ is to establish and document specifications for an open architecture for Digital Cinema components that ensures a uniform and high level of technical performance, reliability and quality control.

O propósito da $\mathrm{DCl}$ é estabelecer e documentar especificações para uma arquitetura aberta para os componentes do Cinema Digital que assegurem uma performance técnica uniforme e de alto nível, confiabilidade e controle de qualidade (Disponível em: http://www.dcimovies.com/press/ Acesso em: nov., 2006 - tradução nossa).

Justamente pela proposta da $\mathrm{DCl}$ representar os anseios da indústria, os mais variados setores reconheceram sua propriedade, apoiaram sua constituição e Ihe conferiram a "autoridade" para a definição das especificações. Evitando assim a adoção de medidas mais contundentes e agressivas como quando os produtores e exibidores foram pressionados a abandonar as parcerias do modelo de negócios idealizado pela Boeing.

Levantando a Barra

Uma das primeiras ações da $\mathrm{DCl}$ foi a de elevar o patamar técnico mínimo de modo a impedir a adoção de qualquer um dos modelos de exibição digital em testes na época. Para tanto sinalizou uma tendência de adoção de sistemas com resolução $4 \mathrm{~K}$ e como conseqüência, indiretamente rotulou como inadequados todos os protótipos em uso até então, que em média ofereciam uma resolução na faixa de 1.3K. Com esta manobra ganhou tempo para melhor se enraizar no mercado.

Em julho de 2005 a DCl publicou as suas especificações que em seu escopo abrangiam:

Digital Cinema Distribution Master (DCDM): máster de distribuição de Cinema Digital, um conjunto de especificações da estrutura da imagem, do áudio e das legendas;

Compressão da Imagem: especificando O JPEG $2000^{68}$ codificador e decodificador;

Empacotamento: define as exigências para a criação do pacote de dados DCDM utilizando, quando possível, as especificações do $\mathrm{MXF}^{69}$, Material

\footnotetext{
${ }^{68}$ Disponível em: http://www.jpeg.org/jpeg2000/ Acesso em: nov., 2006.

${ }^{69}$ SMPTE 377M: The MXF File Format Specification
} 
eXchange Format e $\mathrm{XML}^{70}$, eXtensible Mark up Language. $\mathrm{O}$ resultado deste processo é o DCP, Digital Cinema Package, Pacote de Cinema Digital;

Transporte: define os procedimentos para o deslocamento do material dos distribuidores até as salas de exibição;

Sistemas da Sala de Cinema: define as especificações de $\operatorname{todos}^{71}$ os equipamentos necessários para a operação de exibição do Cinema Digital nos ambientes típicos das salas de exibição;

Projeção: define as especificações técnicas do sistema de projeção e seu ambiente controlado, junto com as tolerâncias dos parâmetros técnicos segmentados em duas classes: Masterização e Exibição;

Segurança: define as especificações de segurança para uma arquitetura de sistema aberto, com proteção permanente de conteúdo e acesso controlado. (tradução nossa)

Uma vez que o cinema comercial depende em demasia dos filmes oferecidos pelos grandes estúdios - distribuidores -, fabricantes, investidores e exibidores vêem-se obrigados a seguir as especificações da $\mathrm{DCl}$, sob pena de deles não receberem os lançamentos para suas salas, supostamente pela não certificação de seus equipamentos. Sem grandes variações de um ano para o outro, os estúdios integrantes da $\mathrm{DCl}$ representam a imensa maioria da arrecadação da indústria, cerca de $80 \%$.

(De Luca, 2003) reflete sobre a força da DCl e as supostas conseqüências de sua ausência das salas:

"cabe apenas conhecer se as opções de fornecimento de filmes, oferecidas para salas digitais, sem a oferta de títulos pelos estúdios constituintes da $\mathrm{DCl}$, serão suficientes para sua sobrevivência econômica (...) Após um breve período de remessa de cópias para cinemas experimentais, a entrega deste tipo de cópia, hoje, tem diminuído aos poucos. A Columbia, a Disney e a UIP jamais entregaram uma única matriz digital para exibição cinematográfica comercial para os cinemas. E o procedimento dos grandes

\footnotetext{
${ }^{70}$ Disponível em: http://www.w3.org/TR/2006/REC-xml-20060816/ Acesso em: nov., 2006.

${ }^{71}$ Seria mais tarde complementado pela publicação das especificações da NATO - Associação Nacional dos proprietários de Cinema - para exibição em fevereiro de 2006 Disponível em: http://www.natoonline.org/NATO\%20Digital\%20Cinema\%20System\%20Requirements\%20-\%20release\%201-02.pdf Acesso em: Nov., 2006.
} 
estúdios norte-americanos, daqui para a frente, é uma incógnita, a qual influenciará decisivamente no futuro dos cinemas digitais."

\subsection{Diferentes Tipos de Cinema Digital}

Antes mesmo da publicação das especificações, padrões e critérios para a classificação de equipamentos e conteúdo foram adotados pela indústria . Para diferenciar as diversas outras modalidades de exibição digital, estabeleceram uma classificação com base no que rotularam de qualidade ${ }^{72}$ e de adequação de uso: DCinema, E-Cinema e Pré-Show.

\subsubsection{D-Cinema:}

D-Cinema descreve a exibição de conteúdo com qualidade de estúdio, utilizando equipamento que permita uma experiência de visualização igual, ou melhor, que a em película $35 \mathrm{~mm}$. Os equipamentos de armazenamento e projeção são projetados especialmente para utilização cinematográfica. A qualidade de exibição atende aos padrões de alta qualidade da indústria e às expectativas dos realizadores críticos.

Uso: filme longa metragem comercial ${ }^{73}$ ou conteúdo de vanguarda ${ }^{74}$ alternativo

Padrão: em desenvolvimento pelo SMPTE, Society of Motion Pictures \& Television Engineers, e outros.

Equipamento ${ }^{75}$ :

\footnotetext{
${ }^{72}$ Faz-se necessário chamar a atenção para a expressão qualidade rotulada, pois esta atribuição de qualidade nem sempre foi baseada em critérios científicos, ou mesmo indicadores absolutos. Os primeiros sistemas digitais de exibição, ainda em funcionamento em diversas salas de cinema, possuíam resoluções estática e dinâmica bem inferiores às de um computador doméstico comumente utilizado para jogos eletrônicos. Ainda assim, por razões intrínsecas ao marketing, são anunciados como o mais alto nível de qualidade de imagem obtido.

${ }^{73}$ Longa Comercial é utilizado para a versão de Mainstream Feature pela adequação do termo e carência de outro mais amplamente difundido. Em inglês "Mainstream feature content"

${ }^{74}$ A palavra "vanguarda" é aqui utilizada como versão de high-end e significando pioneiro, de técnicas, idéias e conceitos avançados: "High-end alternative content".
} 
Projetor - aprovado pelos Estúdios, resolução de pelo menos $2 \mathrm{~K}$, alto brilho e recursos especiais para cinema de acordo com as especificações do $\mathrm{DCl}$.

Reprodutor - compressão aprovada pelos Estúdios e tipicamente com taxa de transferência de dados superior a $30 \mathrm{Mb} / \mathrm{s}$.

\subsubsection{E-Cinema:}

E-Cinema é um termo que genericamente também descreve cinema digital capaz de exibição de conteúdo cinematográfico. Contudo, tem seus padrões definidos pelo mercado e fabricantes, sem receber a "aprovação" dos Estúdios. Nele, tipicamente os equipamentos de armazenamento e projeção são $\operatorname{COTS}^{76}$, de mercado, e não foram fabricados especialmente para utilização cinematográfica. Apesar do menor custo dos equipamentos, a qualidade pode ser alta, dependendo do conteúdo e do sistema empregado.

Uso: conteúdo alternativo e de produção independente.

Padrão: definido pelo mercado e pelos fabricantes.

Equipamento:

Projetor - alto brilho, alta resolução, para grandes espaços, com saída de projeção maior que 4000 ANSI lumens.

Reprodutor - pode ter qualquer padrão de compressão, inclusive por software e sendo executado em uma plataforma baseada em computador pessoal, com taxa de transferência de dados, tipicamente, de 4 a $20 \mathrm{Mb} / \mathrm{s}$.

\footnotetext{
${ }^{75}$ Por associar equipamento e programas, o cinema digital pede uma diferenciação entre projetor e reprodutor. Projetor é o equipamento propriamente, com suas lentes, lâmpadas e demais componentes, responsável por projetar a imagem na tela. O reprodutor por sua vez é o programa usado para decodificar e interpretar os dados contidos no arquivo e enviar as informações ao projetor, para exibição. Como referência ao processo ou equipamento utilizado para copiar informação, discos e outros, recomenda-se a utilização do termo duplicação. ${ }^{76}$ COTS deriva de commercial off-the-shelf e não tem uma tradução estabelecida em português. Algumas vezes encontra-se simplesmente off-the-shelf. Um equipamento COTS é um equipamento disponível normalmente no mercado. Em informática, e por extensão em áreas conexas, COTS está em oposição à "proprietária”. Uma empresa que desenvolve seu próprio programa editor de imagens usa uma solução "proprietária". Já a que adotou o Photoshop, usa uma solução off-the-shelf.
} 


\subsubsection{Pré-Show:}

Pré-Show engloba o tipo de projetor digital que está sendo instalado em diversas salas em substituição aos projetores de slide ou vídeo utilizados para exibir propagandas e propagandas antes do início da exibição do filme. Composto geralmente por um projetor de baixo custo e, apesar de, junto com o equipamento conexo proporcionar uma exibição pré-show mais empolgante, é considerado como inadequado para exibição de filme longa metragem.

Uso: exibição de propagandas e mensagens.

Padrão: variado - definido pela implementação.

Equipamento:

Projetor - de projetores para apresentação de negócios e baixo custo a projetores para home-theater e médio custo. Normalmente, com saída de projeção menor que 4000 ANSI lumens.

Reprodutor - pode ter qualquer padrão de compressão, inclusive por software e sendo executado em uma plataforma baseada em computador pessoal. Qualidade de DVD.

\subsection{Entrave Político}

À medida que outras fontes foram analisadas, mais se evidenciou a prevalência das questões político-comerciais sobre as de caráter técnico, para a efetiva implantação de um modelo de cinema digital. De um lado as inúmeras vantagens da redução do custo de distribuição, da viabilização da distribuição simultânea sem transferências por meio físico, da não deterioração das cópias, da maior proteção contra a pirataria, entre outras. Em contrapartida, do outro, não se 
descobriu ainda um modelo de negócios que garanta aos grandes estúdios a mesma hegemonia e posição privilegiada que ocupam hoje com a distribuição via película, condição considerada essencial para o efetivo interesse e empenho dos mesmos. Acredita-se que a parcela de espaço perdida pelos distribuidores, caso não tivessem reagido a tempo, seria ocupada quase que integralmente pelos exibidores.

Com a publicação das especificações da $\mathrm{DCl}$, os distribuidores encontraram uma ferramenta para, em certo grau, diminuir as ocorrências da exibição digital sem a participação dos distribuidores. Uma vez que a Digital Cinema Initiatives representa o interesse destes grandes estúdios e a não certificação do exibidor por suas especificações proporciona o pretexto para não lhe disponibilizar filmes, os grandes estúdios conseguiram, de certa forma, conservar seu poder.

A edição de abril do Screen Digest ( Screen Digest, 2007) reporta que ao passo que os Estados Unidos aceleram a implantação dos cinemas, a europa, em geral, ainda pondera. Apresenta ainda gráficos que mostram que o número mundial de salas de cinema digital instaladas é de 2996 e que mais de 2000 delas encontram-se nos EUA.

Num momento em que a adoção da exibição digital ainda não atingiu 4\% do mercado, conseqüência da notória e anunciada obsolescência dos equipamentos eletrônicos e de tecnologia de ponta, $10 \%$ das salas com exibição digital instalada encontra-se com seus equipamentos obsoletos, pois estes projetores digitais de 1.3K não se enquadram na definição de d-cinema e muito menos das especificações da $\mathrm{DCl}$. Complementarmente, os desejados equipamentos de $4 \mathrm{~K}$, que tendem a tornar-se padrão de mercado, são encontrados em apenas 18 salas no mundo todo.

\subsection{Cinema Digital - e Seus Diversos Significados Alternativos}

Mesmo com os esforços reguladores da $\mathrm{DCl}$, atualmente, os significados de exibição e distribuição digital não são os primeiros que vêm à mente quando a expressão Cinema Digital é ouvida. De maneira informal e nos bastidores, aqueles que não estavam tão sujeitos à pressão do consórcio, pelas suas conversas, 
palestras e publicações, mesmo que de maneira inconsciente, fizeram com que o cinema digital tomasse adicionalmente o significado de cinematografia digital. Hoje, cinema digital, como sinônimo de cinematografia digital, é utilizado por importantes membros da área, formadores de opinião, e encontra lugar em muitos textos acadêmicos, artigos e outras publicações.

Como se constata no texto de Henry Jenkins, diretor do programa do MIT de Estudos Comparativos de Mídia, em seu artigo "Quentin Tarantino's Star Wars?: Digital Cinema, Media Convergence, and Participatory Culture":

Not surprisingly, the works of these "video store filmmakers" have been deeply influential on the emerging generation of amateur digital filmmakers $(\ldots)$

This cyclical process has only accelerated since the box office success of The Blair Witch Project, which presented itself as an amateur digital film (albeit one which got commercial distribution and challenged Phantom Menace at the box office in the Summer of 1999)

Sem causar surpresas, os trabalhos destes "cineastas de vídeo-locadora" têm grande influência na emergente geração de cineastas digitais amadores $(\ldots)$

Este processo cíclico apenas acelerou desde o sucesso de bilheteria de A Bruxa de Blair, que se apresentou como um filme digital amador (mesmo um que recebeu distribuição comercial e rivalizou A Ameaça Fantasma nas bilheterias, no verão de 1999) (tradução nossa)

Em sua dissertação de mestrado (MORETTI, M., Cinema Digital no Brasil: qual o estado desta arte, 2002) escreve:

O Cinema Digital é uma nova forma de realização cinematográfica, que faz uso exclusivamente das tecnologias digitais e de computação gráfica. (...)

A Nova Era do Cinema Digital

Enquanto a computação gráfica ganhava terreno no campo das superproduções milionárias de Hollywood, outra trilha estava sendo aberta pela tecnologia digital no lado oposto do espectro cinematográfico. Em 1995, um grupo de cineastas dinamarqueses lançou um manifesto para a realização de filmes não-comerciais que pretendia se opor ao modelo de cinema hollywoodiano. (...) 
No Brasil, o primeiro filme realizado com as novas tecnologias digitais foi o Mater Dei (2000).

Ou ainda no texto de Tom Harris, publicado pela How Stuff Works:

Elements of Digital Cinema

Digital cinema is simply a new approach to making and showing movies. The basic idea is to use bits and bytes (strings of $1 \mathrm{~s}$ and $0 \mathrm{~s}$ ) to record, transmit and replay images, rather than using chemicals on film.

Elementos do Cinema Digital

Cinema Digital é simplesmente uma nova abordagem do fazer e exibir filmes. A idéia básica é usar bits e bytes (seqüências de 1s e 0s) para gravar, transmitir e exibir imagens, ao invés de utilizar produtos químicos em uma película. (tradução nossa)

Como visto nos exemplos acima, os três autores, independentemente do teor e da importância do texto amostrado, utilizam a expressão Cinema Digital com o significado de cinematografia digital: captação digital das imagens. O texto de Harris, tradicionalmente enciclopédico, fornecendo definições e conceitos para o rápido entendimento dos assuntos, chega a montar uma imagem mental simplificada de que o cinema digital é a simples substituição do registro químico pelo digital.

A existência de inúmeras interpretações para cinema digital não constitui grande obstáculo para o estudo, desde que fique claro o entendimento manifestado pelo autor, uma vez que a expressão acaba acomodando-se à qualquer etapa da realização de um filme.

(LONG, B.; SCHENK, S ,2000) na página de introdução de seu livro "The Digital Filmmaking Handbook", relatam uma experiência realizada "há alguns anos ${ }^{77 \text { " }}$ na qual o ator Spalding Gray passou um dia em Los Angeles, seguido por uma equipe de vídeo, perguntando aos transeuntes, selecionados aleatoriamente, se estes poderiam contar-Ihe um pouco sobre o filme que estavam escrevendo. A quase totalidade das respostas foi: "como sabia que eu estava escrevendo um filme?". Ou seja, o desejo de fazer um filme, ser descoberto, tornar-se um escritor, produtor, ou diretor, estava presente nos entrevistados.

\footnotetext{
${ }^{77}$ A data exata em que durou o experimento não foi publicada junto com os resultados.
} 
A tradicional estratégia dos grandes estúdios de elevar o padrão técnico mínimo para reduzir o número de possíveis concorrentes e manter o mercado mais fechado, pode ter sua eficiência reduzida pela utilização de equipamentos digitais para a captação de imagens, edição e mesmo projeção. A prática do tipo de cinema digital que encontra correspondência na supracitada definição de Tom Harris.

Acredita-se que um dos segmentos a beneficiar-se deste novo modelo de produção cinematográfica em que a película é substituída pela informação eletrônica, binária, independentemente do suporte de fixação - discos de computador, fitas digitais, DVDs, etc... - seja o do circuito-de-arte.

São diversos os fatores que contribuem para esta condição mais favorável:

- a não dependência dos distribuidores e seus grandes estúdios;

- salas de exibição de, na média, dimensões mais reduzidas;

- características técnicas do material produzido que exigem menor capacidade de processamento e armazenagem dos servidores do sistema de exibição;

- maior aceitação do público deste segmento de material em tecnologia alternativa ou que não esteja absolutamente alinhada com o ditame do cinema hollywoodiano.

Independentemente da acepção de Cinema Digital empregada, este novo paradigma de produção cinematográfica traz consigo três promessas: apresentar custos menores que os do modelo tradicional, resultar num maior número de realizadores em potencial e, como conseqüência das duas primeiras, fortalecimento de um mercado alternativo latente. 


\section{Modelo de Tecnologia Alternativa para Film Transfer}

\subsection{Avança a Convergência, Ajusta-se o Modelo}

A convergência continua e a Internet, o vídeo SD, o HD e a película estão fundindo-se na forma de mídia digital, dados binários armazenados, transportados e acessíveis em uma variedade de suportes diferentes. Cada vez mais se populariza entre os realizadores a idéia de se produzir apenas um master digital, que tomado como matriz origina as cópias finais nas diversas mídias para lançamento - DVD, videotape, película.

Neste momento de transição entra em cena um outro agente, uma espécie de facilitador, que são as empresas que auxiliam na migração da exibição em película para a digital. Pelo balanço do ano de 2006, constatamos que as empresas de maior expressão no mercado, no papel de facilitadoras, são a AccessIT, XDC e Alliance Digital Cinema (Screen Digest, abr., 20007).

A mudança de paradigma é tal que os anos de conhecimento acumulados pelos profissionais do cinema precisam ser cuidadosamente readaptados à nova realidade, correndo o risco de se tornarem inúteis, tais quais os de profissionais de outrora frente a mudanças que alteraram significativamente os modelos de então.

Apesar das previsões feitas em meados dos anos 90 das televisões ficarem mais inteligentes, interativas, e dotadas da capacidade de comunicação pela internet não terem se concretizado, alguns passos neste sentido foram dados, e, ainda que deslocado no tempo, as tendências ainda apontam para um resultado próximo. Entretanto, não obstante as evidentes mudanças na tecnologia de apresentação da imagem televisiva, do aumento considerável de resolução estática, do tamanho da tela, da maior qualidade percebida da imagem e redução das dimensões físicas do aparelho receptor, numa breve análise, a televisão ocupa o 
mesmo papel na sociedade e sua relação com o telespectador é a mesma de décadas atrás.

A interatividade através da rede, via de regra, é realizada através dos computadores, que com sua constante evolução tecnológica, tem oferecido cada vez mais recursos aos usuários. Não são raros os casos em que os tradicionais televisores da sala cederam seu lugar a um grande monitor de LCD, que de um computador a ele conectado, com qualidade muitíssimo superior à da televisão, recebe as imagens e sons de mídias compartilhadas pela internet, publicadas em DVD, CD, HD ou ainda recebidas pelo cabo da antena ${ }^{78}$.

As previsões não foram tão acertadas em especial quanto à exibição televisiva, onde se preconizava que os estúdios adaptariam seus modelos de produtores-exibidores para o de propagadores de conteúdo, permitindo o florescimento de pequenos produtores. As grandes empresas, especialmente quando estabelecidas em posição dominante e confortável num determinado mercado, demoram a adotar soluções que alterem em muito sua já conhecida e dominada dinâmica de trabalho.

Em um artigo sobre mudança de cultura corporativa, (GETSINGER, L.) escreve:

[...]The failure to adapt is primarily driven by this fear of change. Change strikes fear in the hearts of all who are affected, as they are leaving the known for the unknown. The natural response to change is resistance, and when change does happen, certain individuals will employ slowed down implementation in hopes that it will go away. Today, employing such tactics positions us to become obsolete. Today, change is not only critical to remaining competitive, but to staying in business. (Company Culture Change, GETSINGER, Disponível em:http://www.bta.org/i4a/pages/Index.cf m?pagelD=2434)

O fracasso em se adaptar é primariamente conduzido por este medo de mudar. Mudanças enchem de medo o coração de todos os que são afetados, uma vez que abandonam o conhecido pelo desconhecido. A resposta natural à mudança é a resistência e, quando as mudanças realmente acontecem, alguns indivíduos implementarão implementações

\footnotetext{
${ }^{78} \mathrm{O}$ cabo da antena é empregado com o significado de cabo de recepção de imagem de transmissão televisiva, seja oriundo da antena propriamente ou do fluxo da tv por cabo, sem prejuízo de significado.
} 
retardadas na esperança de que as mudanças passem. Hoje, empregar estas táticas posiciona-nos rumo à obsolescência. Hoje, mudança não é apenas crítico para permanecer competitivo, mas para continuar no mercado. (tradução nossa)

As novas dinâmicas apontam para uma estrutura não como a tradicional pirâmide onde o conteúdo é produzido no topo e distribuído para a base, pois é mais do que sabido que uma das características da internet é flexibilizar as estruturas muito rígidas e lentas, em especial as que possuem hierarquia fornecedorconsumidor muito rígida. Uma analogia que contrasta claramente com o esquema em forma de pirâmide é o da tigela de espaguete ${ }^{79}$ onde todos têm a capacidade de desempenhar os papéis de fornecedores e consumidores, ao mesmo tempo, e em várias direções.

Um fenômeno que ilustra claramente este espaguete é o alastramento dos blogs, onde cada editor publica seu conteúdo compartilhando-o com leitores de mesma mentalidade e ao mesmo tempo consome conteúdo de diversos outros editores-leitores. Ganha audiência e com isso a possibilidade de até receber uma remuneração para divulgar suas idéias. Os blogs ao migrarem para a forma sonora originaram os podcasts e, posteriormente, a capacidade de transmitir e receber imagens amplamente, ou mesmo armazená-las em servidores de compartilhamento de vídeo tais quais o youtube, geraram os vlogs.

Estas iniciativas ilustram a dinâmica acelerada da convergência e, uma vez mais, sugerem um meio de produtores independentes e pequenos realizadores distribuírem suas obras. Podemos concluir que a inexistência de um modelo de negócios reconhecido para monetizar ${ }^{80}$ as pequenas produções retarda a adesão dos grandes exibidores. Entretanto, dada a velocidade e o estágio dos desenvolvimentos, tudo indica que os esforços serão no sentido de capitalizar sobre as pequenas exibições ao invés de tentar extinguí-las.

\footnotetext{
${ }^{79}$ A imagem da tigela de espaguete foi popularizada por Jonathan Oxer, que atua como diretor técnico no mercado de produção audiovisual.

${ }^{80}$ Monetizar é um termo criado pelo marketing e administração que significa "ganhar dinheiro com".
} 


\subsection{Decisão do Formato de Exibição}

$\mathrm{Na}$ atual conjuntura, de maneira análoga aos modelos convencionais de produção, o formato de captação e exibição, o caminho e destino da obra, devem ser considerados nas fases anteriores à produção, preferencialmente, na de desenvolvimento.

Um dos grandes benefícios decorrentes da pós-produção digital, nos mais variados modelos de utilização do intermediário digital, é o da possibilidade da geração de múltiplos formatos na saída, sem a exigência de complicados ou demorados processos de conversão, a um custo mais baixo. Este é um dos principais indicativos de que, até o aparecimento de uma maneira mais eficiente, o DI oferece os melhores benefícios se adotado nas produções dos mais variados tamanhos e recursos.

Destinado a mídias múltiplas, o pioneiro exemplo da série da HBO "Band of Brothers" efetuou a captação em película $35 \mathrm{~mm}$ e, depois de digitalizar as imagens para o padrão $2 \mathrm{~K}$, realizou toda pós-produção digitalmente, preparou 0 master digital e gerou cópias vídeo SD, HD e película $35 \mathrm{~mm}$. O mais importante é que demonstrou que o espectador não vê perdas de qualidade nestas imagens em relação às obtidas pelo processo convencional e que há inúmeras vantagens em se manter a imagem desprovida de corpo, manipulando-a na forma de bits.

Consideramos que os modelos que utilizam o intermediário digital, o DI, para a pós produção apresentam maior capacidade de adaptação, melhor escalabilidade, maior potencial para a redução de custos e flexibilidade de saída. Desta forma, o modelo alternativo para o film transfer sugerido, parte do presuposto que a pós-produção será realizada através de DI, mostrando-se mais adequado nestas condições. Filmes já acabados ou em forma digital incompatível com as especificações do intermediário digital adotado, poderão também se beneficiar deste modelo alternativo, porém devem passar ser ingeridos e compatibilizados com o DI, tal qual numa remasterização. 


\subsection{Tipos de Transfer}

São diversos e bastante variados os formatos de saída para exibição: Quarter-CIF, VHS, NTSC, Pal e suas variações, Secam, S-Vídeo, VCD, SVCD, SDTV, DVD, HDTV, HD DVD, Blue-Ray, D-Cine 1.3K, Academy 2K, D-Cine 2K, Full Aperture $4 \mathrm{~K}$, película $8 \mathrm{~mm}, 16 \mathrm{~mm}, 35 \mathrm{~mm}$, Maxivision $48^{81}, 65 \mathrm{~mm}$, IMAX entre outros. Este processo de saída, preservando o termo originado com o telecine, o transfer de filme para fita de vídeo - tape -, é denominado simplesmente transfer ${ }^{82}$, sendo que cada formato exige processos e equipamentos específicos.

Abaixo se encontram os três principais tipos, classificados pela característica de saída, não atrelados à mídia, se vídeo, película cinematográfica ou master digital.

\subsubsection{Tape Transfer}

O transfer para fita de vídeo é o mais simples de ser obtido e não representa custos ou dificuldades significativas para a realização. Os dados armazenados no sistema, se já adequados ao suporte final, são simplesmente repassados a um gravador de vídeo conectado ao equipamento que os registra em fita.

Para os casos em que o material armazenado não se encontra em formato compatível com o destino, há uma fase anterior à gravação do material, conhecida por render. Nela, os frames não entrelaçados e sem compressão armazenados no DI são recalculados para que possuam as mesmas características do suporte destino, envolvendo à definição, resolução estática, compressão,

\footnotetext{
${ }^{81}$ Maxivisio 48 é um formato que otimiza significativamente o uso do filme $35 \mathrm{~mm}$. Concebido em 1992, baseiase no princípio de otimizar o uso da área do negativo e melhora a resolução dinâmica ou temporal do filme. Para tal, utiliza um sistema diferente de perfurações e roda a 48 quadros por segundo, apresentando movimentos muito mais suaves e dando mais liberdade criativa ao realizador. Adicionalmente, também em conseqüência da furação diferenciada, consome $25 \%$ menos negativo que o padrão $35 \mathrm{~mm}$ de quatro furos.

${ }^{82}$ Muitas vezes é utilizado o suporte final seguido do termo transfer. ie: film transfer é gerar película como produto final.
} 
entrelaçamento, aspect ratio, resolução dinâmica e sistema de cor - uma adequação ao padrão de saída.

\subsubsection{Film Transfer}

O transfer para filme ${ }^{83}$ pode ser entendido como a transferência de arquivos raster ${ }^{84}$ contendo as imagens dos fotogramas da obra - os do DI, por exemplo - para um periférico que as sensibiliza numa película fotográfica que é posteriormente revelada em laboratório fotográfico. A escolha de se imprimir a cópia em internegativo para distribuição ou uma cópia final para composição com o som ótico e posterior duplicação pelos métodos usuais varia em função do projeto, características dos periféricos de saída e do orçamento.

As soluções e equipamentos para o film transfer, independentemente do princípio, possuem uma característica em comum: ao término do transfer, tal qual na fase de produção no set de filmagens, o rolo de película sensibilizada precisa ser enviado ao laboratório fotográfico para revelação.

Apesar da última etapa de um processo envolvendo intermediário digital para projeção em filme ser, via de regra, química no laboratório e existir degradação de imagem decorrentes dos processos químicos, de sujeira, da manipulação e dos danos à película, ainda assim, face ao menor número de passes e sensibilizações, consegue-se com a utilização de DI a maior qualidade de imagem para exibição em película.

Ademais, o conforto de se enviar ao laboratório as referências de cor utilizadas no filme para assegurar que ao ser revelado apresente as mesmas cores idealizadas pelo diretor de realizador e, principalmente, no caso de um imprevisto danificar irreparavelmente, pode-se gerar um novo negativo com base nos dados do DI.

\footnotetext{
${ }^{83} \mathrm{Em}$ algumas publicações encontra-se o termo film recording ou o mais genérico film-out. O film print quando se referindo ao transfer indica a impressão da cópia internegativa para duplicação, ou seja, uma que engloba as legendas e som ótico.

${ }^{84}$ Um arquivo tipo raster é aquele em que há informação de cada pixel.
} 
A figura abaixo apresenta um detalhamento de módulos internos ao DI. Pode-se observar que a utilização de meta-data nas alterações da imagem constitui uma das grandes vantagens do DI, pois as imagens originais, tais quais ingeridas, permanecem inalteradas e as modificações são reversíveis.

O render realizado na fase anterior à saída da imagem toma como base a imagem originalmente ingerida e, seguindo os registros no arquivo de meta-data acumulado, nela aplica transformações para gerar uma imagem contendo todas as alterações. É esta resultante que é enviada ao periférico de saída pra película.

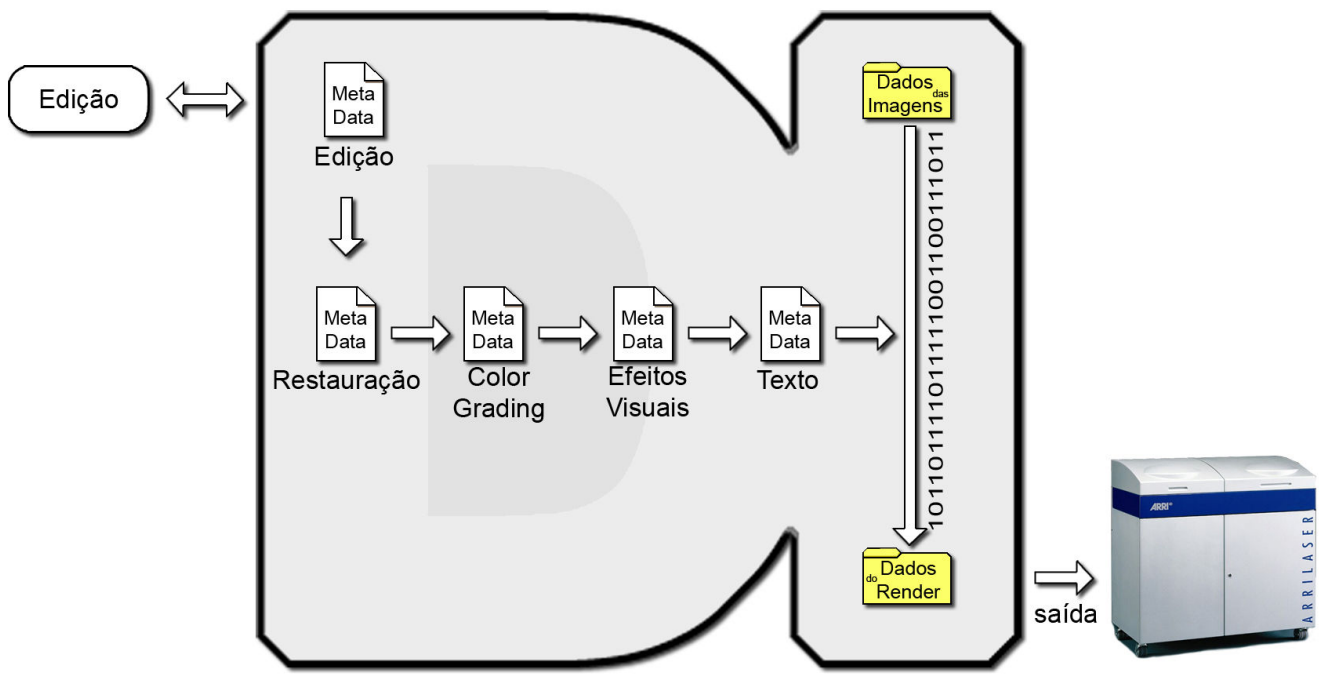

Figura 5.1 - DI e Saída para Film Recorder

\subsubsection{Film Recorder}

O film recorder é um periférico de saída utilizado para transferir fotograficamente imagens para a película e, apesar de algumas variações, tem o mesmo princípio de funcionamento.

CRT e Laser - Estes equipamentos, tomando como base uma imagem em arquivo raster enviado pelo computador, sensibilizam a película virgem emitindo luz de um tubo de raios catódicos - CRT ou feixe laser. Junto com o obturador, o 
tracionador e os defletores de raios do tubo, ou do laser, o circuito de controle, posiciona filtros para as cores primárias montados em um disco. Os raios de luz, ao atravessarem cada um dos filtros, sensibilizam a película para aquela cor. Dos experimentos realizados com film recorders de CRT colorido, concluiu-se que sua qualidade de saída era consideravelmente inferior. Já os recorders por feixe de laser são mais precisos que os CRTs. Um dos mais comuns é o Arrilaser.

O Kinescope, que era um processo analógico, tratava-se de uma espécie de telecine invertido, um processo que resumidamente consistia em filmar em película um pequeno monitor de vídeo de alta resolução, compensando no obturador as diferenças na resolução dinâmica e no ganho dos feixes as da latitude e color space. As imagens geradas não apresentam alta qualidade para os padrões hodiernos, mas seu custo é menor que o transfer a laser. Vem cedendo lugar a tecnologias mais avançadas, baseadas em circuitos digitais e são poucas as produções que ainda o utilizam.

LVT - Uma outra tecnologia é a de Light Valve Technology - LVT empregada pela Kodak e que se vale de moduladores eletro-óticos proprietários para controlar a quantidade de luz de cada um dos raios vermelhos, verdes e azuis que atingem o filme. O princípio é o mesmo, entretanto, o LVT produz as imagens de maior qualidade e resolução quando comparado aos outros, pois é capaz de resolver 120 pixels por milímetro, o que é maior que a resolução espacial de um filme de $35 \mathrm{~mm}$.

DLP - Uma solução recente usa os Digital Light Processor DLPs fabricados pela texas para controlar a luz incidente na película. Valendo-se de Digital Micromirror Devices DMDs para um ou mais pixels, os DLPs produzem imagens de maior resolução que o número de DMDs empregados e acredita-se produziram imagens de altíssima qualidade. Contudo, não há ainda referências de comparação destes equipamentos com outros de mesma geração. O film recorder Cinevator é um dos que utilizam esta tecnologia.

EBR - Os equipamentos Electron Bean Recorders EBR utilizam um feixe de elétrons, tal qual no interior de um CRT, para sensibilizar uma película fotográfica virgem para cada uma das luzes primárias. Estas películas são depois combinadas 
oticamente para produzir a imagem final. É um processo que envolve a combinação ótica de película, várias instâncias de negativo e que por isso foi quase que totalmente abandonado em função de outros mais eficientes.

Com a consolidação do DI e da pós-produção digital, algumas empresas tem investido em pesquisa para o aprimoramento da transferência de dados para a película. Apesar de pequenas variações e alguns sistemas proprietários, pode-se admitir que, apesar das diferenças dos modelos, o princípio é semelhante, sensibilizar a película de maneira controlada.

\subsubsection{Data Transfer}

Indiscutivelmente, o processo que retém a imagem em sua melhor forma, não degradando o que foi ingerido e possibilitando a exibição com a maior qualidade, é o de data transfer - a transferência de dados do sistema DI para uma outra mídia - que pode gerar cópias para arquivamento, conversão para outra mídia digital tal qual o DVD ou a preparação dos masters de distribuição de cinema digital DCDM pelas especificações da Digital Cinema Initiatives.

Por tratar-se da transferência de bits de uma mídia para a outra, não há comprometimento da informação, nem degradação da imagem. Se acessíveis os dados, a imagem estará tal qual quando gerada, independentemente de ter sido exibida uma infinidade de vezes. Por analogia, o espectador ao assistir, em sua casa, o mesmo DVD pela centésima vez, não perceberá degradação na imagem decorrente do desgastes dos bits. Se legível da mídia, a informação permanece inalterada.

Os DCDMs são combinados com o som é fechados em um pacote de distribuição de cinema digital DCP, também pelas especificações da $\mathrm{DCl}$. A utilização do suporte digital ponta a ponta traz inúmeras vantagens para a produção. A qualidade de imagem é limitada apenas pelo suporte físico utilizado para visualizala. Desta forma, dada a evolução da tecnologia, em especial o desenvolvimento de processadores cada vez mais rápidos, a projeção digital tende a ser adotada em 
larga escala, assim que os forem acomodados os interesses comerciais e a difusão de equipamentos de maior tecnologia obtida.

A Sony já equipou 18 salas de cinema no mundo com seu projetor SRXD de $4 \mathrm{~K}$, o de mais alta resolução no mercado, e uma reportagem publicada na Variety, em novembro de 2007, traz uma análise feita pela empresa inglesa Dodona Research que, uma vez que considera na iminência de solução a maior parte das questões comercias e de tecnologia, prevê que em 2013,50\% das salas de cinema no mundo terão migrado para a exibição de cinema digital.

\subsection{Definindo o modelo Alternativo}

\subsubsection{Premissas}

Não é novidade que o cinema mundial, como um todo, não desfruta do mesmo vigor financeiro que o cinema americano, comumente referido por indústria cinematográfica. O país é a maior economia do mundo e sua indústria de entretenimento e recebe muitíssima atenção da maioria de seus governantes, não por trazer as maiores divisas, mas, principalmente, pela implicação política da propagação em larga escala dos filmes americanos.

Muito pela voracidade do mercado de entretenimento, a opção de adotar soluções certificadas, testadas e aprovadas pela indústria, é restrita a alguns poucos. Os preços praticados para os equipamentos high-end ${ }^{85}$, de vanguarda, da indústria cinematográfica são muito altos mesmo pra a produção comercial de países desenvolvidos. Investimentos neste sentido são cuidadosamente estudados e feitos esporadicamente.

\footnotetext{
${ }^{85}$ High-end refere-se aos equipamentos considerados da mais alta tecnologia e é sempre uma referência dependente do contexto.
} 
Diante desta realidade, o produtor independente, o artista realizador e o estudante, ícones do cinema carente de verbas e recursos, enfrentam grandes dificuldades para produzir filmes nos padrões comerciais, ficando muitas vezes à mercê das políticas governamentais, dos incentivos legais ou relegados aos suportes de segunda categoria.

A premissa para a definição do modelo alternativo leva em conta a evolução tecnológica e a freqüente disponibilização de equipamentos de alta tecnologia ao consumidor comum, que quando combinados ou mesmo alterados, podem desempenhar outra função que não a para qual foram originalmente desenvolvidos.

\subsubsection{Opção pelo COTS}

Equipamentos comumente encontrados no mercado são também chamados de equipamentos de prateleira e, em algumas situações, apresentam desempenho próximo a soluções proprietárias e específicas. A indústria de hardware e software, percebeu que o custo para se adotar uma solução alheia pronta, é muitas vezes menos do que o de desenvolver sua própria. Desta maneira, comercializam-se desde linhas de código de programação, até componentes e equipamentos. Esta filosofia de integração é conhecida como COTS, sigla derivada da expressão "Comercial Of The Shelf" - que indica os produtos normalmente disponíveis no mercado.

Um estudo do departamento de defesa americano no final da década de 90 mostrou que parte dos equipamentos usados pelo governo poderia ser substituída sem prejuízo de funções por equipamentos COTS, com significativa economia e, em muitos departamentos é obrigatório a compra de produtos COTS em oposição ao emprego de compradores, licitações e demais ferramentas burocráticas.

A proposta do modelo alternativo leva em conta a filosofia COTS, a rápida evolução dos equipamentos, a padronização dos protocolos de comunicação e a 
possibilidade de integrá-los em uma solução de film transfer que não custa centenas de milhares de dólares.

\subsubsection{Resolução do Transfer}

A primeira e maior questão a ser respondida é a de qual a resolução desejada para o transfer. No topo da escala temos os moderníssimos equipamentos que transferem imagens a $4 \mathrm{~K}$ para a película $35 \mathrm{~mm}$ e saindo de cena os antigos kinescopes com resoluções, que mesmo duplicadas, não ultrapassavam $1 \mathrm{~K}$.

A rápida evolução da tecnologia de informação e dos equipamentos, que se valem de processadores e outros componentes eletrônicos, confere uma característica deveras volátil aos números absolutos derivados das nossas conclusões. Contudo, o processo de definição pode ser empregado para encontrar os novos números em um contexto futuro - deve ser entendido como relativo e fixado ao panorama do início de 2007.

Os primeiros projetores e cinema digital apresentavam, rotulados como experimentais, uma resolução estática em 1.3k - SXGA ${ }^{86}, 1280$ x 1024 pixels padrão considerado baixo para os dias de hoje, mas que ainda é encontrado operando atualmente e foi computado na contagem de salas de cinema digital feita da pesquisa publicada pela Screen Digest, mesmo estando em desacordo com as especificações da DCl.

O padrão de 2k para a exibição digital é o predominante. Paulatinamente o 1.3k está saindo de cena e, no outro extremo, o 4k só está presente em 18 salas no mundo. Um dos principais argumentos de que o filme é insubstituível para a captação é a de que os sistemas digitais não conseguem a mesma resolução estática que o negativo. Forte argumento, pois um negativo original $35 \mathrm{~mm}$, quando corretamente exposto, consegue registrar cerca de 6000 linhas. Contudo, uma vez que a película sofre degradação a cada etapa do processo químico, incluindo a revelação, geração da cópia final do negativo montado, geração do interpositivo, do

\footnotetext{
${ }^{86}$ SXGA é uma sigla originada de Super eXtended Graphics Array, a evolução do XGA de 1990.
} 
contratipo e da cópia de exibição, quando chega à tela do cinema, chega a conter em alguns casos apenas 1800 linhas. Este foi um dos argumentos utilizados na proposição do $2 \mathrm{k}$ como padrão mínimo da indústria para receber a certificação da $\mathrm{DCl}$.

Considerando que uma maior resolução implica na redução de opção de escolha de equipamentos e risco de extrapolar o conjunto que abrange os COTS, maior custo para a integração do sistema, afetando diretamente os outros componentes, concluímos que um valor equilibrado de escolha de resolução seria em torno do $2 \mathrm{k}$. Faria muito pouco sentido investir em um sistema com premissa de alternativo e que apresentasse maior resolução do que os empregados no cinema comercial. Complementarmente, com a popularização do vídeo e dos projetores full HD, uma cópia com menor resolução estática que o vídeo não se apresenta como uma solução interessante, pois haveria perda ao se transferir imagem oriunda do vídeo para o filme.

O sistema DI empregado para o transfer deve conter, semelhante às especificações de suas contrapartes de mercado, um sistema de arquivamento de imagens não comprimidas, raster e com pelo menos 24 bits de cor, representativo dos fotogramas a serem transferidos. Consideramos o formato Tagged Image File Format, TIFF, adequado pois possui amplo suporte e é interpretado por boa parte dos programas de edição. Imagens no padrão $2 \mathrm{k}$ poderiam ser gerenciadas em um computador, compatível com IBM-PC, sem que fossem necessários periféricos não contemplados no COTS.

Cada um dos arquivos TIFF do DI armazenará um fotograma a ser transcrito. De maneira a comportar o padrão $2 \mathrm{k}$ e considerando a disponibilidade dos periféricos de exibição, monitores, o formato WQXGA, 2560x1600, mostra-se adequado, pois monitores de maior resolução WQUXGA ${ }^{87}$ tornaram-se mais escassos. Nossa pesquisa constatou nenhum projetor DLP ou LCD que alcançasse resolução próxima do WQXGA e pudesse ser enquadrado na filosofia COTS.

\footnotetext{
${ }^{87}$ WQXGA - Wide Quad eXtended Graphics Array, 2560x1600. WQUXGA - Wide Quad Ultra eXtended Graphics Array - 3840x2800 - formato no qual a Toshiba programou o lançamento de um monitor para meados de 2008. (Toshiba press release - disponível em: http://www.toshiba-sol.co.jp/news/detail/071101-2.htm acessado em: nov de 2007)
} 


\subsubsection{Color Space}

A diferença entre a escala do color space ${ }^{88}$ do sinal eletrônico, que é linear, para a do fotoquímico da película, logarítmico, exige que sejam efetuadas conversões quando da utilização de imagens provenientes de um sistema no outro. Concluímos, face à natureza dos dados armazenados e das práticas semelhantes empregadas na estrutura de produção digital, que a maneira mais produtiva de se realizar a conversão é aplicar uma Look Up Table LUT no momento de sensibilizar a película.

A LUT apresenta a vantagem do trabalho com meta-data, da preservação da imagem inalterada, pode ser compensada para refletir o desgaste do sistema. Contudo, um lado negativo é o de que, apesar da otimização matemática de sua construção, requer empenho para o refinamento manual. Ou seja, compreende parte de um processo empírico de ajuste das referências dos dois color spaces. Ponderadas as vantagens e desvantagens, consideramos que o emprego de uma ou mais LUT, seja para acomodar variações nas películas de diferentes marcas ou a natureza das imagens, é uma solução interessante e viável.

\subsubsection{Harware e Software}

Para o processamento dos dados e controle do sistema, não são necessários computadores de vanguarda ou repletos de periféricos. Um sistema composto por um processador de núcleo-duplo, tal qual o Intel Core 2 duo E6850, montado em uma placa mãe que ofereça RAID 5, onboard, SATA para 6 discos e cerca de 2GB de memória ram, uma GPU destinada a jogos, intermediária, tal qual a geForce 8800 GTS, estimamos seja suficiente.

\footnotetext{
${ }^{88}$ Espaço de Cores é uma tradução bastante difundida de color space. Contudo, para os termos técnicos, preferimos utilizar o inglês, quando não há prejuízo de entendimento.
} 
O sistema operacional escolhido seria o windows xp, pois, infelizmente, alguns dos softwares necessários á implementação não estão disponíveis em linux. A base de computadores rodando linux, destinados à produção audiovisual, tem crescido significativamente e, num futuro não muito distante, acreditamos terá a disposição uma gama tal de softwares que não será mais justificada a instalação em windows.

O principal software para a operação neste modelo teria as características de um visualizador de imagens, seria capaz de se comunicar com uma câmera de cinema 35mm dotada de um mecanismo de controle de exposição, análogo a um intervalômetro eletrônico, receber informações de um sensor de incidência luminosa proprietário destinado a confirmar a recepção de luz pelo conjunto ótico, gerenciar as tarefas e arquivos. Este software que atua entre os elementos COTS aglutinados ao sistema, desempenha também um papel de middleware. Ainda não existe e seria escrito, levando-se em consideração outros softwares presentes na máquina e os equipamentos combinados.

\subsubsection{Sensibilizando a Película}

Uma das partes mais delicadas do modelo é a na qual ocorre a sensibilização da película com a informação contida no intermediário digital, pois está sujeita aos mesmos tipos de desventuras e limitações que uma película na produção, quebras, riscos, poeira e exposição acidental do filme à luz. E a estes fatores somam-se os introduzidos pela combinação dos processos de exibição e de captura de imagens.

Neste módulo, temos a necessidade de um aparato de captura que funcione de maneira semelhante a uma câmera fotográfica controlada eletronicamente, disposta de um chassi em tamanho suficiente para acomodar a película 35mm usada no transfer e que depois de modificada, possa ser comandada pelo programa de controle de exposição. O conceito de tal câmera pode ser 
encontrado numa rostrum ${ }^{89}$ ou ainda nas câmeras cinematográficas capazes de realizar captura quadro a quadro - câmeras para animação.

Determinamos dois pontos de partida para a adaptação da câmera para captura e a escolha de um ou outro deve ser feita com base na relação custobenefício determinada na manufatura das peças de adaptação.

O primeiro deles considera a modificação de uma câmera fotográfica $35 \mathrm{~mm}$ convencional e a ela adiciona um adaptador para encaixar o chassi de filme $35 \mathrm{~mm}$, um dispositivo elétrico de avanço da película, dotado de interface com o sistema de controle e alguns sensores - incidência luminosa, próximo fotograma avançado etc... Apresenta a vantagem de partir de um aparato mais fácil de ser encontrado e de menor custo, uma câmera fotográfica $35 \mathrm{~mm}$, composta por um mecanismo menos complexo e com menor número de partes móveis. Uma desvantagem é o provável maior custo de manufatura dos adaptadores e a necessidade de alteração do mecanismo para a utilização de filmes mais longos que os $35 \mathrm{~mm}$ convencionais.

O segundo ponto, a câmera cinematográfica dotada de captura quadro a quadro, traz a grande vantagem de exigir uma menor adaptação eletromecânica, pois as modificações ocorreriam apenas para habilitá-la a receber comandos do sistema através de uma interface e instalação dos sensores, uma vez que estas câmeras possuem chassis para captura de filme de cinema em tamanho suficiente para o nosso uso. Como desvantagens devemos considerar a menor disponibilidade destes equipamentos, seu maior custo, maior complexidade do mecanismo e maior número de partes móveis.

Independentemente do ponto de partida, consideramos o resultado será o dispositivo receptor ótico, controlável, a ser combinado com o exibidor, que, em ordem de preferência, pode ser um monitor de computador à base de cristal líquido LCD, tubos de raios catódicos - CRT - ou projetor um que utilize tecnologia - digital light processor - DLPs. A seguir, apontamos as vantagens e desvantagens de cada um deles.

\footnotetext{
${ }^{89}$ Rostrum ou stand de animação era um equipamento utilizado na produção de animações em película cinematográfica onde uma câmera, capaz de capturar quadro a quadro, focalizava uma superfície móvel, onde se encontrava cada desenho.
} 
Os projetores DLP possuem uma excelente luminosidade, são capazes de, valendo-se de recursos ótico-eletrônicos, aumentar sua resolução nativa artificialmente, possuem uma boa relação de contraste e resultariam em um sistema de transfer mais rápido. As desvantagens estão não só nos elevados custos, mas na indisponibilidade de equipamentos na resolução WQXGA desejada, pois estes projetores destinam-se à geração de imagens de no máximo 1920x1080 pixels. Os hoje existentes dotados de maior resolução extrapolam o grupo de produtos COTS, pois não estão ao alcance do consumidor comum.

Os monitores CRT são ainda encontrados na resolução desejada e apresentam melhor reprodução de cores quando comparados aos LCDs, seu custo é menor do que os projetores DLP equivalentes. Contudo, são grandes as desvantagens, visto que a tecnologia já alcançou o ápice de seu desenvolvimento e vem sendo preterida em benefício de outras mais rentáveis ao fabricante, em especial o mais popular LCD. O CRT nem sempre apresenta distribuição homogênea da camada fluorescente, resultando, esporadicamente, em uma tela com ligeiras aberrações cromáticas. O feixe de elétrons não mantém a mesma característica de varredura e deflexão em função do desgaste dos componentes e a grade ou máscara pode gerar distorções se mal alinhada. As interferências magnéticas causam alterações cromáticas em muito maior escala que as outras tecnologias e campos contínuos causam danos permanentes à tela. $\mathrm{O}$ consumo quando comparado às outras tecnologias é bem mais elevado.

A tecnologia do display de cristal líquido vem recebendo investimentos consideráveis. Os monitores de LCD, que têm se desenvolvido significativamente, funcionam no princípio de luz valvulada. O LCD compreende um sanduíche de películas polarizadas, células de cristal líquido e uma matriz de Thin Film Transistor - TFT. Endereçando-se pela matriz, é possível alterar a corrente numa área desejada e, pela característica do cristal líquido combinado ao filme polarizado, bloquear a luz que por ali passaria. Na matriz ativa, O TFT retém o estado daquele pixel até o momento da próxima atualização. Os monitores de LCD vêm sendo produzidos cada vez em maior resolução, maior contraste, menor consumo e tempo de refresh. São tão contínuos os investimentos que a toshiba anunciou sua intenção de lançar, em meados de 2008, um monitor LCD de 3840 x 2800 pixels. As 
desvantagens do LCD são os dead pixels, regiões da matriz que não alteram o estado e a alteração cromática em função do ângulo de visão.

Ponderados estes fatores, consideramos que o monitor de LCD apresenta os maiores benefícios para o aparato, pois é encontrado na resolução WQXGA, é menos suscetível às alterações magnéticas, consome menos energia, há espaço para evolução da tecnologia e os custos são compatíveis com a filosofia do modelo.

\subsection{Os Módulos}

Discutidos estes principais pontos na definição do modelo, o próximo passo foi determinar a conectividade dos módulos imaginados e sua relação com o sistema como um todo para chegar a um fluxo de funcionamento compatível com as necessidades levantadas, sem extrapolar as fronteiras estabelecidas na premissa restrição a uma filosofia COTS.

Concluímos que se podem resolver as eventuais questões de comunicação entre os módulos adotando soluções de hardware, projetando e construindo pequenos dispositivos de interface eletrônica, e software, desenvolvendo controladores e interfaces com o usuário / técnico, numa espécie de middleware ${ }^{90}$ mais abrangente, que avança ao nível de hardware.

\footnotetext{
${ }^{90}$ Rigorosamente, omiddleware engloba apenas os softwares responsáveis pela comunicação entre componentes de um sistema. Aqui, numa flexibilização, estendemos o termo ao hardware.
} 


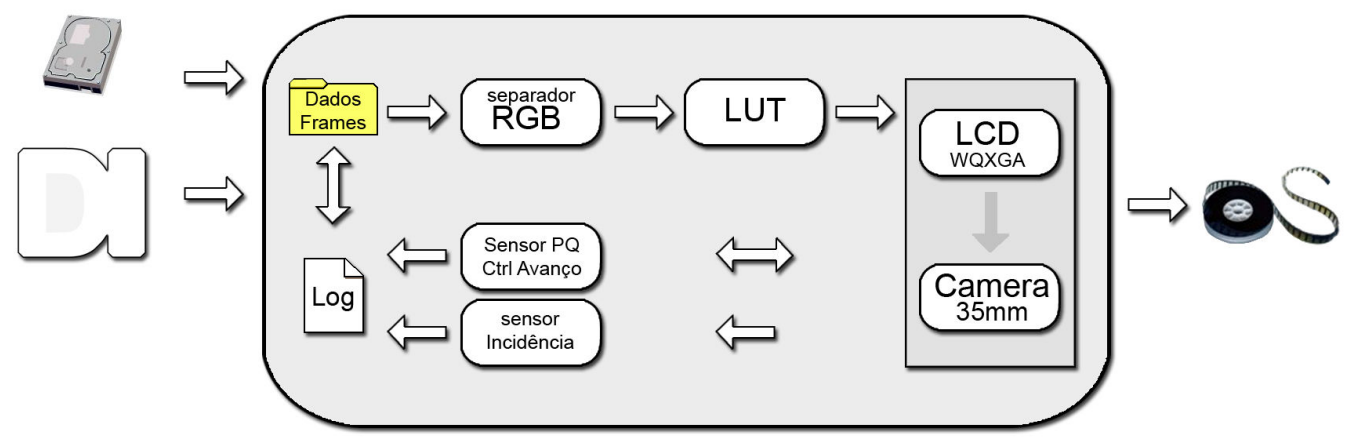

Figura 5.2 - Modelo Tecnologia Alternativa

O alinhamento do eixo ótico do módulo de captação com a normal do plano que encerra o LCD evita, não só a variação cromática indevida, como permite que não ocorram aberrações provocadas pelo keystone effect - uma distorção que ocorre ao se fotografar um plano em que a normal forma um ângulo não perpendicular com o eixo ótico da lente e produz imagens em formado trapezoidal.

A velocidade de transfer das imagens em $35 \mathrm{~mm}$ e capacidade de produção será derivada do tempo de captação de cada frame e não foi estimada, pois consideramos que os tempos de exposição podem variar significativamente em função dos equipamentos adotados na construção e integração dos módulos, invalidando as estimativas. Por conseguinte, não foram feitos cálculos neste sentido.

Prevemos que o melhor resultado de cor e contraste será conseguido pela tripla exposição para cada frame, uma para cada cor do sistema aditivo, ajustada pela LUT, pois, estimamos que desta maneira, o bloqueio da luz pelas células de cristal ocorrerá em maior grau, resultando em tons de preto mais escuros.

Ajustes no módulo emissor tais quais a regulagem de ganho, matiz, contraste e a própria composição da LUT devem ser realizados balizados por procedimentos empíricos de determinação dos valores, seguidos da avaliação e 
tabulação dos resultados de maneira a gerar as curvas de resposta e orientar as compensações de ganho ou exposição.

\subsection{Validade do Modelo}

Como estabelecemos na premissa, o intento deste modelo alternativo, em nenhum grau, pretende oferecer uma solução ao mercado high-end da indústria cinematográfica, uma vez que a qualidade da imagem sensibilizada pelo nosso aparato não apresentará os mesmos níveis de qualidade oferecidos pelos os modernos equipamentos para film transfer.

Acreditamos que sua maior utilidade será para o mercado independente, o pequeno produtor, o artista trabalhando com película e o estudante que, normalmente com orçamentos muito reduzidos, não conseguem arcar com os custos da produção de um filme em película. Não raro, de tão exíguas que são as verbas, apenas o custo de finalização em película $35 \mathrm{~mm}$ não cabe nos orçamentos, tornando os projetos inviáveis.

Não se sabe ao certo se, a médio ou longo prazo, o filme cinematográfico deixará de ocupar um lugar no seleto grupo das mídias exibidoras e, combalido, se juntará às chapas das lanternas mágicas, ao disco de vinil e ao laser-disc no grupo das mídias extintas. Fato é, que hoje, encontra-se ainda saudável e combatente.

Há mais de uma centena de festivais de cinema realizados anualmente e este modelo alternativo tem a capacidade de gerar filmes em película, em qualidade de imagem compatível com estes eventos. Conseqüente de seu extremo menor custo de implementação, quando comparado ao dos equipamentos profissionais utilizados na indústria cinematográfica, o custo operacional tende a ser, também, uma fração do praticado pelas empresas especializadas, permitindo uma maior base utilizadora. 


\section{Conclusões Finais}

As evoluções tecnológicas no cinema, bem como em qualquer área permeada de tecnologia, ocorre num processo contínuo, com a participação de múltiplos agentes, que muitas vezes sem perceber, acabam semeando as novas tecnologias que futuramente suplantaram as tradicionais. Este processo ocorre cada vez mais rapidamente e, conseqüentemente, as tecnologias e conhecimento de outrora, muitas vezes, deixam de ter importância para a indústria, caem em desuso.

A história da evolução dos equipamentos audiovisuais, seja na era précinema no século XIX ou no XX, é recheada de exemplos de desenvolvimentos colaborativos, aprimoramentos e por vezes descobertas paralelas simultâneas. Atribuir os avanços da arte cinematográfica a só um indivíduo, algo comumente encontrado em publicações, é uma prática que, no mínimo despreza o esforço dos muitos que colaboraram para a evolução da técnica e da arte.

A idéia de que não existe imagem em movimento é uma teoria que não encontra ampla ressonância entre os puristas, amantes da arte cinematográfica, mas que apresenta um frutífero campo para discussões. Ao reduzir o cinema a sua menor unidade, o quadro, podemos melhor entender a percepção de movimento e, partindo daí, repensar maneiras de reconstruí-lo.

A convergência é um processo que avança a cada dia e dificilmente será revertido. A internet, computadores, televisão, celulares, o vídeo e o cinema, caminham para, se não um suporte único, uma área comum onde o compartilhamento e a liberdade de formatos e suportes são a regra. $O$ custo decrescente dos equipamentos e programas de computador modifica as relações hierárquicas rígidas até então existente e vem dando lugar a um novo modelo, mais participativo.

Ao libertar-se dos seus átomos e tornar-se informação, bits manipuláveis, o audiovisual adquiriu uma flexibilidade sem precedentes. Os limites da matéria foram rompidos e com isso, cada vez mais, torna-se realidade a máxima de que o limitante é a imaginação do homem. 
Conhecer as tecnologias, técnicas e processos existentes nos ajuda a entender melhor as vindouras. As ferramentas digitais quando combinadas aos outros métodos existentes permitem-nos reduzir custos e muitas vezes tornar viáveis realizações de grande dificuldades.

Apesar de não existir consenso em sua definição, o cinema digital é uma realidade e, seja no modelo da $\mathrm{DCl}$ ou num esquema desregulado, começa a afetar as relações sociais e mesmo sem estar maduro, já sinaliza aos dominantes do mercado cinematográfico que as regras precisam de revisão. O que funcionava até aqui tende a não acontecer amanhã.

O cinema digital traz esperanças de um maior mercado exibidor, relações menos verticais na indústria, redução dos custos de material com qualidade profissional, consolidação e expansão de um mercado alternativo e surgimento de um maior número de realizadores. Há resistência daqueles que já estão estabelecidos em posições confortáveis e não se pode prever quando ocorrerão as alterações mais significativas na relação produtor, distribuidor, exibidor.

As previsões que envolvem tecnologia possuem um alto grau de incerteza, tecnologias que se diziam extintas permaneceram e outras que se acreditava dominariam o mercado não sobreviveram. Entretanto, dada a velocidade que as transformações ocorrem na era do digital, é fundamental conhecer os recursos disponíveis e adaptar-se constantemente.

Dos processos de produção cinematográfica disponíveis, o que utiliza o intermediário digital mostra-se vantajoso, dotado de grande flexibilidade e capacidade de economizar recursos. Tende a se tornar preponderante num futuro não muito distante, independentemente de que parte do planeta se encontre o realizador. Com a difusão da processo convencional de pós-produção, o processo clássico ficou em segundo plano, até que foi desamparecendo por completo, hoje dificilmente é encontrado. O intermediário digital promete fazer a mesma coisa com o convencional. É o que, atualmente, mantém a maior qualidade durante o processo e exportá-lo para diversos suportes não é tarefa difícil. Há consenso de que o DI não é apenas mais um recurso e sim uma evolução tecnológica duradoura. 
Blogs, vlogs, podcasts e meios de compartilhamento de vídeo, tais quais o youtube ou google-video, apontam um modelo de consumo onde o indivíduo é produtor e espectador ao mesmo tempo, em múltiplas relações simultâneas. Apesar de não haver ainda modelos de negócio consolidados nesta nova dinâmica, as iniciativas são as mais diversas e a resistência dos grandes exibidores começa a ser minada.

A película ainda é um formato saudável e robusto de exibição, presente em 95\% das salas de cinema do mundo. Apresenta alta qualidade de imagem e é comumente escolhida para servir de suporte à exibição dos produtos das grandes indústrias cinematográficas. Existe numa diversidade de formatos e sua união com o intermediário digital é bem recebida.

O data transfer é o processo que traz a obra cinematográfica em sua melhor qualidade, contudo, ainda não existem salas em número suficiente, nem infra estrutura de dados para a adoção da projeção digital exclusivamente. Os equipamentos ainda tem elevado custo e sua implantação caminha lentamente, apesar de existirem previsões de uma explosão na difusão deste tipo de cinema digital.

Há diversos equipamentos para film transfer, com variações de tecnologia, mas baseados no mesmo conceito: controlar a maneira que a luz atinge a película, pois independentemente do atual estágio da evolução digital, a película cinematográfica é o resultado de um processo fotoquímico. Este conceito também foi adotado na elaboração do nosso modelo de tecnologia alternativa.

Da discussão da compatibilização do color space da mídia digital, de resposta linear, e a da película, de resposta logarítmica, concluiu-se que a adoção de LUTs mostrava-se com solução viável e não degenerativa da imagem.

A premissa do modelo de tecnologia alternativa para o film transfer considerou que os produtores de poucos recursos perdem oportunidades de realização em película pela dificuldade de finalizar as mesmas e orientou sua solução para atender a solução de qualidade deste grupo. 
A filosofia adotada foi a de utilizar equipamentos classificados como de prateleira, COTS, e dentro destes limites, valendo-se de middlewares e outras adaptações, combinar equipamentos de maneira a produzir o resultado em sintonia com os objetivos da proposta.

O modelo proposto lança mão de um computador desktop de médio desempenho, com processador de núcleo duplo, uma solução RAID para armazenamento com proteção dos dados, um monitor de LCD de resolução WQXGA e uma câmera $35 \mathrm{~mm}$ modificada para ser integrada e comandada pelo sistema. A transferência é realizada a quadro a quadro e a película, ao fim do processo, pode ser revelada normalmente em laboratório cinematográfico.

Discutimos algumas técnicas e processos para realização cinematográfica e apontamos parte das vantagens de se trabalhar em uma linha que utilize o intermediário digital. Entretanto, uma vez que a evolução das tecnologias occre em passo acelerado, não há com garantir que as práticas sejam as mesmas amanhã. Um ponto em especial é um dos fatores considerados empecilhos para a difusão maior da solução, o dos diferentes formatos e da falta de compatibilidade entre as latitudes da imagem eletrônica com a em película. A questão continua sendo discutida e uma das possíveis soluções é a adoção de um formato de imagem que tenha maior latitude, de maneira a acomodar tanto o vídeo como o filme. Um forte candidato é o high dynamic range HDR que representa mesmo cores que não são perceptíveis.

Consideramos que o modelo de tecnologia alternativa para transfer é de moderada dificuldade de implementação e pode ser viabilizado numa equipe em parceria, de modo a combinar as diversas habilidades necessárias - noções de eletrônica, mecânica, cinema, programação e informática. 


\section{Referências Bibliograficas}

ALTON, J. Painting With Light. Berkeley, USA: University of California Press, 1995.

ARIJON, D. Grammar of the Film Language. Los Angeles, USA: Silman-James Press, 1991.

ARNHEIM, R. El Pensamiento Visual. Rivadavia, AR: Editorial Universitária de Buenos Aires, 1971.

ARNHEIM, R. Art and Visual Perception: A Psychology of the Creative Eye. Berkeley, USA: University of California Press, 2004.

BEACHAM, F. American Cinematographer Video Manual 2nd Edition. Hollywood, USA: A S C Holding Corp, 1994.

The Virtual Studio. American Cinematographer, Hollywood, USA: A S C Holding Corp, Dez 1996.

BRENDEL, H. The ARRI Companion to Digital Intermediate, Second Edition: Set. 2005. Disponível em: <http://www.arri.com/prod/digital/digital_systems/DIcompanion/index.html>. Acesso em: abr. 2006 (div)

COLLIER, M D. The IFILM Digital Video Filmmaker's Handbook. Los Angeles: Lone Eagle Publishing Company, 2001

COLTHEART, M. The Persistences of Vision. Philosophical Transactions of the Royal Society of London. Series B, Biological Sciences, Volume 290, Issue 1038, pp. 57-69, Jul. 1980.

DALY, T. Special Effects, Retouching and Restoration. Hove, UK: Rotovision, 2004.

DE LUCA, L. G. A. Cinema Digital: mudanças e transformações para um novo cinema. 2003. 306f. Tese ( Doutorado em Comunicação e Estética do Audiovisual), Escola de Comunicações e Artes, Universidade de São Paulo, 2003.

DO VALE, M. A. P. O Cinema Brasileiro na Era das Imagens Eletrônicas: uma possível miscigenação entre a linguagem do cinema e do vídeo nos filmes de Guel Arraes. 2005. 120f. Dissertação ( Mestrado em Comunicação e Estética do Audiovisual), Escola de Comunicações e Artes, Universidade de São Paulo, 2005.

GRUNNEWALD, J. L. A Idéia do Cinema: segundo sete autores famosos. Rio de Janeiro, Editora Civilização Brasileira, 1969. 
HAYASHI, S. O. A Técnica de Finalização Cinematográfica: tecnologia e processos laboratoriais. 2003. 95f. Dissertação (Mestrado em Comunicação e Estética do Audiovisual), Escola de Comunicações e Artes, Universidade de São Paulo, 2003.

HAYWARD, P.; WOLLEN, T. Future Visions: new technologies of the screen. London, UK: British Film Institute, 1993.

HIRATA FILHO, M. A Imagem Digital e o Cinema de ficção Contemporâneo: duas possibilidades estéticas a partir do dogma 95. 2004. 228f. Dissertação (Mestrado em Comunicação e Estética do Audiovisual), Escola de Comunicações e Artes, Universidade de São Paulo, 2004.

JAMES, J. Digital Intermediates for Film and Video. Oxford, UK: Focal Press, 2005.

KONIGSBERG, I. The Complete Film Dictionary. New York, USA: Meridian, 1989.

LEONE, E.; MOURÃO, M.D. Cinema e Montagem. São Paulo: Editora Atica, 1987.

LONG, B.; SCHENK, S. The Digital Filmmaking Handbook. Rockland, USA: Charles River Media, 2000.

MACIEL, K.; PARENTE, A. Redes Sensoriais: arte, ciência, tecnologia. Rio de Janeiro: Contra Capa, 2003.

MARTIN, M. A linguagem Cinematográfica. São Paulo: Editora Brasiliense, 1990.

MCALISTER, M. J. The Language of Visual Effects. Los Angeles, USA: Lone Eagle Publishing Company, 1993.

MORAES, R.B. Contribuição à Técnica de Kinescopia. 1997. 93f. Dissertação(Mestrado em Cinema), Escola de Comunicações e Artes, Universidade de São Paulo,1997.

MORETTI, M. A. M. Cinema Digital no Brasil: qual o estado dessa arte?. 2002. 113f. Dissertação (Mestrado em Comunicação e Estética do Audiovisual), Escola de Comunicações e Artes, Universidade de São Paulo, 2002

MUYBRIDGE, E. Horses and Animals in Motion. New York, USA: Dover Publications Inc., 1986

The Human Figure in Motion. New York, USA: Dover Publications Inc., 1989

NEGROPONTE, N. A Vida Digital. São Paulo: Companhia das Letras, 1995.

PISHER, B. Looking Forward to the Future of Film - American Cinematographer, Hollywood, USA: A S C Holding Corp, August 1994 
RUBIN, M. The Little Digital Video Book. Berkeley, USA: Peachpit Press, 2001

RYAN, R. American Cinematographer Manual 7th Edition. Hollywood, USA: A S C Holding Corp, 1993.

SADOUL, G. O Cinema: sua arte, sua técnica, sua economia 2ed. Rio de Janeiro: Editora da Casa do Estudante do Brasil, 1956.

SALT, B. Film Style \& Technology: History \& Analysis 2nd ed. London, UK: Starword, 1992.

SERRA, F. A Arte e a Técnica do Vídeo: do roteiro à edição. São Paulo: Summus, 1986.

SKLAR, R. Film: An International History of the Medium. New York, U.S.A.: Harry N Abrams Inc. 1993

TAUB, E. Gaffers, Grips and Best Boys: from producer-director to gaffer and computer special effects creator, a behind-the-scenes look at who does what in the making of a motion picture. Gordonsville, U.S.A: St. Martin's Griffin, 1995.

TAYLOR, R. The Encyclopedia of Animation Techniques. London, UK: Quarto Publishing, 2003.

VINTERBERG, T.; VON TRIER, L. Dogme 95: the vow of chastity. Disponível em: $<$ http://www.dogme95.dk/the_vow/vow.html $>$. Acesso em: 11 mar. 2006

WILSON, A. Cinema Workshop, fourth ed. Hollywood, USA: A S C Holding Corp, 1983.

WINSTON, B. Technologies of seeing. London, UK: British Film Institute, 1996

XAVIER, I. A Experiência do Cinema, antologia. Rio de Janeiro: Edições Graal, 1983.

YOUNGBLOOD, G. Expanded Cinema. New York, USA: E.P.Dutton \& co., 1970.

Artigos (White Paper)

APPELQUIST, G. How PHAME Motion Compensation Algorithms Work. Disponível em: $<$ http://www.digitalvision.se/downloads/white_phame_motion_compensation.htm>. Acesso em: dez. 2006.

. SD to 4k Image Processing \& Restoration. Disponível em:

$<$ http://www.digitalvision.se/downloads/white_papers/SDto4kImageProcessingandRestoration.pdf $>$. Acesso em: nov. 2006. 
CUFF, S. Bringing Film into the Digital Age: Optimizing the DI Workflow. Disponível em:

$<$ http://www.digitalvision.se/downloads/white_papers/white_simon_cuff_optimizing_di_workflow.pdf $>$. Acesso em: nov. 2006.

DA VINCI SYSTEMS. 2K PlusTM Data Sheet. Disponível em: $<$ http://www.geniusofdavinci.com/PDFs/Product\%20Specs/2K\%20Plus\%20specs_070505.pdf $>$. Acesso em: dez. 2006 (div).

DCI, The DCI Specification in a Post-production Workflow. Disponível em: $<$ http://www.filmlight.ltd.uk/documents/FL-GN-TN-0060-DigitalCinema.pdf $>$. Acesso em: mar. 2005 (div).

MAIER, S. ARRILASER Colormanagement for Video Look. Disponível em:

$<$ http://www.arri.com/infodown/other/ti/wp_colormanagement.pdf $>$. Acesso em: 11 mar. 2006.

\section{SHAW, K. From One Light to Final Grade: Colourist Terms and Workflows. Asia} Image, Jun. 2006. Disponível em:

$<$ http://www.digitalvision.se/downloads/white_papers/white_colourist_terms_and_workflows.pdf $>$. Acesso em: nov. 2006.

Glossary for Colourists. Disponível em: <http://www.finalcolor.com/glossary.htm>. Acesso em: jan. 2006.

The Need for Speed: Comparing the Performance of Colour Correction Systems Disponível em:

$<$ http://www.digitalvision.se/downloads/white_papers/white_kevin_shaw_need_for_speed.pdf $>$. Acesso em: nov. 2006.

Site: Celco Disponível em: <http://www.celco.com/Home.asp>. Acesso em: mar. 2005 (div).

Site: Cintel Disponível em: <http://www.cintel.co.uk>. Acesso em: mar. 2005 (div).

Site: Da Vinci Disponível em: < http://www.geniusofdavinci.com>. Acesso em: mar. 2005 (div).

Site: DCinema Today Disponível em: < http://www.dcinematoday.com/>. Acesso em: mar. 2005 (div).

Site: Deluxe Disponível em: <http://www.bydeluxe.com/>. Acesso em: mar. 2005 (div).

Site: Digital Praxis Disponível em: < http://www.digitalpraxis.net/index.html>. Acesso em: mar. 2005 (div).

Site: Digital Video Systems Disponível em: <http://www.dvs.de/>. Acesso em: nov. 2006 (div). 
Site: Digital Vision Disponível em: <http://www.digitalvision.se/>. Acesso em: mar. 2005 (div).

Site: Efilmtel Disponível em: <http://www.efilm.com/>. Acesso em: mar. 2005 (div).

Site: Film Light Disponível em: $<$ http://www.filmlight.ltd.uk/>. Acesso em: mar. 2005 (div).

Site: Lasergraphics: Motion Picture Film Recording Systems. Disponível em: $<$ http://www.lasergraphics.com/index.htm>. Acesso em: mar. 2005 (div).

Site: Piranha Cinema Disponível em: <http://www.ifx.com/>. Acesso em: mar. 2005 (div).

Site: Quantel Disponível em: <http://www.quantel.com/>. Acesso em: mar. 2005 (div). 


\section{Glossário}

$16 \times 9$ - Formato de tela retangular, normalmente utilizados nos HDTVs. Pode ser encontrado grafado na forma 1:1.77 ou 1.77 .

Academy Aperture - É o formato que foi padronizado pela Academy of Motion Picture Arts and Sciences, em 1932, e que apresenta 1.37 de aspect ratio. É por vezes confundido com o 1.33, pois as proporções são próximas.

ADC - Conversão de analógico para digital - Analog to Digital Conversion ou Converter.

AES/EBU - Nome informal do áudio digital estabelecido pelas organizações AES e EBU.

Alpha channel - canal alfa é uma informação codificada nos arquivos que pode ser usada para representar a transparência de um pixel. Normalmente as cores a 32 bits para cada pixel, usam 24 para o RGB e os 8 restantes para o alfa.

Anamorfic - Anamórfico - Sistema em que a imagem é apresentada distorcida, comprimida, no eixo x, o da largura, com o objetivo de registrar uma imagem com aspect ratio superior ao do suporte. No cinema derivou de um aparado da primeira guerra mundial utilizado para aumentar o campo de visão dos blindados. No processo anamórfico, a lente da câmera comprime a imagem na sua largura e registra um fotograma distorcido. Quando da projeção, a lente do projetor realiza a operação inversa e projeta a imagem em seu aspecto normal.

Artifacts - Elementos estranhos ou defeitos em uma imagem de vídeo.

Aspect Ratio - Relação de Aspecto - É um valor utilizado para designar a proporção da tela e origina-se da operação de divisão das dimensões da tela: largura dividida pela altura. $O$ negativo cinematográfico nos primórdios do cinema era projetado no formato 4:3 e sua cria, a televisão analógica, também apresenta as 
mesmas proporções. Há outras maneiras de se expressar a mesma proporção, também conhecida por formato, entre elas a $4 \times 3,1.33: 1$ que é obtida ao efetuar-se a conta ou ainda 1.33. Por exemplo, o 16x9 adotado pela HDTV pode também ser expressado como 1.77. Formato é freqüentemente usado como sinônimo de proporção.

Asynchronous - Assíncrono, sem sincronismo. No vídeo, um sinal é assíncrono quando não tem sincronismo com a referência local.

ATM - Asynchronous Transfer Mode - Modo de transferência assíncrono

Bandwidth - Largura de banda - É a capacidade de transmissão. Referese à largura do canal através do qual os dados são transmitidos.

Bit budget - espaço, em bits, disponível para gravação de um informação. Um CD, por exemplo, possui 700MB de bit budget, um DVD5 4.7GB

Bitola - É o termo que define a dimensão física da película fotográfica, sua largura. Aceita o uso como sinônimo de formato ie: filme $8 \mathrm{~mm}$, 35mm etc...

BMP - BitMaP, Formato de imagem em mapa de bits, raster, sem compressão.

Broadband - Genericamente banda larga, é a capacidade de operar freqüências maiores do que as usadas para comunicações de voz (mais altas do que $4 \mathrm{kHz}$ ) e transmitir maior mais rapidamente.

Buffer - 1. Circuito ou componente que isola um circuito elétrico do outro. 2. Dispositivo digital de armazenamento usado para compensar a diferenças no fluxo de transmissão. 3) área da memória alocada para cada dispositivo de entrada/ saída para armazenamento temporário de dados.

CCD - Charge coupled device - Dispositivo de captura que converte luz em sinal elétrico. É usado em câmeras e telecines como um mecanismo óptico de varredura.

Checksum - método para verificar a integridade de um arquivo, através de uma operação matemática. 
Chromakey - Substituir uma porção de um sinal de vídeo sobre outro; as áreas de sobreposição são definidas por uma gama de cor específica, que serve de referência para a substituição.

CIF - Common Image Format - Formato de Imagem Comum, bastante difundido, usado para trocar conteúdo

Clock - Relógio ou base de tempo 1) dispositivo de sincronismo interno. Os clocks são usados para sincronização de eventos, tais como acessos à memória, execução de instruções e no sincronismo da transmissão de dados. 2) Em um computador, a CPU usa um cristal de quartzo para gerar um sinal elétrico de freqüência uniforme, a partir do qual os pulsos digitais são criados e usados. 3) A velocidade do clock é medida em hertz, $\mathrm{Hz}$

Color Grading - Processo pelo qual se altera a cor de uma imagem, televisiva ou cinematográfica, seja por meios eletrônicos ou fotoquímicos. É um termo mais abrangente que o color timing e mais adequado para as referências as alterações em recursos digitais.

Color Timing - Marcação de Luz - Processo pelo qual se altera a cor de uma imagem cinematográfica por fotoquímicos. É um termo derivado da prática de se corrigir a exposição de uma foto, seu timing. Rigorosamente, aplica-se apenas às correções fotoquímicas na película, sendo que para as digitais o termo color grading mostra-se mais adequado.

Compressão - Compression - Processo normalmente usado para armazenar mais informação numa mesma área. Nele, algoritmos reduzem a informação matematicamente.

Display - tela ou periférico de exibição.

Field - Campo - É uma porção definida correspondente à metade da área de um frame, composta pelas linhas deste, amostradas de maneira intercalada (uma sim outra não). Há dois fields em um frame, o par e o impar, que contém respectivamente as linhas pares e as ímpares da imagem. O sistema de vídeo entrelaçado atualiza suas imagens field a field. 
Flat Screen Display - Display de tela plana - Telas planas dos receptores de TV, com pequena profundidade parecendo quadros de molduras.

Interlaced - Entrelaçada - é o tipo de varredura utilizado normalmente pela televisão analógica que, de maneira a produzir maior resolução temporal, atualizava de seus quadros campo a campo - fields. O caractere i é usado para representar a varredura entrelaçada.

NonLinear Editing, NLE, Edição Não Linear - sistema dotado de capacidade de acessar o material de forma aleatória e efetuar os cortes também de maneira aleatória.

NTSC - Sistema de televisão analógica utilizado por alguns sistemas de vídeo, em especial os Estados Unidos, que opera a 29,97 fps. entrelaçados. Comumente é referido como sistema de cor apenas e origina-se da sigla National Television System Committee.

Off-line Editing, Edição Off-line -- Método de edição que consiste em trabalhar com uma cópia em vídeo de menor resolução do material, com ela definir o corte final e depois, gerar o produto final usando arquivos de referência destes cortes, ie: EDL ou CutList, sobre o material original. Esta segunda etapa é denominada edição online.

PAL - Phase Alternation Line - - Sistema de televisão analógica utilizado por alguns sistemas de vídeo, em especial os Europa e Ásia, que opera a $25 \mathrm{fps}$. entrelaçados. O PAL-M, que é o utilizado no Brasil, utiliza os mesmos 29,97 fps do NTSC, mas com codificação de cor distinta.

Peltre - liga metálica, fosca, especialmente de estanho e chumbo, usada na fabricação de utensílios domésticos de antigamente.

Pixel -- Picture Element- Elemento de Imagem - Ponto - É o menor elemento de uma imagem e é comumente substituído pelo termo ponto. Uma imagem de 300 pixel é uma imagem de 300 pontos.

Progressive - Progressiava - É o tipo de varredura que atualiza os frames de maneira progressiva, uma a um. As linhas da imagem são atualizadas em 
seqüência. Inicialmente conhecida por varredura não entrelaçada. O caractere p é usado para representar a varredura progressiva.

Protocol - é o protocolo, normalmente de comunicação. O TCP-IP dos computadores é um dos muitos protocolos disponíveis.

pull-down - Método usado para converter filme a 24fps (fotogramas por segundo) em vídeo entrelaçado a 30fps.Cria frames fantasma pela repetição de determinados fields de maneira que sejam gerados 6 frames a cada segundo.

Resolution - Resolução - Talvez o termo com o uso menos rigoroso do jargão audiovisual. Uma vez que a imagem é a representação do espaço no tempo, tem pelo menos duas resoluções a primeira relativa ao espaço e a segunda ao tempo. Quando se lida com fotografia, uma única imagem raster, a representação só existe para um instante no tempo e podemos usar apenas uma de suas resoluções para defini-la. Contudo, para imagens representativas do movimento, o intervalo em que as imagens são amostradas é uma informação muito importante da resolução. A resolução deve ser observada de duas maneiras, a resolução estática (spatial resolution - resolução espacial) e a resolução dinâmica (temporal resolution resolução temporal). Grossamente, utiliza-se a contagem dos pixels de uma imagem para expressar sua resolução, ou seja, 640x480, 5 megapixel. Esta representação é válida para o arquivo da imagem, onde a resolução indicaria a quantidade de pontos da imagem armazenados, contudo, quando da sua visualização, esta indicação não é acertada. A resolução estática, ou espacial, da imagem é a maneira correta de representar sua visualização, pois se leva em conta a área junto com o número de pontos. Na diagramação eletrônica, o indicador é utilizado com mais rigor, uma vez que seu suporte, o papel, acomodará a imagem numa área determinada. $A$ resolução dinâmica, por sua vez, é a freqüência com que uma imagem é atualizada, ou amostrada, normalmente avaliada em fps, quadros por segundo ou imagens por segundo. Feitas estas observações, constatamos que a imagem do vídeo NTSC, por exemplo, possui uma resolução dinâmica maior que o cinema. Ao se assistir um vídeo, a imagem é atualizada 60 vezes por segundo - metade da imagem, o campo - e no cinema 48 vezes, sendo que cada quadro é exibido duas vezes, o que resulta em 24 atualizações por segundo. O vídeo ntsc possui resolução temporal maior que o cinema. Cada um dos quadros, ou seja a resolução estática ou espacial, possui 
cerca de 315 kilopixels para o vídeo NTSC e 9000 kilopixels para a projeção cinematográfica $35 \mathrm{~mm}$. Conseqüentemente, duas televisões de alta definição, HDTVs, terão resoluções diferentes quando em tamanhos distintos e a efetiva escolha é entre a tv de maior resolução ou a de maior tela.

SECAM - SEquentiel Couleur A Mémoire - Cores seqüenciais na memória - Padrão de sinal de vídeo Francês e da antiga Rússia.

Streaming Media - Conteúdo multimídia - do tipo vídeo, áudio ou animação - que, tal qual os sinais de tv que chegam da antena, é exibido direto da transmissão em rede, internet ou lan, sem que seja antes armazenado pelo receptor.

Widescreen - Popularmente conhecido por "tela retangular", ou ainda "mais larga", é a tela que apresenta um aspect ratio superior ao Academy. Ou seja, se a proporção da tela for superior a 1.37 , seu formato será widescreen. Alguns populares são o 16x9, Cinemascope (2.35) o 2k. 